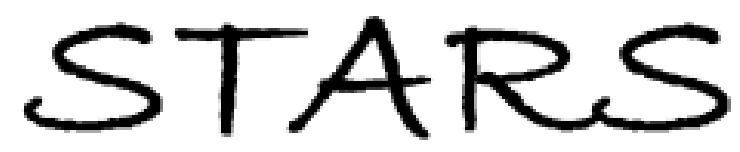

University of Central Florida

STARS

$1-1-1908$

\title{
A preliminary report on the underground water supply of Central Florida
}

E. H. Sellards

Find similar works at: https://stars.library.ucf.edu/cfm-texts

University of Central Florida Libraries http://library.ucf.edu

This Manuscript is brought to you for free and open access by the Central Florida Memory at STARS. It has been accepted for inclusion in Text Materials of Central Florida by an authorized administrator of STARS. For more information, please contact STARS@ucf.edu.

\section{Recommended Citation}

Sellards, E. H., "A preliminary report on the underground water supply of Central Florida" (1908). Text Materials of Central Florida. 87.

https://stars.library.ucf.edu/cfm-texts/87

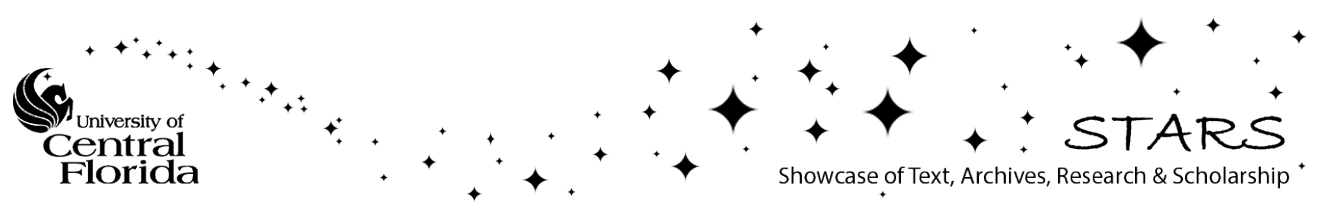




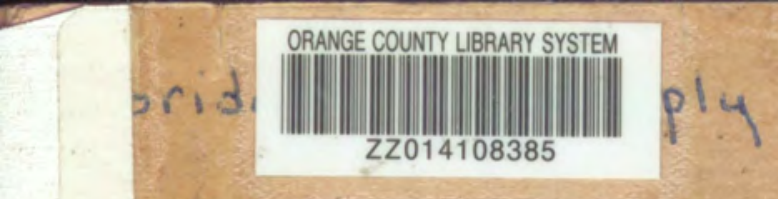

\title{
ALBERTSON PUPLIC LIBR
ORLANCO, FLORIDA
}

FLORIDA STATE GEOLOGICAL SURVEY

E. H. Sellards, state geologist

\author{
Bulletin No. 1
}

\section{A PRELIMINARY REPORT}

ON THE

\section{Underground Water Supply}

of

\section{Central Florida}




\section{ORLANDO PUBLIC LIBRARY SYSTEII}

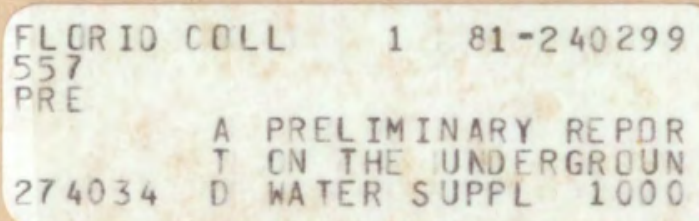


Mno. Atrov 19. Hhituran. 400 Sust Initral AntChlunds. flriva. 


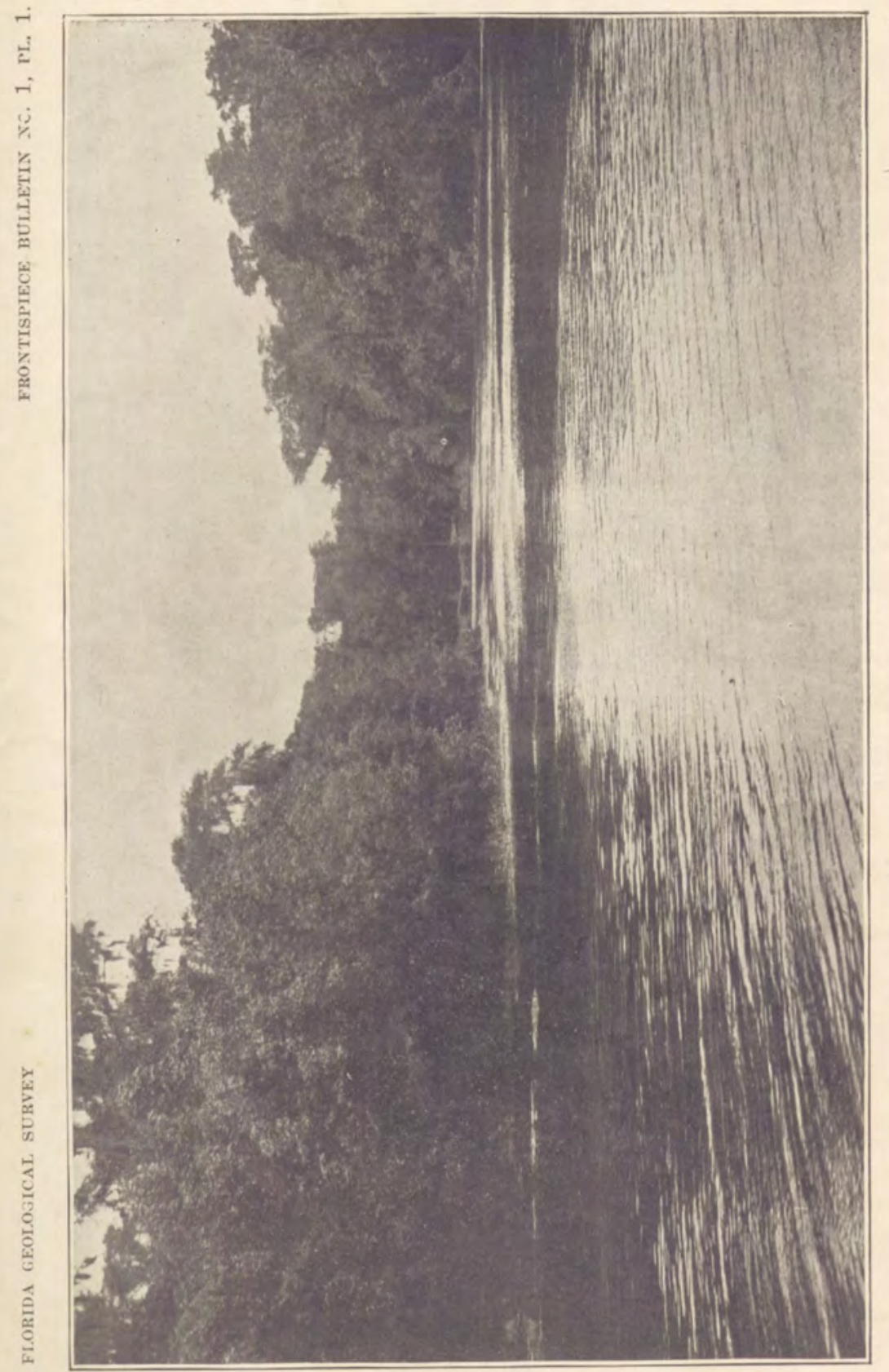

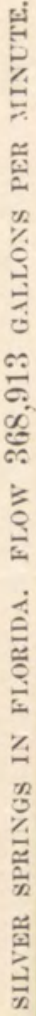


FLORIDA STATE GEOLOGICAL SURVEY

E. H. Sellards, state geologist

Bulletin No. 1

\section{A PRELIMINARY REPORT}

ON THE

\section{Underground Water Supply}

OF

\section{Central Florida}

BY

E. H. SELLARDS

Prepared in Co-operation with the United States Geological Survey.

Capital PUblishing Co., State Printer, Tallahassee, Fla.

खयक 


\section{LETTER OF TRANSMITTAL.}

To His Excellency, Hon. N. B. Broward,

Sir:-

Governor of Florida.

I have the honor to submit herewith for publication as Bulletin No. 1, of the Florida State Geological Survey, a rreliminary report of the underground water supply of central Florida. This bulletin has grown out of the co-operative investigations between the State and the National Surveys made in accordance with plans approved by you at the beginning of the year. The plan of co-operative work provides for an investigation of the water supply and of the general geology of the entire State. This preliminary bulletin is based upon the field work done by the State Survey during the fall of 1907 , and is issued at this time to meet the needs of the citizens of the State who desire the information obtained at as early a date as possible.

Respectfully,

E. H. SELLARDS,

State Geologist.

Tallahassee, Florida,

July $1,1908$. 


\section{CONTENTS.}

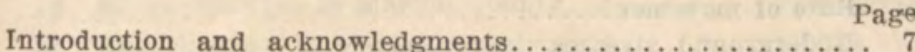

The area treated $\ldots \ldots \ldots \ldots \ldots \ldots \ldots \ldots \ldots \ldots \ldots \ldots \ldots, 8$

The topography of central Florida................ 9

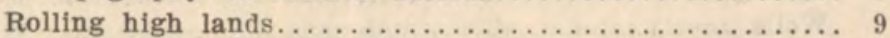

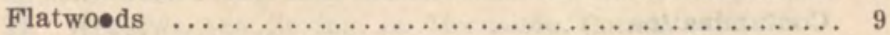

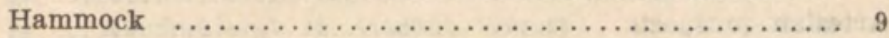

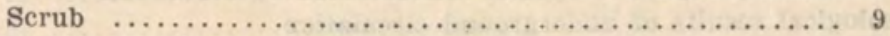

The geology of central Florida $\ldots \ldots \ldots \ldots \ldots \ldots \ldots \ldots \ldots \ldots$

Underground water: General discussion ............. 12

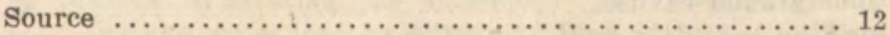

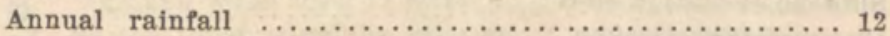

Disposition of rainfall ............................ 13

Water evaporated without entering the earth.......... 13

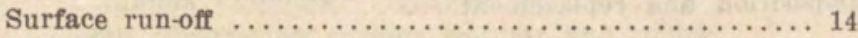

Rainfall entering the earth $\ldots \ldots \ldots \ldots \ldots \ldots \ldots \ldots \ldots \ldots \ldots \ldots \ldots \ldots$

Amount of water available for the underground supply..... 16

Underground circulation of water................. 17

Cause of movement $\ldots \ldots \ldots \ldots \ldots \ldots \ldots \ldots \ldots \ldots \ldots \ldots 17$

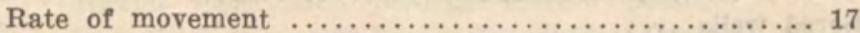

Porosity of the material....................... 18

Size of pores in water bearing medium............. 18

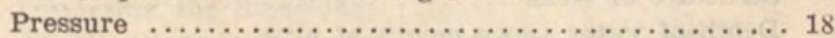

Temperature of the water.................... 18

Depth of underground water...................... 18

Hydrogen sulphide in underground water............. 19

Sulphur water not $\bullet$ vidence of beds of sulphur.......... 21

Sulphur deposits formed from hydrogen sulphide........ 21

Absence of hydrogen sulphide from certain waters in Fla... 22

Amount of hydrogen sulphide influenced by pressure..... 22

Underground water of central Florida................ 24

Water of the surface formations.................... 24

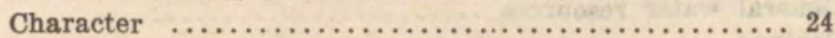

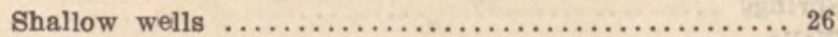

Contamination $\ldots \ldots \ldots \ldots \ldots \ldots \ldots \ldots \ldots \ldots \ldots \ldots \ldots \ldots$

Water of the deep formations.................... 27

Water of the Vicksburg Limestone.............. 27

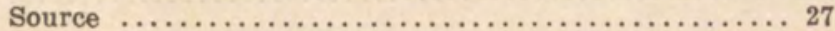

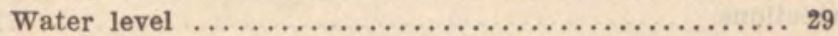

Quantity ..................................... 31

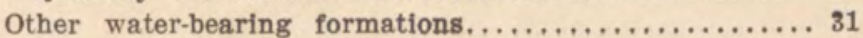


Quality of the water of the deep formations....

Movement of water of the deep formations............ 33

Direction of movement ..................... 34

Rate of movement........................ 34

Underground streams ...................... 34

Escape of water of the deep formations............... 35

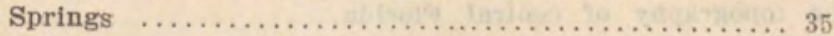

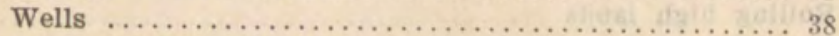

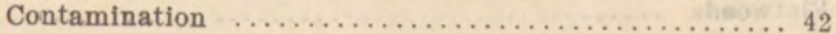

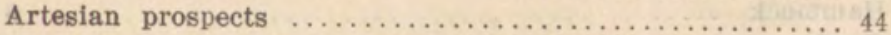

Geological results of underground circulation........... 46

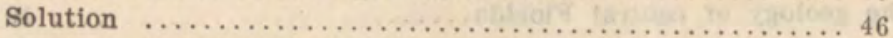

Amount of mineral solids removed ............... 47

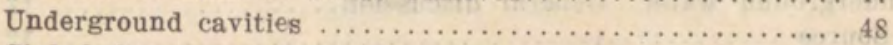

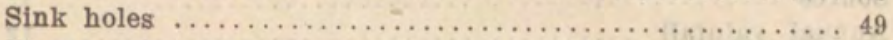

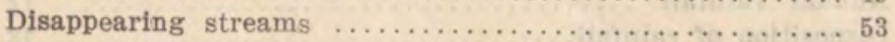

Solution basins $\ldots \ldots \ldots \ldots \ldots \ldots \ldots \ldots \ldots \ldots \ldots \ldots \ldots \ldots, 55$

Deposition and replacement.................... 56

Drainage of lakes, ponds and swamp lands by deep wells.... 58

Natural drainage wells........................ 58

Drainage of Lake Jackson ...................... 58

Drainage of Alachua Lake...................... 59

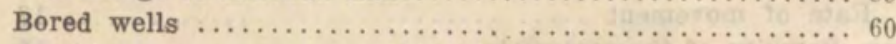

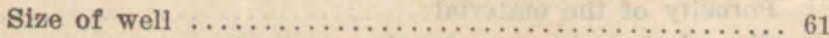

Structure of wells $\ldots \ldots \ldots \ldots \ldots \ldots \ldots \ldots \ldots \ldots \ldots, 61$

Depth of water above mouth of pipe............. 62

Distance from top of pipe to underground water 1evel, . 62

Drainage by wells at Orlando....................6. 62

Disposal of sewage by bored wells................. 64

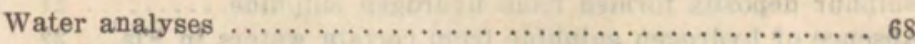

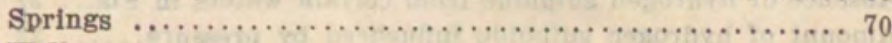

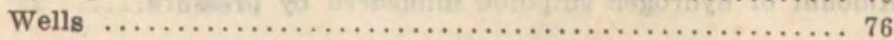

Water supply tables $\ldots \ldots \ldots \ldots \ldots \ldots \ldots \ldots \ldots \ldots \ldots, 83$

General water resources $\ldots \ldots \ldots \ldots \ldots \ldots \ldots \ldots \ldots \ldots, 83$

Springs $\ldots \ldots \ldots \ldots \ldots \ldots \ldots \ldots \ldots \ldots \ldots \ldots \ldots \ldots \ldots, 86$

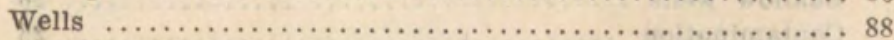

Public water supply $\ldots \ldots \ldots \ldots \ldots \ldots \ldots \ldots \ldots, \ldots \ldots, 94$

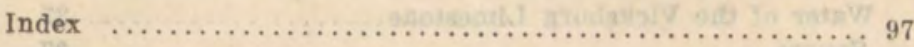

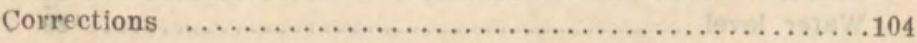


CONTENTS.

\section{ILLUSTRATIONS.}

Plates.

Facing page

I Silver Springs, in Marion County............. Frontispiece

II Blue Springs, in Marion County............. 38

III Map of area of artesian flow in Florida........ 44

IV Limestone sink near Sumterville, Sumter County 50

V Limestone sink near Sumterville, Sumter County 52

VI Weekiwachee Spring in Hernando County and Alachua sink in Alachua County............

Figures.

1 Sketch illustrating the relation of the under ground water level to Silver and Blue Springs.. Sketch illustrating the relation of underground water to surface contour in Suwannee and

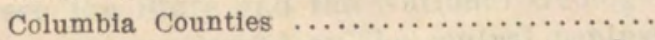

3 Sketch illustrating surface contour and underground water level through a part of Alachua

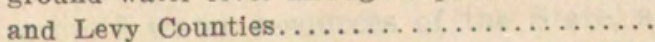

4 Sketch illustrating surface contour and underground water level through Marion County from Citra to a point four miles south of Ocala

5 Sketch illustrating the varying depth of wells

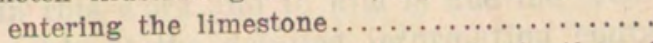

6. Sketch illustrating danger of contamination of a well by impure water entering through a

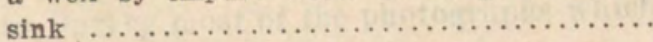




\title{
A PRELIMINARY REPORT ON THE UNDERGROUND WATER SUPPIY OF CENTRAL FLORIDA.
}

\author{
BY E. H. SELLARDS.
}

The study of the underground water supply of Florida was begun by the writer, while acting as field assistant to the United States Geological Survey in the summer of 1906. This work was interrupted on the part of the National Survey in November, 1906. During the winter of 1906 and 1907, however, it was continued by the writer, then acting as Geologist of the Florida State Experiment Station. A preliminary bulletin on the underground water supply of the State was published in March, 1907.* With the organization of the State Geological Survey this work was continued. Florida investigations were renewed by the National Survey in the fall of 1907 , and the work is now being carried on as co-operative work between the State and the National Geological Surveys. The report now issued on the central peninsular section is in the nature of a report of progress in the study of the underground water resources of the State, and is based upon the work of the State Survey during the fall season of 1907.

Mr. Herman Gunter has acted as the writer's assistant in this work and to him is due the credit of obtaining much of the detailed information contained in the water supply tables. Mr. E. Peck Greene has obtained for the Survey most of the photographs which accompany this bulletin.

The water analyses have been obtained from various sources, credit being given in connection with each analysis. A number of the samples have been analyzed in the laboratory of the U. S. Geological Survey, forming a part of the co-operative work between the State and the National Surveys. The Director of the State Agricultural Experiment Station has kindly supplied several analyses,

* Occurrence and Use of Artesian and Other Underground Water, Florida Agricultural Experiment Station. Bulletin 89. E. H. Sellards, Ph. D. 
while other analyses have been made especially for this report in the office of the State Chemist.

The writer is indebted to authors of a number of publications both of general and of special nature for data utilized in the preparation of this bulletin. Credit is given in the text wherever practicable. Among publications consulted relating especially to central Florida are the following: Water Supply and Irrigation Papers, U. S. Geological Survey, No. 102, 1904; No. 114, 1905; No. 149,1905 ; Bulletins U. S. Geological Survey No. 84 , 1892 ; No. 264, 1905; No. 298, 1906 ; Florida Agricultural Experiment Station, Bulletin No. 89, 1907. The reports on the underground water of the adjoining States of Alabama and Georgia, made by the respective State Surveys, have contributed to an understanding of the underground water conditions in Florida.

The thanks of the Survey are due to the many well drillers of the State who have kindly furnished data regarding wells drilled by them. To many well-owners, superintendents of city water supply, and other citizens, the Survey is likewise indebted for information and assistance.

It may be added that this publication is introductory and is not final, even for the limited area treated. Much detailed information that is desired is lacking. An important part of this information can be supplied in the course of time from well records and samples. Complete sets of samples from deep wells in various parts of the State will do much to determine doubtful questions of geological structure. The assistance of well drillers, which has been of much benefit in the past, will be appreciated in completing this data in the future.

\section{The Aren Treated.}

The area considered in detail in this bulletin comprises the following counties: Alachua, Columbia, Citrus, Hamilton, Hernando, Lake, Levy, Marion, Pasco, Sumter and Suwannee.* The section as a whole extends in a north and *For the location of these counties in the State, see map facing
page 44 . 
south direction a distance of about 175 miles from the northern line of the State, and is from 50 to 75 miles in width. The western boundary is formed by the Withlacoochee and Suwannee rivers and the Gulf coast. This section is the principal large area of peninsular Florida having Oligocene limestone at or near the surface. This limestone is best exposed in the central part of the area, although even here it is not continuously exposed, but is covered locally with irregularly deposited clays, and by a surface mantle of sand. To the south, east and north. the limestone disappears beneath later formations consisting of clays, shales, and limestones.

Topography of Central Peningular Florida.

In its general topography, central Florida is for the most part rolling. The topographic types may be grouped under the heads of rolling pine lands, flatwoods, hammocks, and scrub lands.

The rolling pine lands are underlaid by pervious deposits and are well drained. This type includes by far the largest part of this section. It is characterized by rounded hills and solution basins.

The term "flatwoods" is applied to the level section underlaid by impervious clay formations. These flatwoods are often partly covered with water during the rainy season and are popularly supposed to consist of low lands. There is, however, no necessary relation between surface elevation and this type $f$ land. Not infrequently flatwoods lie at the top of plateaus. This is the case in northeastern Alachua County, where flatwoods occur at an elevation of from 150 to 175 feet. Central west Alachua County, on the other hand, with an elevation of not more than 70 or 80 feet, consists of rolling pine lands.

The hammocks are underlaid, as a rule, by limestones and marls or other calcareous materials. The scrub growth occurs usually in deep sand, often covering low sand dunes.

In regard to surface elevation, much of this area lies below the hundred-foot contour line. With the exception of some of the hills, the greatest elevation reached within the area scarcely exceeds 200 feet. 


\section{Geology.}

The geology of the section treated in this bulletin will be given only in so far as is necessary to an understanding of the underground water conditions. A more detailed account of the geology is rendered unnecessary at this time by the fact that the State Survey will have for publication at an early date a special bulletin on the geology and stratigraphy of the State, the bulletin on this subject forming a part of the co-operative work between the State and the National Geological Surveys.

A thick limestone of Lower Oligocene age forms the foundation rock of the peninsula. This limestone is part of an extensive formation which reaches from Louisiana through southern Mississippi, Alabama and Georgia to Florida. It received in early publications the name of the Vicksburg Limestone from its typical exposure at Vicksburg, Mississippi. In character this limestone is, as a rule, soft and friable. It contains, however, large masses of flint, either irregularly bedded or occurring in the limestone as "horsebacks." These flint masses often form the backbone of local ridges and hills. This is due to the fact that the flint masses resist wear very much longer than the surrounding limestone, and hence stand ont as ridges. The thickness of this foundation limestone is undetermined. The most distinctive feature of this limestone is the abundance of Foraminifera occur. ring in it. The limestone, as typically developed, is in fact made up largely of the shells of Foraminifera, especially of the genus Orbitoides. Along with the Foraminifera occur many other marine invertebrates, among which bivalves, mollusks and corals predominate.

The formation known as the Ocala Limestone lies above the Vicksburg and resembles it in character. It has not been fully demonstrated that the Ocala Limestone may not be a local phase of the Vicksburg. As a matter of convenience the term "Vicksburg" as used in this report includes the Ocala Limestone.

These limestones form a mild anticline, the crest of which runs in a north and south direction through the center of the peninsula. The arch of this anticline rises 
from the west coast to the center of the State, the slope of the top surface not exceeding one or two feet per mile. From the broad top of the crest in the center of the State the limestone dips rapidly to the east. A similar, although less rapid dip occurs to the south. Well records have not been obtained in sufficient detail to determine whether or not the Vicksburg also dips to the north in north Columbia County. A mild dip in that direction is possible, although the limestone comes to the surface again in Georgia. The top surface of the limestone is irregular, due to erosion. It is difficult on this account to determine its dip even approximately. Moreover, it is unsafe to assume that the present surface slope of the Vicks. burg Limestone represents the dip of the formation. It is probable that erosion has been more rapid along the crest of the anticline than at the low lying and partly protected sides. The original dip may, therefore, have been somewhat greater than the present surface slope.

Following the formation of this basal limestone, a part at least of the area was sufficiently elevated to become dry land. The land as first formed appears to have been an island or chain of islands occupying central peninsular Florida, including probably parts of Columbia, Alachua, Levy, Marion, Sumter, Citrus and Hernando Counties. Subsequently marine deposits were formed around the edge of this land area, not only to the south and east, but also to the north and northwest. Upper Oligocene limestones, probably a northward extension of the Tampa Limestone, are reported from northern Columbia and Suwannee Counties." The Hawthorne formation of Upper Oligocene age occurs in northeast Alachua County, and to the south in Pasco County. Water-bearing Miocene beds follow the Oligocene and have been identified from east Alachua and Lake Counties. Pliocene clays occur irregularly over central Florida, lying usually beneath a surface deposit of sand probably of Pleistocene age.

*Dall, W. H.-Bull, U. S. Geol. Sur. 84, p. 121, 1892. 
UNDERGROUND WATER: GENERAL DISCUSSION.

Source.

Rainfall:-The chief source of underground water is the rainfall. Water vaporized through the energy of the sun passes into the atmosphere and is precipitated over the land as rain or condensed as dew or fog. The vapor is supplied to the atmosphere by evaporation, principally from the ocean, which, occupying three-fourths of the earth's surface, is continuously exposed to the sun's rays. To the vapor from the ocean is added that arising frem inland waters, from the dry land surface of the earth, and from the leaves of plants.

Other Sources:-The underground water depending directly upon the rainfall is added to by water escaping from streams during high water stages. The water in streams during flood seasons not infrequently rises above the water level of the surrounding country. In this case water escapes from the streams and joins the underground water supply. Springs which flow into the rivers may, during high water stages of the river, reverse their flow and conduct water with great rapidity into the underground water horizon. The amount thus added under the conditions existing in Florida is sometimes very considerable. This phenomenon is described in more detail in connection with some of the springs along the Suwannee River (p. 38).

Small additions to the underground water supply may come through any one of a number of other possible sources, but the total amount thus added is relatively small and may be omitted in a general discussion.*

\section{Annual Rainfall.}

The annual rainfall is the measure of the column of water that would accumulate at any spot in the course of a year, if all that falls should be preserved. The measure-

*A recent discussion of possible sources of underground water other than rainfall will be found in Bulletin 319, U. S. Geol. Sur., by M. L. Fuller. 
ment is commonly stated in inches. The average rainfall for the State as a whole for the fifteen years, from 1892 to 1906 , inclusive, as deduced from the U. S. Weather Reports, was 53.17 inches, annually. The year 1907 was a year of less than average rainfall, 49.15 inches, and if this year is included the average for the sixteen years, 1892 to 1907 , falls below 53 inches, being 52.92 inches. If longer periods be considered the variation from this average is not sufficient to materially change the result.

The average rainfall at Jacksonville for the 33 years ending with 1904, was 53.21 inches, annually; at Jupiter it was for the 17 years ending with $1904,59.19$ inches, annually; at Pensacola for the 25 years ending with 1904 , it was 56.33 inches, annually; at Tampa for the 15 years ending with 1904, it was 53.99 inches, annually; at Key West, the station of lowest rainfall, it was for the 34 years ending with 1904, 37.57 inches, annually.* The area covered by this bulletin lies in a part of the State supplied with about the average rainfall, and 53 inches may be safely assumed as a close approximation to the annual rainfall for this section.

\section{Disposition of RaINFall.}

Of the total rainfall of any area (1) a part is returned as vapor to the atmosphere without having entered the earth ; (2) a part is carried off by streams and rivers to the ocean without penetrating the earth; (3) a part is absorbed into the earth.

\section{(1) WATER EVAPORATED WITHOUT ENTERING THE EARTH.}

Immediately following a rain the atmosphere is nearly or quite saturated. The evaporation at this time is slow, and the part returned to the atmosphere directly from the land is an almost negligible amount. This is especially true of a soil into which the water enters quickly. Some of the water clinging to the leaves of plants is re-evaporated, as well as a part of that which falls into lakes, ponds, and temporary pools. While an estimate of the

*Deduced from the U. S. Weather Reports. Precipitation: Average, Greatest and Least Monthly Amounts, from the Establish. ment of Stations to the End of 1904. Wm. B. Stockman. 
amount evaporated must be regarded as only in the roughest way approximate, yet it is probably safe to assume that not more than 2 or 3 per cent of the total rainfall is returned to the atmosphere by direct evaporation with out having entered the earth.

\section{(2) SURFACE RUN-OFF.}

The relative proportion between the surface run-off and the surface in-take of water is dependent upon the character of the surface and the deeper formations and upon the topography. The former affects rapidity of in-take of water into the earth; the latter the rapidity of surface run-off.

With regard to topography, central Florida is either flat or rolling. Rarely can a locality within this section be described as hilly. The elevation increases gradually from sea level at the coast to a maximum of scarcely more than 200 feet inland, while large sections are so flat as to present no perceptible slope. Topographically the conditions are, therefore, very unfavorable to surface run-off.

On the other hand, the conditions are exceptionally favorable to large surface in-take. A mantle of sand, forming the surface deposit, is almost universally present. This sand receives the rainfall with great readiness. It is true that the sand is underlaid in certain limited areas of the flatwoods type, by a clay sub-stratum which, as a result of its impervious nature, checks the downward movement of water. For the most part, however, the underlying formation is either porous limestone, or a sandy pervious clay with the limestone just below. Locally, the sand may be largely absent, the impervious clay lying near the surface. From these localities and from other flatwoods come such surface run-off as this territory supplies. The flat woods country, however, is small in proportion to the combined extent of rolling pine, hammock, and serub lands.

The effect of these conditions on the drainage is very evident. Over considerable sections, involving in some cases whole counties, surface streams are entirely lack. ing. The large streams bordering or entering this section are supplied largely by springs, rather than by surface 
run-off. Wherever the Vicksburg or other porous limestone is the surface formation, or where it is covered only by a surface mantle of sand, or of sandy pervious clay, surface streams are absent, and surface run-off practically nothing. Such small surface streams as are formed, run often only a short distance, when they disappear through one of the numerous sinks, thus gaining entrance to the underground water horizon. Examples of these small disappearing streams are common to almost every section of inland Florida. They are described in more detail in the later pages of this bulletin.

It is sometimes estimated that in the presence of a sandy soil 3 to 4 per cent of the rainfall passes off as surface run-off. For the area treated in this bulletin having both a sandy soil and a pervious limestone sub-formation, the surface run-off probably does not exceed this amount.

\section{RAINFALL ENTERING THE EARTH.}

From the estimates already given, it would appear that approximately 95 per cent of the total rainfall over central Florida enters the earth. It will be recognized that as the geologic and topegraphic conditions vary from place to place, so will the relative proportion between surface run-off and surface in-take vary. Owing to certain conditions already specified, a few limited localities have a relatively high surface run-off.

Of the water which enters the earth a part is ultimately returned to the atmosphere by evaporation. The water retained in soils is slowly given up through evaporation during dry weather. As the evaporation takes place near the surface, capillary attraction draws a new supply from beneath, thus maintaining to some extent the moisture content of the soil. The amount of water thus brought. to the surface and evaporated, while varying with climate and with soils, is, in the course of a year, considerable.

To the evaporation from the surface of the soil must be added that from the leaves of plants. This in tura varies greatly with the different plants and with different climatic conditions. Kịng, in 1892, in one experiment, found that a crop of peas evaporated 477 pounds of water 
for each pound of dry matter formed, while corn under the same conditions evaporated in one instance 238 pounds of water per pound of dry matter. ${ }^{1}$ Assuming that a citrus tree evaporates approximately as much as the European oak (Quercus cerris), the water evaporated from the leaves of a fifteen vear-old orange tree is estimated by Hilgard at 20.000 pounds a year, or about 1,000 tons of water per acre of 100 trees.2 This is equivalent to about 9 inches annual rainfall over the same area. Water is the chief vehicle for conveying plant food absorbed from the soil by the roots. This enormous evaporation from the leaves is in part for the purpose of disposing of the water thus taken up by the plant. It serves chiefly, how. ever, the purpose of preventing, through the conversion of water into vapor, an injurious rise of temperature during the hot sunshine and dry weather.

It is impossible to estimate within even approximate limits the loss of water by evaporation from the surface of the ground, and from the leaves of plants in the area under consideration. The atmosphere in Florida is relatively humid. On the other hand, the temperature throughout most of the year is high. Much of the country is uncultivated, and practically all of the soil is of medium coarse texture.

It is probable that almost one-half of the rainfall entering the earth is re-evaporated from the surface of the ground and from the leaves of plants, and that not more than one-half of the total rainfall in Florida passes through the soil and surface material to join the underground water supply.

\section{Amount of Water Avatlable for the Underground} SUPply.

An annual rainfall of 53 inches is found by computa. tion to amount to $921,073,379$ gallons per square mile. Of this amount it is estimated that one-half, or $460,536,689$ '20th Ann. Report Wis. Agriculture Experiment Station,
p. 320, 1904.

${ }^{2}$ Based on weighings made by $R$. H. Loughridge of the leaves of a citrus tree at Riverside. Calif. Soils, by E. W. Hilgard, p. 263,
1906 . 
gallons per square mile, is added each year in central Florida to the underground water supply.

\section{Underground Circulation of Water.}

Underground water is found usually to be in motion, threading its way through pores, breaks, crevices, joints, and other openings in the rocks. Its movement is ordinarily slow and varies with different rocks and under different conditions.

\section{CAUSE OF MOVEMENT.}

The chief cause of movement of underground, as of surface water, is gravity. Capillarity is an additional force which under special conditions may become the controlling factor. The water returned to, and evaporated from the surface of the ground, as well as that carried to and evaporated from the leaves of plants, is moved by capillarity in opposition to gravity. Gravity, however, is the controlling force in the movement of water through the deep zones of the earth. Pressure, which is an important secondary cause of movement in the earth, is the expression of gravity. Except in the case of capillarity, the movement of water apparently in opposition to gravity, is, upon closer observation, found to be in reality, movement in response to gravity. The water which rises in a boring or flows from an artesian well or spring is forced up by pressure due principally to the weight of water lying at a higher level. The familiar observation that water seeks its own level has the same explanation.

\section{RATE OF MOVEMENT.}

The chief factors affecting the rate of movement of water through a porous medium as given by Schlichter are as follows :*

(1) Porosity of the material.

(2) Size of the pores in the water-bearing medium.

(3) Pressure.

(4) Temperature of the water.

*Water Supply Paper, U. S. Geol. Surv. No. 67, p. 17, 1902. 
(1) Rocks contain pores which, in the absence of a liquid, are ordinarily filled with air. The relative proportion of these spaces in the rock to the whole volume is the measure of the porosity. Thus if a cubic foot of sandstone will hold in its pores one-fourth cubic foot of water, its porosity is 25 per cent. The greater the porosity, the more water absorbed by the rocks.

(2) The size of the pores in the rock affects the rate of flow. Rocks having large pores receive and conduct water many times more rapidly than those having small pores.

(3) The greater the pressure, other conditions remaining the same, the more rapid the flow. A pressure of one pound per square inch is required to support each 2.31 feet of a column of distilled water at the temperature of 60 degrees $\mathrm{F}$. The weight of water from the deep zones is increased by solids in solution and in suspension, and is affected by changes in temperature. Something more than a hundred pounds pressure to the square inch is required to cause a flow from the bottom of a well 231 feet deep. Something more than 500 pounds pressure to the square inch is required to cause the rise of water in a boring a distance of 1150 feet. Pressure of this magnitude must materially assist in forcing water through the rock.

(4) The temperature of the water is found to influence the rate of flow. Schlichter finds that a change from 50 to 60 degrees $\mathrm{F}$. increases the capacity to transmit water under identical conditions by about 16 per cent.*

\section{Depth of Underground Water.}

The limit of the downward extent of water has not been reached by borings or tunnels, some of which exceed a mile in depth. Water, while thus known to penetrate to a depth greater than a mile, probably does not reach beyond five or six miles at the most. The movement, as has been stated, is through natural openings in the rock. Pressure increases in the earth with depth, and it is estimated that at a depth of approximately six miles, the

*Water Supply and Irrigation Paper. U., S. Geol. Sur. No. 140, p. 13,1905 . 
pressure is so great that the pores and eavities of even the strongest rocks, are completely closed.' making it impossible for water to penetrate beyond this depth. Most of the water, however, returns to the surface after a comparatively short underground course, only a small part of it reaching to this" great depth.

\section{Hydrogen Sulphide in Underground Water.}

The underground water of Florida is very generally impregnated with hydrogen sulphide $\left(\mathrm{H}_{2} \mathrm{~S}\right)$ also known as sulphuretted hydrogen, and hydro-sulphuric acid. Water containing hydrogen sulphide is commonly known as "sulphur water." Sulphur water is especially characteristic of the areas of artesian flow. In those sections in which open porous limestone is the surface formation, hydrogen sulphide is usually absent from the first water encoun. tered, although even here it is found to exist in the water from the deep wells, and in some springs.

Source:-Hydrogen sulphide may originate in nature in any one of several ways. The following have been suggested: (1) The decay of organic matter containing sulphur; (2) the reaction of organic matter upon sulphides or sulphates; (3) the reaction of acids upon sulphides; (4) partial oxidization of sulphides; (5) steam passing over sulphur.

The decay of organic matter is an obvious source of hydrogen sulphide in the underground water of Florida. Chemical analysis shows that sulphur is very generally present in Florida soils, ${ }^{2}$ and apparently invariably present in muck soils. Two samples of Florida peat which is, like muck, a vegetable accumulation, were found to contain .05 and .08 per cent of sulphur respectively. ${ }^{3}$ Hydrogen sulphide is formed in connection with the decay of eggs. In this case the albumen of the egg, according to 1896.

'L. M. Hoskins, 16th Ann. Rept. U. S. Geol. Sur., Part 1, p. 859, ${ }^{2}$ Bulletin 43 , Florida State Experiment Station, pp. 653,657 ,
659,1897 . 3 Bulletin U. S. G S. No. 332, page 77, 1908, Analysis of bog
sample from Orlando. 
Ostwald, contains the sulphur. ${ }^{1} \mathrm{H}_{2} \mathrm{~S}$ is also found escaping from sewer drains and cesspools, and is formed during the decomposition both of animal and vegetable substances. The $\mathrm{H}_{2} \mathrm{~S}$ occurring in shallow springs from marsh lands is doubtless supplied largely from organic material.

The sulphur in soils is probably, often present as sulphates. Thorpe states that the decay of organic matter in contact with sulphates results in the formation of $\mathrm{H}_{2} \mathrm{~S} .{ }^{2}$ The reaction in this case probably results from reducing properties of decaying organic matter, the sulphates being first reduced to sulphides according to the following reaction: $\mathrm{Na}_{2} \mathrm{SO}_{4}+\mathrm{C}_{2}$ (carbon of organic matter) $=2 \mathrm{CO}_{2}+\mathrm{Na}_{2} \mathrm{~S}$. The sulphide is then acted upon by the carbonic acid to form $\mathrm{H}_{22} \mathrm{~S}$ as follows: $\mathrm{Na}_{2} \mathrm{~S}+$ $\mathrm{H}_{2} \mathrm{CO}_{3}=\mathrm{H}_{2} \mathrm{~S}+\mathrm{Na}_{2} \mathrm{CO}_{3}$. The reaction of organic matter upon the sulphides is regarded by Van Hise as another important source of $\mathrm{H}_{2} \mathrm{~S}$ in underground water. ${ }^{3}$

The formation of hydrogen sulphide as a result of the action of acids upon metallic sulphides is one of the most familiar of laboratory experiments. This suggests the possibility of the formation of this gas as the result of the action of acids upon metallie sulphides contained in the rocks. Sulphides, especially those of iron, are widely scattered in the earth's crust and oceur in sufficient quantity to account for the formation of $\mathrm{H}_{2} \mathrm{~S}$ gas in water. Hydrogen sulphide is a weak acid and its salts are decomposed by a stronger acid. Sulphuric and other mineral acids should certainly react upon sulphides liberating $\mathrm{H}_{\frac{1}{2}} \mathrm{~S}$. Carbonic acid when abundant reacts upon alkali sulphides to produce hydrogen sulphide. It is true that the alkali sulphides are normally not abundant in the crust of the earth. Stokes has shown, however, that the reaction of sodium carbonate within the earth upon pyrite or marcasite produces sodium sulphide. The reaction given by him is as follows:

\footnotetext{
$8 \mathrm{FeS}_{2}+15 \mathrm{Na}_{2} \mathrm{CO}_{3}=4 \mathrm{Fe}_{2} \mathrm{O}_{3}+14 \mathrm{Na}_{2} \mathrm{~S}+\mathrm{Na}_{2} \mathrm{~S}_{2} \mathrm{O}_{3}+15 \mathrm{CO}_{2} \cdot{ }^{4}$

${ }^{1}$ Principles of Inorganic Chemistry, page 274, Ostwald, 1904.

2 Dictionary of Chemistry, Vol. III, p. $697,1900$.

${ }^{3}$ A Treatise on Metamorphism, Mon. XLVII U. S. Geol. Survey, page 1112, 1904.

4 From Van Hise, L. C. page 1107.
} 
It is a well-known fact that the carbon dioxide which unites with water to form carbonic acid is abundant in the deep waters, especially in the limestone formations, the pressure existing at considerable depth enabling the water to hold great quantities of carbonic acid. The series of reactions given by Stokes accounts for the presence of alkali sulphides in solution in the deep waters. It may be added that all sulphides are soluble to some extent in water, and in that condition may be acted upon by carbonic acid. ${ }^{1}$

The partial oxidation of sulphides is, according to Vau Hise, a possible additional method of the formation of hydrogen sulphide, the reaction being as follows: ${ }^{2}$

$$
3 \mathrm{FeS}_{2}+4 \mathrm{H}_{2} \mathrm{O}+4 \mathrm{O}=\mathrm{Fe}_{3} \mathrm{O}_{4}+4 \mathrm{H}_{2} \mathrm{~S}+2 \mathrm{SO}_{2} \text {. }
$$

The oxidizing processes are the most rapid near the surface, especially above the underground water level, and $\mathrm{H}_{2} \mathrm{~S}$ derived from this source probably supplies relatively shallow, rather than deep waters.

The formation of $\mathrm{H}_{2} \mathrm{~S}$ by steam passing over sulphur which occurs in connection with voleanoes, may be dismissed in considering the sulphur waters of Florida, since, as previously observed, Florida has no volcanoes and no indications of volcanic activity.

\section{Sulphur Water not Evidence of Beds of Sulphur.}

There is a widespread belief that the presence of sulphur water must necessarily indicate the existence of beds of the mineral sulphur. This conclusion does not follow. The probable sources of the sulphur in sulphur waters as indicated above is organie matter together with metallic sulphates and sulphides scattered through sedimentary rocks.

\section{Sulphur Deposits Formed from Hydrogen Sulphide.}

As stated in the last paragraph, sulphur waters are not to be regarded as resulting from beds of pure sulphur. On the contrary, it is probably true that these waters may, in

${ }^{1}$ Inorganic Chemistry. International Library of Technology. Sec. 12, p. 11.

${ }^{2}$ L. C. p. 1113. 
some instances, result in the formation of such deposits. Hydrogen sulphide when acted upon in the water by oxy. gen breaks up, forming water and sulphur, the reaction being $\mathrm{H}_{2} \mathrm{~S}+\mathrm{O}=\mathrm{H}_{2} \mathrm{O}+\mathrm{S}$. It is thus possible that $\mathrm{H}_{2} \mathrm{~S}$ in the underground water, or escaping from the underground water, may become dis-associated, forming deposits of pure sulphur. Such deposits of economic value have not been reported in Florida. It is a noteworthy fact, however, that one large mass of sulphur has been found underneath phosphate beds in Citrus County. The formation of this mass of sulphur is probably due to hydrogen sulphide.

Absence of Hydrogen Sulphide from Certain Waters in Florida.

The absence of hydrogen sulphide from the first water obtained from areas in which the open porous limestone is the surface formation, has already been stated. It is a well-known fact that if sulphur water is allowed to stand in the open air the gas will escape. This method of freeing water from an excess of $\mathrm{H}_{2} \mathrm{~S}$ gas is a common practice wherever sulphur water is used for domestic purposes. Wherever porous limestone lies at or near the surface th: sulphur gas which the water may have contained will find a ready means of escape. In other parts of the State where compact and impervious formations rest upon the limestone, the gas is prevented from escaping and sulphur water is obtained.

A mount of Hydrogen Sulphide Influenced by Pressure.

The quantity of $\mathrm{H}_{2} \mathrm{~S}$ gas which the water is able to hold in solution under these conditions, is determined by the pressure. The law of the solubility of gases in liquids is as follows: The quantity of the gas which a liquid is able to dissolve is directly proportional to the pressure on the gas. In the open, porous limestone with no confining stratum above, the water at the top of the underground water level is merely under atmospheric pressure. After passing the underground water level, however, the pres-

*First Annual Report, Florida State Geological Survey, 1908. 
sure increases rapidly. The increase of pressure is not simply that due to the atmosphere, but that due to the weight of the overlying column of water plus the atmosphere. According to Van Hise:" "The pressure which really is determinative as to the amount of gas which may be held in solution is that of a column of water extending to the free surface, plus the atmospheric pressure." From this law it follows that water at a great depth and under great pressure is capable of holding a large quantity of hydrogen sulphide in solution. When brought to the surface the pressure is relieved and the gas rapidly escapes. The artesian waters in the flowing areas of the State are under considerable pressure, thus enabling them to hold a large quantity of hydrogen sulphide as well as a high proportion of mineral solids in solution.

In order that the deep waters may hold large quantities of $\mathrm{H}_{2} \mathrm{~S}$ in solution it is necessary that the gas be available. This implies that the gas in the artesian and other deep waters originates at some considerable depth rather than at or near the surface.

*L. C., page 70 . 


\section{UNDERGROUND WATER OF CENTRAL FLORIDA.}

The underground water supply of central Florida available for general purposes may conveniently be discussed under the two divisions: (1) Water of the surface formations; (2) and water of the deep formations.

The water held in the interstices of the soil and other surface materials, while of great importance to the growth of vegetation, is not usually included in a consideration of the underground water for commercial and general purposes. Movement of water in soils is controlled by capillarity and this water is often referred to as "capillary" water of soils." Capillary water, although of great importance in soils, is not available as a source of supply for wells and will not be considered further in this report.

\section{Water of the Surface Formations.}

The water of the surface formations, often known as shallow or surface water, is that occurring nearest the surface and is available for shallow wells. The water in the surface formations is supplied by comparatively local rainfall. Its occurrence depends upon the permeability of the surface material and upon the existence of an impervious sub-stratum. The surface material may be made up of sand, sandy clay, or other porous substance. The impervious sub-stratum is usually a clay or shale. Both of these conditions are necessary. In the absence of an impervious sub-stratum the water entering the earth will pass through to a deeper mone. It is usually possible to determine from surrounding conditions the probability of the existence of water in the surface formations. Thus if in any locality the surface formation consists of sand or sandy porous clays underlaid by an impervious stratum of any kind, water may be expected. If, on the other hand, an impervious sub-stratum is absent, permitting the rainfall to pass directly into the deeper formations, water in the surface formations will be lacking.

CHARACTER OF THE WATER OF THE SURFACE FORMATIONS.

Owing to great variation in surface deposits from place to place, a similar variation in the character of the water 
must be expected. Thus, if the the surface formations consist largely of sand and clay with little or no calcareous material, the water may be expected to be soft, while if the surface material is highly calcareous the water is usually found to be hard. Since the water in the surface formations is supplied by local rainfall, it travels a comparatively short underground course, and its opportunity for taking mineral solids into solution is proportionately limited. The water from the surface formation is, in generai, characterized by a relatively small amount of total solids in solution. The following analyses may be taken as reprêsentative. These were made during 1900 by Professor A. W. Blair, Chemist of the Florida State Experiment Station, and have been kindly supplied by the Direetor:

\begin{tabular}{|c|c|c|c|c|c|c|}
\hline \multirow[t]{2}{*}{ Ingredients. } & \multicolumn{6}{|c|}{ Parts per Million. } \\
\hline & 1 & 2 & 3 & 4 & 5 & 6 \\
\hline Hardness . & 9. & 13.87 & 28.32 & 4.85 & 4.62 & 1.156 \\
\hline Chlorine ..... & 23. & 11. & 11. & 6. & 5.00 & 11. \\
\hline Nitrates ..... & .71 & .83 & 8.84 & .287 & .312 & 1. \\
\hline Nitrites .... & .0354 & .0306 & trace & none & none & none \\
\hline Free ammonia & .08 & .02 & .005 & .005 & .000 & .00 \\
\hline $\begin{array}{l}\text { lbuminoid } \\
\text { ammonia } . .\end{array}$ & none & .0114 & . 010 & none & .000 & .00 \\
\hline Total solids. & & 47. & 97. & 39. & 39. & 46. \\
\hline
\end{tabular}

No. 1. Water from pump at the Miller residence. Lake City, Columbia County.

No. 2. Water from Hensley place, Lake City.

No. 3. Water from pump on Perry's corner, Marion street, Lake City.

No. 4. Water from pump at Dormitory, Lake City.

No. 5. Water from pump at north end of Foster Hall, Lake City.

No. 6. Water from 30 -foot open dug well ending in clay, San Antonio, Pasco County. "Water clear, but containing brown-white sediment, floculent, slightly musty odor. On ignition residue blackened decidedly, indicating organic matter."

Escape of Water from the Surface Formations:-The water from the surface formations escapes principally through seepage and surface springs, and by percolation downward into the deeper formations. Some of it is drawn up again by capillary attraction into the unsaturated zone 
above, and some is absorbed by the roots of such plants as penetrate to this zone. The flow from the springs passes off into streams, some of it being evaporated into the atmosphere, while the remainder reaches the ocean. The water escaping downward supplies the deeper formations.

\section{SHALLOW WELLS.}

Water is obtained from the surface formations by shallow, dug, or driven wells. The water reaches these wells by seepage through the surrounding material, and is likely to vary in amount with the wetness and dryness of the seasons. This water is often desirable for boiler use owing to the small amount of encrusting material present. When, however, the water reaching the well passes through decaying vegetation or muck deposits, it usually contains acids which corrode the boilers. Shallow wells can not be relied upon as a rule for a large and unvarying supply of water. Only occasionally and under favorable conditions will they supply sufficient water for irrigating purposes.

Contamination:- When shallow wells are used as a supply for household purposes, the greatest care should be exereised to prevent contamination. The conditions under which this water occurs, render it readily susceptible to pollution. Such wells should never be placed near a baru or other outbuilding; nor should the offal from the house, or other organic material be thrown near them. The water, being supplied from the immediate surroundings, may carry impurities into the well. A well, for instance, passing through sand and terminating in an impervious clay gathers water from the surrounding area for a consid. erable distance. Many cases of typhoid fever have been traced directly to contaminated wells. The fact that the water has been used for many vears without fatal results does not preclude the possibility of infectious organisms finding their way into the well in the very near future. Nevertheless, when properly located, shallow wells often yield an excellent supply of soft, pure water.

Open dug wells are much more liable to contamination in this way than driven wells. The dug wells are often subject to overflow, thus admitting unfiltered surface water. 
Unless properly cemented they also receive water by seepage along the sides.

\section{The Water of the Deep Formations.}

When water is obtained in the deep formations it is, as a rule, more permanent and occurs in larger quantities than that in the surface formations. There may be more than one zone of deep water at any locality, depending upon the structure and arrangement of the underlying formations. . The term "deep water" is applied in this report to waters which are permanent and ordinarily inexhaustible by pumping, and which do not conform to local surface topography. This water is not necessarily obtained only at a great depth. In many cases the water level is near the surface. This is necessarily so since the surface descends gradually to sea level or to the springs which serve as an outlet for the deep waters.

WATER OF THE VICKSBURG LIMESTONE.

The Vicksburg Limestone is the most important waterbearing formation of central Florida. After passing through the surface deposits, wells throughout most of the section treated in this bulletin enter this formation. The thickness of the surface material and the depth to the limestone varies from a few feet of sand and soil in some localities, to several hundred feet in others. The area in which the limestone lies near the surface includes parts of Suwannee, Columbia, Alachua, Levy, Citrus, Sumter and Hernando Counties. The top of the limestone, however is everywhere extremely irregular. Occasionally wells within this section penetrate for a depth of one to two hundred feet before reaching the limestone. These places apparently mark the location either of the deep solution holes in the limestone, or of ancient valleys or basins subsequently filled by sand or clay.

Source.-The source of water in the Vicksburg limestone is the rainfall. This statement would scarcely call for further comment except for the fact that the abundance of water in the limestone and the conditions under which lit occurs have led to a widespread belief that the supply is replenished by underground streams from some 
deep or remote source. The conditions are most simple and the conclusion that the water in the limestone is supplied by rainfall is most obvious in those parts of the State in which the limestone lies near the surface. West central Alachua County serves admirably to illustrate the loeal origin of the water in the limestone. Throughout this area, surface clay deposits are either of but slight thickness, or entirely lacking, the limestone often approaching nearly or quite to the surface. Surface streams are absent, and practically the entire rainfall enters the earth. The ground water level (water line) in the limestone, lies at an average depth of from 30 to 40 feet. Numerous wells are put down in this section for the purpose of oblaining water for phosphate mining. The plan of construction of these wells affords an especially favorable opportunity for observing the effects of rainfall on the underground water. A large pit, ten to twenty feet in diameter is dug down to, or almost to, the ground water level. From the bottom of the pit a boring is put down until a sufficient supply of water is obtained. The pumps are lowered into the pit, thus enabling pumping by direct pressure. It is observed without exception that heavy and continued rains affect the water level. The effect, however, is not immediate as in the case of shallow wells ending in the surface formations. The rise in the water comes. s.owly, following the beginning of the rainy season some time being necessary for the downward percolation of the water. The highest level of the water table is reached some time after the close of the rainy season. That the change in the level is considerable is demonstrated by the fact that pumps lowered into the pits during the dry season may be under water by the close of the rainy season.

That the rainfall is the source of the water supply is less obvious although no less certain in those parts of the State in which later formations rest upon the Vicksburg Limestone. These later formations are often thin and pervious, permitting water to pass readily into the limestone beneath. Locally, impervious deposits occur which interfere with the downward passage of water. Under these conditions the water entering the surface is checked in its downward movement, but spreads horizontally, and may 
ultimately reach the limestone in any one of several ways. Such impervious deposits are often of local extent, and the lateral spread of the water may carry it beyond their border and into pervious material, thus permitting further downward movement. Occasional sinks formed in the manner described on a later page afford openings through the clay, permitting seepage water entering the sink to find a passage-way to the deeper formations. Not every sink, however, affords such a passage. Some, as elsewhere explained, become clogged at the bottom and remain filled with surface water.

Illustrations of surface water gaining direct entrance to the underground supply through sinks are too numerous to require special mention, as disappearing streams are common to all sections of the State in which sinks occur. Falling Creek and High Falls, in Columbia County, and Alachua Sink, in Alachua County, described on pages 54 and 56, serve as examples. Another illustration is found on the State University grounds at Gainesville. The greater part of the surface run-off from the University tract finds its way to a small stream which enters the hill near the south side of the grounds. In addition to the surface run-off, seepage water supplied by springs from the surface formations is also carried off through this stream. Apparently this stream formerly flowed to Lake Alice, and possibly at a still earlier stage to Hogtown Creek. The sink formed near the bed of the stream diverted it from its earlier course. An illustration of the sink which carries off the water received by seepage springs is afforded by the "Devil's Mill Hopper," near Gainesville. Florida. This sink is located on the highlands six miles northwest of Gainesville. The surface elevation at this place is about 180 feet above sea level. The sink, although of considerable denth, does not reach the deep water level. An opening at one side near the bottom. however, permits the escape of the water. The water from the surface and shallow formations enters this sink from a number of small springs around the sides, and reaches a deeper formation, the Vicksburg Limestone, through the opening at the bottom of the sink.

Water Level.- The water level in the limestone is ap- 
proximately uniform over considerable areas, its level being not materially affected by local changes in elevation. Otherwise expressed, the water level in the limestone is independent of local surface topography. This fact is illustrated by the deep wells at Gainesville. The records of these wells are as follows.

\begin{tabular}{|c|c|c|c|c|}
\hline of & $\begin{array}{l}\text { Location } \\
\text { from P.O. }\end{array}$ & $\begin{array}{r}\text { Surface } \\
\text { elevation } \\
\text { above sea. }\end{array}$ & $\begin{array}{l}\text { Water } \\
\text { level from } \\
\text { surface. }\end{array}$ & $\begin{array}{c}\text { Level of } \\
\text { water } \\
\text { above sea. }\end{array}$ \\
\hline $\begin{array}{l}\text { iamond Ice Co..3 } \\
\text { F. Williamson } 1 \\
\text { ty of Gain'ville } 2\end{array}$ & $\begin{array}{l}\mathrm{b} \\
\mathrm{m} \\
\mathrm{m}\end{array}$ & $\begin{array}{l}176 \mathrm{ft} . \\
180 \mathrm{ft} . \\
82 \mathrm{ft} .\end{array}$ & $\begin{array}{r}121 \\
128 \\
31 .\end{array}$ & \\
\hline
\end{tabular}

The measurements for both the surface level and the water level for the city well at Gainesville were made with care by City Engineer G. D. Cairns." The surface elevation of the other wells in the above table is taken from the topographic map of the Gainesville area. In estimating surface elevation from topographic maps, a limit of possible error of a few feet must be recognized. Moreover, the measurements to the water level were made in different years and at different seasons of the year. The variation with seasons in the water level amounts, as previously explained, in some sections, to several feet. In 1906 the writer made more exact measureinents for the U. S. Geological Survey at Orlando. These are reported in Bulletin 89 , of the Florida State Experiment Station, page 102, and are as follows:

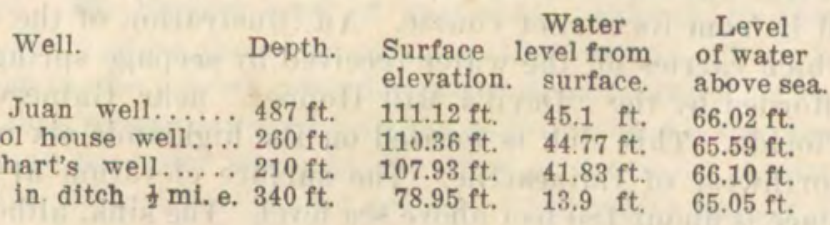

Factors Controlling the Water Level.-The controlling factors in determining the water level are location of outlet plus the friction of flow to that outlet. This is best shown by considering in some detail two of the largest springs. The following sketch is constructed with a view of showing the relation of the level of the underground water to ${ }^{*}$ Levels kindly supplied by B. F. Miller, Superintendent City
Water Supply. 
the level of the water in Silver Springs and Blue Springs, the two largest springs occurring in the State. The sketch represents a section from Silver Springs to Blue Springs in southwest Marion County, a total distance of 27 miles. The dotted line (2) represents the underground water level. The surface contour shown in the sketch is obtained from the topographic map of these sections and is drawn to scale. The line representing the underground water level is constructed from the well records. The water, as will be seen from the sketch, stands practically on a level with these two large springs. An apparent variation of a few feet in the records is within the limits of error since the elevation of both springs and wells are estimated from the topographic maps and since the measurements of depth to water in the wells were not all made at the same time, but at different seasons of the year. The sketch through Suwannee and Columbia Counties further illustrates the relation of outlet to water level. See fig. 1-2, p. 32 .

Quantity.-The quantity of water contained in the Vicksburg Limestone is large. The limestone is for the most part porous. In addition to the ordinary pore space in the rock, there are numerous solution cavities. The limestone is saturated by rainfall to the water level, and the supply which it contains is, for ordinary purposes, inexhaustible.

\section{OTHER WATER-BEARING FORMATIONS.}

The dip of the Vicksburg Limestone to the east and to the south carries it to such a depth that it is not reached by medium deep wells of northeast Alachua, east Marion, Lake, and parts of Pasco Counties. In these localities water is obtained from the Upper Oligocene and Miocene formations resting upon the Vicksburg. The water from these later formations contains, as a rule, a smaller proportion of solids in solution and is not so hard as that from the Vicksburg. 


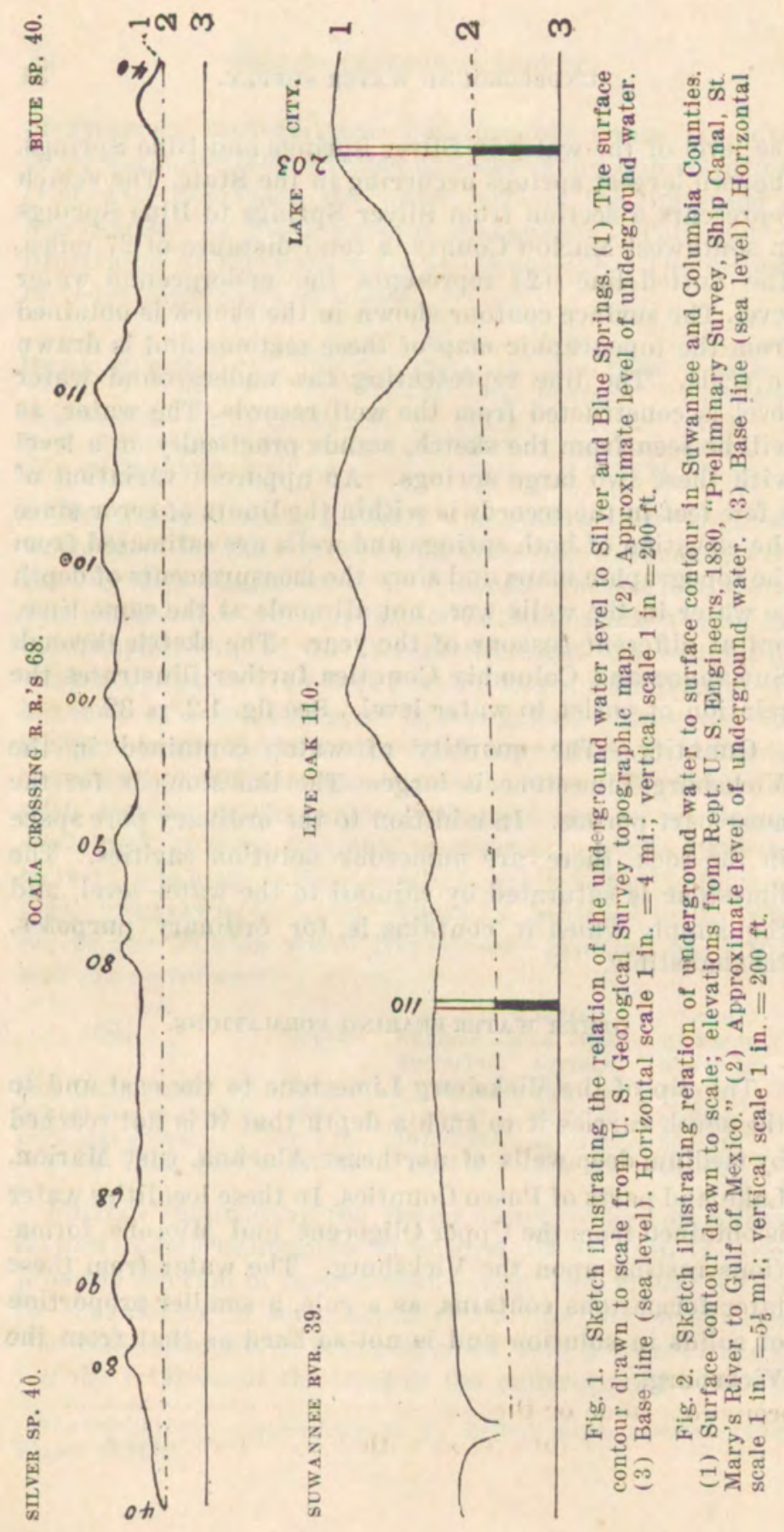


Quality of the Water of the Deep Formations.

Limestone water is usually hard; that is, it holds in solution certain salts, particularly salts of calcium and magnesium. The salts commonly present are the carbonates and sulphates. Calcium carbonate, $\mathrm{CaCO}_{3}$, while but slightly soluble in water, becomes in the presence of an excess of $\mathrm{CO}_{5}$, much more soluble, the salt being then held in solution in the form of bicarbonate $\mathrm{Ca}\left(\mathrm{HCO}_{3}\right)_{2}$. For boiler use softening of the limestone water by chemical treatment is often necessary. Numerous analyses are given preceding the tables of well records. From an examination of these it will be observed that the total solids, in a very general way and with occasional exceptions, increase with the depth of the well. The hardness of the water determined principally by the amount of calcium and magnesium salts present, also increases, as a rule, with depth. This increase in mineral solids in solution with depth is accounted for partly by the fact that the water from the deep wells has necessarily traveled a longer journey underground than has that of the less deep wells. In doing so it has had a greater opportunity to take solids into solution. Pressure, as elsewhere explained, is also an important factor. The amount of carbonic acid and other gases which the water can hold in solution is proportionate to the pressure, while the pressure, as elsewhere ex. plained, increases with depth.

\section{Movement of the Water in the Deep Formations.}

The heavy annual rainfall and the large surface in-take necessarily implies movement of the water in the limestone. The general direction of movement, it may safely be assumed, is from the central interior region toward the coast on either side. Locally the water is no doubt deflected from this general direction of flow. The rock through which the water moves is not of uniform texture. Local flint masses interfere with the flow. Water in one part of the formation may move readily through open porous limestone or through solution cavities. Elsewhere the movement is interfered with by compact areas such 
as occur irregularly in the limestone. Large springs through which the water finds an outlet draw upon the surrounding area, resulting in the convergence of the flow to the point of escape.

Information regarding the rate of movement is difficult to obtain. It is doubtless true that the rate of movement varies from place to place in accordance with the variation in the texture of the rocks, the proximity of springs, or other point of outlet, and the depth of the water in the earth. Such data as it has been possible to obtain indicate that, generally speaking, the water moves slowly through the many winding and inter-connecting solution cavities and through the porous rocks.

A considerable percentage of the wells drilled are reported to have encountered underground streams. The idea commonly conveyed by these reports is that these are streams in the ordinary sense of the term confined to definite channels and moving rapidiy through the earth. It is possible that variation in the texture of the rock may result in foreing the water through established channels forming locally underground streams. The number of such streams is, however, necessarily limited. If underground streams occurred as numerously as reports would imply, the total rainfall would be very quickly carried away and the streams cease to flow until the next season of heavy rains. The annual escape of water clearly can not exceed the annual in-take. If the water moved through the rock with a freedom approaching that with which surface water flows, it is obvious that the total rainfall would be quickly carried away, and the springs, instead of being perennial, would flow intermittently. Near the outlet of large springs the water doubtless moves in channels which become in reality underground streams. It is probable that the pressure to which underground water is usually subjected causing a vertical rise in the boring when the cavity is reached, is mistaken in many cases for the flow of a stream. 
Escape of Water of the Deep Formations.

SPRINGS.

The large annual in-take of water into the limestone continuing through a long period of time implies an equally ready escape. The natural outlet is through springs. These are extremely numerous in Florida and of unusual size. The list given in tabulated form on a later page includes the largest of those occurring in the counties covered by this report.

In addition to these, numerous large springs come up in the ocean, while many others occur along the sides and in the channels of rivers, bordering or entering this section, or in swamps or lakes under such conditions that an estimate of the flow is difficult or impossible. The most important of these rivers are the Suwannee, Santa Fe, Withlacoochee, and Ocklawaha, all of which receive a considerable part of their supply from springs.

The view is occasionally expressed that the large springs are fed by underground streams that originate in some remote section and flow at a great depth; and that the springs do not serve as an outlet for the local underground water supply, and are not affected by rainfall. Silver Spring (the largest of these springs), was closely observed by the writer during the first half of July, 1906. The rainfall during this month was unusually heavy, amounting for the first seventeen days of the month to 10.27 inches.* The water level in Silver Spring rose steadily, the total rise during this half month of reavy rains amounting to a little more than one half foot (.65 feet). The rise in the spring: does not follow immediately upon the rains. The greatest advance is observed a day or two after the heavy rains, indicating that some days are required for the water to percolate through the overlying rocks and to reach the springs. Neither is the spring made turbid by the rains since the water flltering through the sand and rock is freed from clayey sediment. A similar variation

*Data on rainfall kindly supplied by W. L. Jewett, recorder of the Ocala Weather Bureau Station. 
in water level in wells with the rainy season has been described on a previous page.

The area of drainage of each spring can not be closely outlined. The circulation of underground water is so complicated, and affected by so many factors that it is impossible to determine from just how large an area a spring draws. So far as amount of rainfall is concerned, a com. paratively small area would supply each of the springs. On the basis of estimates already given the in-take of a surrounding area of 421 square miles, or about onefourth of Marion County, is sufficient to supply the flow of Silver Springs, while a smaller area would supply each of the other springs listed. The fact that the springs are not affected more decidedly by the seasons is due to the slowness with which water percolates through the overly. ing rock or moves through the deeper zones. This slow movement results in distributing the total flow with approximate uniformity throughout the year.

These and other observations establish the fact that the springs receive their water supply from the rainfall of the surrounding country.

Silver Spring may be taken as typical of the limestone water springs of Florida. The basin of the spring has a depth of from 30 to 36 feet, with a total flow from several vents estimated at 368,913 gallons per minute. Professor John Le Conte visited this spring in 1859 for the purpose of studying its optical phenomena. With regard to the spring he says:*

"The most remarkable and interesting phenomena presented by this spring, is the truly extraordinary transpareney of the water; in this respect surpassing anything which can be imag. ined. All of the intrinsic beauties which invest it, as well as the wonderful optical properties which popular repoits have ascribed to its waters, are directly or indirectly referable to their almost perfectly diaphaniety. On a clear and calm day, after the sun has obtained sufficient altitude, the view from the side of a small boat floating on the surface of the water near the center of the head-spring, is beautiful

*Amer. Journ. Sci., Vol. XXXI, p. 3, 1861. 
beyond description, and well calculated to produce a powerful impression upon the imagination. Every feature and confguration of the bottom of this gigantic basin is as distinetly visible as if the water was removed, and atmosphere substituted in its place!"

"My observations were made about noon, on the 17th and again on the 20th of December, 1859. The sunlight illuminated the sides and bottom of this remarkable pool as brilliantly as if nothing obstructed the light. The shadows of our little boat, of our overhanging heads and hats, of projecting crags and logs, of the surrounding forest, and of the vegetation at the bottom, were distinctly and sharply defined; while the constant waving of the slender and delicate moss-like algae, by means of the currents created by the boiling up of the water, and the swimming of numerous fish above this miniature subaqueous forest, imparted a living reality to the scene which can never be forgotten. And if we add to this picture, already sufficiently striking, that objects beneath the surface of the water, when viewed obliquely, were fringed with the prismatic hues, we shall cease to be surprised at the myst-rious phenomena with which vivid imaginations have invested this enchanting spring, as well as at the inaccuracies which have been perpetuated iu relation to the wonderful properties of its waters. On a bright day, the beholder seems to ve looking down from some lofty airy point on a truly fairy scene in the immense basin beneath him, a scene whose beauty and magical effect is vastly enhanced by the chromatic tints with which it is invested."

The prismatic hues seen in this and other clear water springs of Florida, Professor LeConte believes to be due to the refraction of light passing through the water. He finds that white objects on a dark background when im. mersed in the water are fringed with blue at the top and orange and red at the bottom, while the color of the fringing is reversed for dark objects on a white background. The remarkable transparency of the Florida springs, due principally to the fact that the water has been filtered and decolorized in its passage through beds of sand, is probably augmented, in the opinion of LeConte, by the lime in solution in the water.

Among other springs resembling Silver spring in the manner of emergence, and in the mineral character and 
clearness of the water may be mentioned: Blue Spring in Marion County; Ichatucknee, Spring in Columbia County; Blue, Wekiva, and Manatee Springs in Levy County, Crystal River and Chesehouiska Springs in Citrus County; Weekiwachee Spring in Hernando County, and Newland Spring in Suwannee County. These springs form the source of streams, many of which, as in the case of Silver Spring, are navigable to the source. Newland Spring is exceptional in the fact that the water coming up as a boil from a circular depression or sink, after flowing as a stream for a distance of about 200 yards, again disappears into the earth. This spring is distant only about three miles from the Suwannee River. The static head of the underground water in the vicinity of Newlanil Spring is affected by the river. During high water stages the river frequently rises above the water level in the surrounding limestone. At this time the flow of the Newland Spring is reversed, the water then rising in the sink in which it ordinarily disappears and disappearing through the sink from which under ordinary conditions it rises.

The water of White Sulphur Spring and Suwannee Sulphur Spring is impregnated with hydrogen sulphide gas. Perrian or Salt Spring, in Marion county, is exceptional in the high proportion of solids, particularly of chlorides, which it carries.

WELLS.

In locating wells in the limestone area two distinct points should be considered: First, the depth at which a sufficient water supply is likely to be obtained; and second, the level at which the water, when obtained, will stand in the boring.

Level at Which Water Will stand in Completed Boring:-The distance that water may be expected to stand from the surface in the completed boring is a matter of more importance than the depth of the boring; for, while the expense of the boring terminates with the initial cost, the expense of lifting the water to the surface con- 


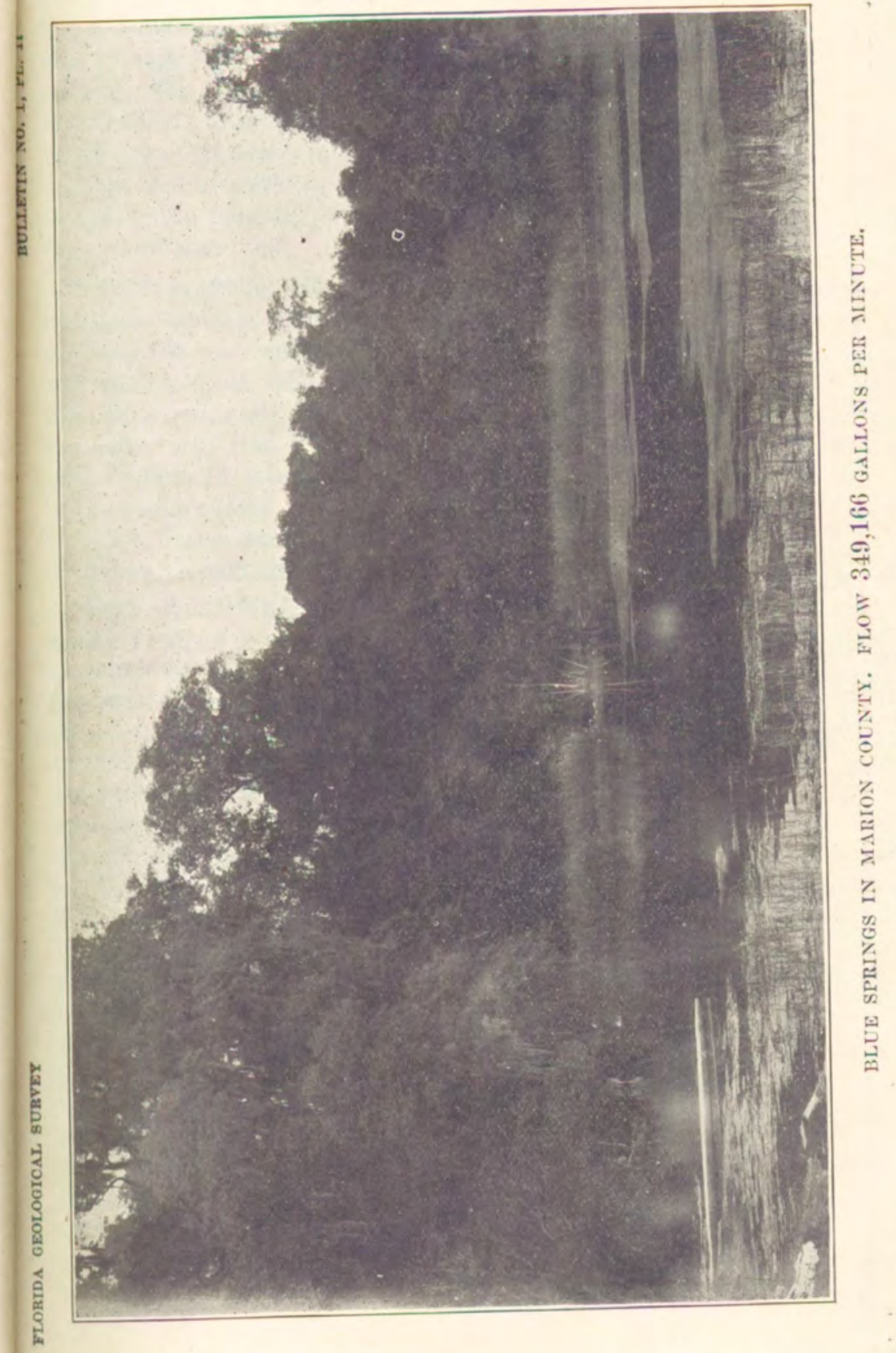


tinues indefinitely. If it is known that the water will rise near enough to the surface to admit of pumping by direct pressure, the cost of pumping is greatly reduced. The practicability of using water for irrigating purposes often turns upon this point, and in any case each additional foot that the water must be lifted involves an additional cost. In short, the expense of water is largely determined by the cost of pumping.

The tables giving the general water resources, and listing typical wells for each county, togetherwith the sketches showing the underground level in several of the counties will enable those who wish to put down wells to determine approximately in most cases how near to the surface the water will rise. The water level in the limestone as indicated above (p.30) does not conform to local variations in the surface level, but on the contrary, stands at a practically uniform level over considerable areas, regardless of surface topography. (See figures pp. 32 and 40.)

Depth of Boring.-In the Florida limestone the depth necessary to go to obtain water cannot be determined from surrounding wells. Ordinarily some water is obtained immediately upon passing the water line. For large quantities of water, however, it is usually necessary to penetrate the limestone until a cavity of some considerable size and extent is encountered. The effect of the cavity is apparently to serve practically as a collecting basin. Al. though not enough water to supply the pump enters the small boring by seepage, yet when the boring is connected with the very much larger opening of the cavity or solution channel, this larger collecting area is sufficient to afford a practically inexhaustible supply of water. Porous lavers as well as cavities are of irregular occurrence. Wells may be located within a few feet of each other and yet differ greatly in depth. The varying depth is illustrated by the Orlando wells. The four wells at the "sink" one mile east of Orlando reached a water cavity at the depth of 140 feet. The well in the "ditch," one-half mile to the west, starting at approximately the same surface level, encountered no cavity of appreciable size, but reached, at 


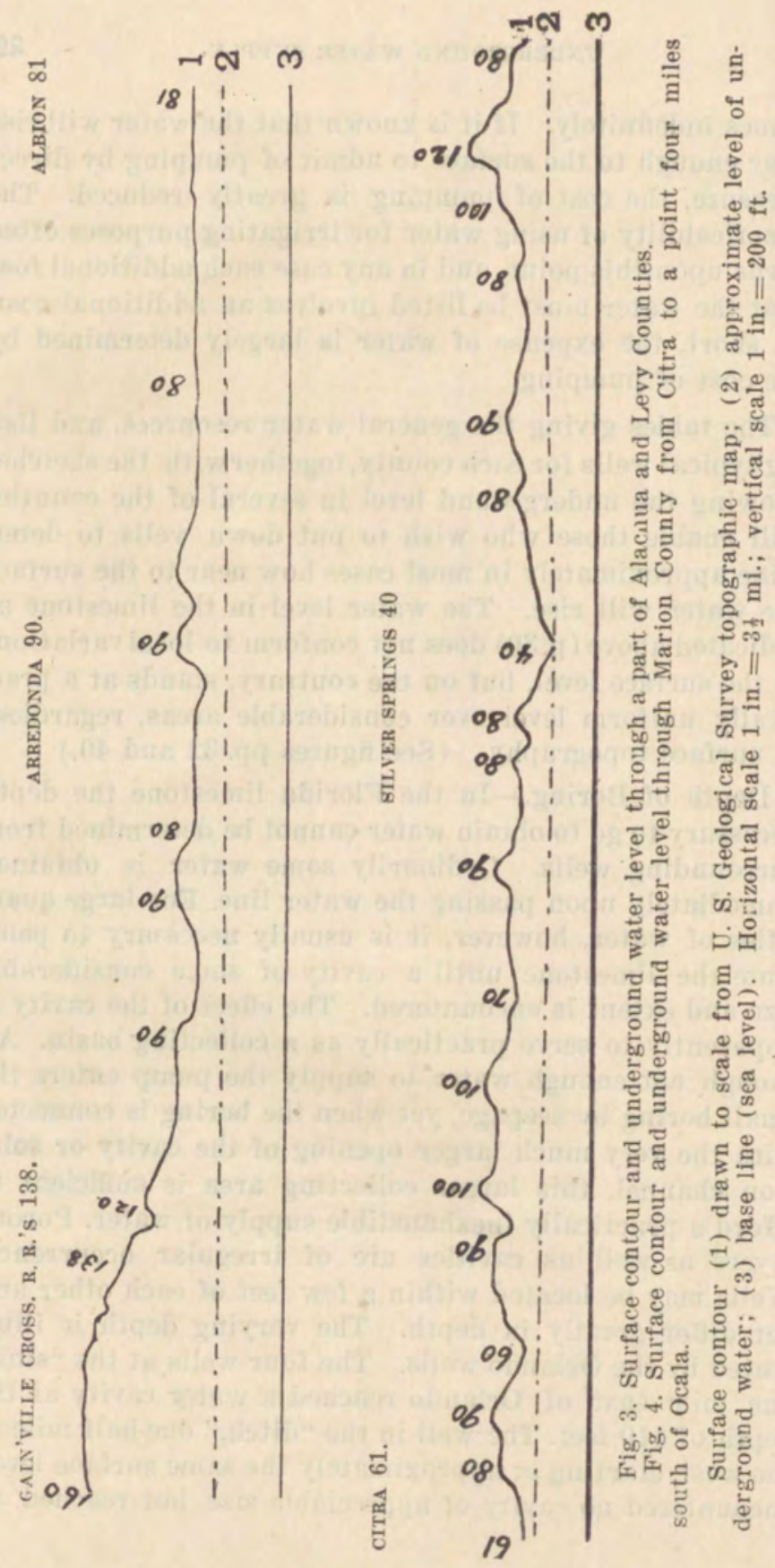


the depth of 340 feet, a porous layer with an abundance of water. The "school house well," the surface level of which is approximately 31 feet higher than that of the well at the ditch, entered a porous water bearing layer at a depth of 260 feet. The "San Juan" well, less than one-fourth mile to the northwest of the school house well, was put down to a depth of 487 feet before reaching a layer considered sufficiently open. The "Lockhart" well, one-half mile west of town, terminates in a cavity at a depth of 210 feet. The static head of the water obtained in these wells is practically the same for all (p.30). Another striking illustration of varying depth is afforded by the two wells at the Marion Farms, near Ocala. These wells are not more than six feet apart. One of them goes to a depth of 140 feet, while in the other it was necessary to go 175 feet in order to obtain sufficient water.

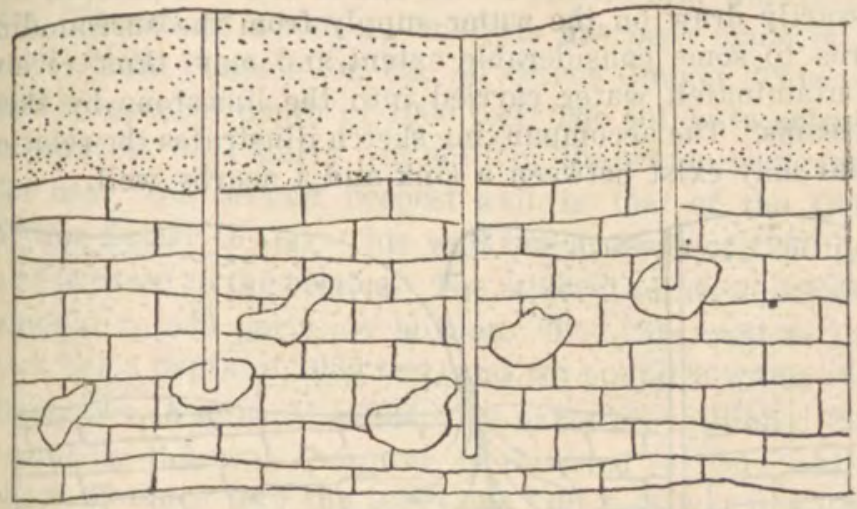

Fig. 5.-Sketch illustrating the varying depth of wells entering the limestone. In order to obtain a large supply of water it is necessary to penetrate the limestone until either a solution cavity or a porous stratum is reached. The breaks in the limestone represent irregularly occurring solution cavities, two of which are reached by wells. 


\section{CONTAMINATION.}

The deep waters are in much less danger of contamination from organic sources than are the shallow. The organic material, and with it the disease-producing germs, is filtered out as the water penetrates through the surface sands and the porous rocks. The comparatively deep waters may, however, under certain conditions, become contaminated. Many of the sinks occurring in the limestone area are passageways directly through to the limestone water horizon. It not infrequently happens that small streams flowing through a town find entrance into the limestone through these sinks. These streams often receive trash, rubbish and filth of various kinds. The impurities carried by the streams often reach the underground water supply without having been filtered or sufficiently exposed to the sunshine. The water in such streams should be kept as free from organic impurities as possible. Wells from which a large amount of water is pumped necessarily draw on the water supply from the surrounding area to some considerable extent and may thus receive contaminated water carried into the limestone by these streams. The accompanying sketch illustrates the relation that may exist between a sink and a nearby well.

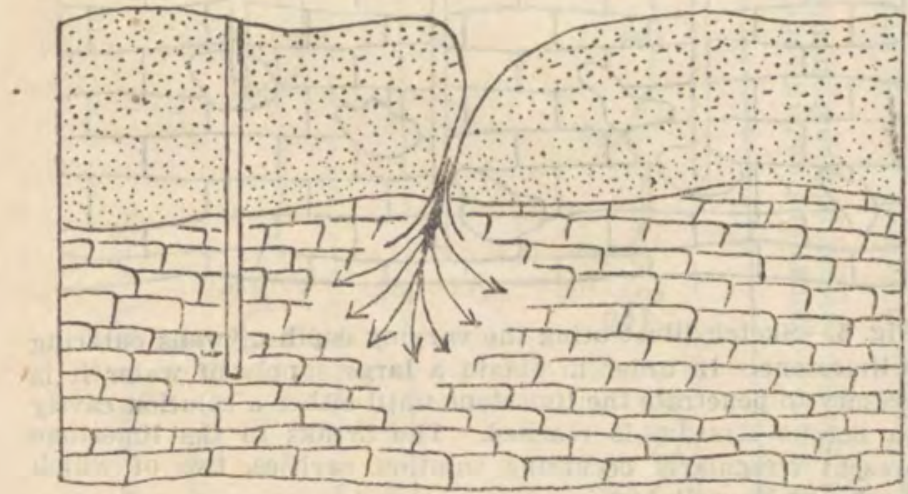

Fig. 6.-Illustrating danger of contamination of a well by impure water entering through a sink. The water flowing into the sink enters a cavity in the limestone and spreads through the open spaces in the rock, some of it probably reaching near-by wells. 
The danger of contamination from the bored wells used to carry off sewage is discussed on pages 64 to 67 .

Contamination as commonly used refers to organic contamination. Water also takes minerals into solution which may be considered as mineral contamination. For drinking purposes the minerals thus dissolved may be beneficial or injurious, according to the minerals dissolved and the amount in solution. For irrigating purposes, they are usually not injurious and may even be beneficial as many of the waters contain from a trace to one or two parts per million of phosphoric acid. For boiler and household purposes the mineral solids in solution are detrimental The amount of minerals in solution in the water increases, as previously stated, in a general way with the depth of the well. The deepest well in central Florida of which an analysis has been made is the well of the Pearson Oil Co., in Citrus County. This well has a reported depth of 1900 feet. The solids in solution amount to 6474 parts per million, the water being unfit for use. The second deepest well is that of the Ocala Water Co. at Ocala. This well has a depth of $1 \dot{2} 50$ feet, and is cased to the bottom. The mineral solids in solution amount to 659 parts per million. The City well at Live Oak has a depth of 1080 feet, and yet supplies water relatively low in mineral solids (219 parts per million). The casing in this well, however, is reported to reach only a short distance into the limestone and this fact doubtless explains the relatively low proportion of solids. Water may, and doubtless does, enter the boring from all depths below the termination of the casing, and notwithstanding the considerable depth of the well the principal water supply in this case probably comes from no great depth. The mineral solids in solution in the wells of medium depth in central Florida usually range between 125 and 275 parts per million. 


\section{Artesian Prospects.}

The conditions which exist in central Florida are not favorable for obtaining flowing wells. The crest of the anticline lies not far from the center of the peninsula. The dip from the crest is most rapid to the east. Under these conditions pressure sufficient to cause a flow along the side of the anticline would result from the presence of an overlying relatively impervious stratum acting as a confining agent, and preventing the escape of the water. In the absence of this confining stratum a flow may still be obtained, provided the resistance to the passage of the water through the inclined stratum is sufficiently great. The dip to the east carries the limestone beneath impervious strata with the result that a flow is obtained along the St. Johns River and along the east coast. To the south likewise later formations rest upon the Vicksburg. To the west, however, the Vicksburg limestone lies at or near the surface to the coast, such deposits as rest upon it being thin and of local extent.

The shading on the map indicates those parts of the State in which flowing wells may be obtained. There are as will be seen, two principal artesian areas: the East Coast area and the Southern Gulf Coast area. Flowins; wells on the east coast have been obtained as far south as Pralm Beach, although the water in the well at this last locality was too salty for use. The Gulf Coast area extends rather farther north than is indicated on the map, flowing wells at or near the sea level having been obtained along the Pinellas Peninsula. Flowing wells oceur locally in some sections not indicated on the map, as at Kissimmee and along the Gulf coast of west Florida. The location of a number of these wells is indicated on the map by a cross.

Of the counties covered by this bulletin, two, namely - Lake and Marion, extend eastward into the St. Johns River area of artesian flow. On the west coast a flowing well, the Pearson Oil Co. well, has been obtained in Citrus 


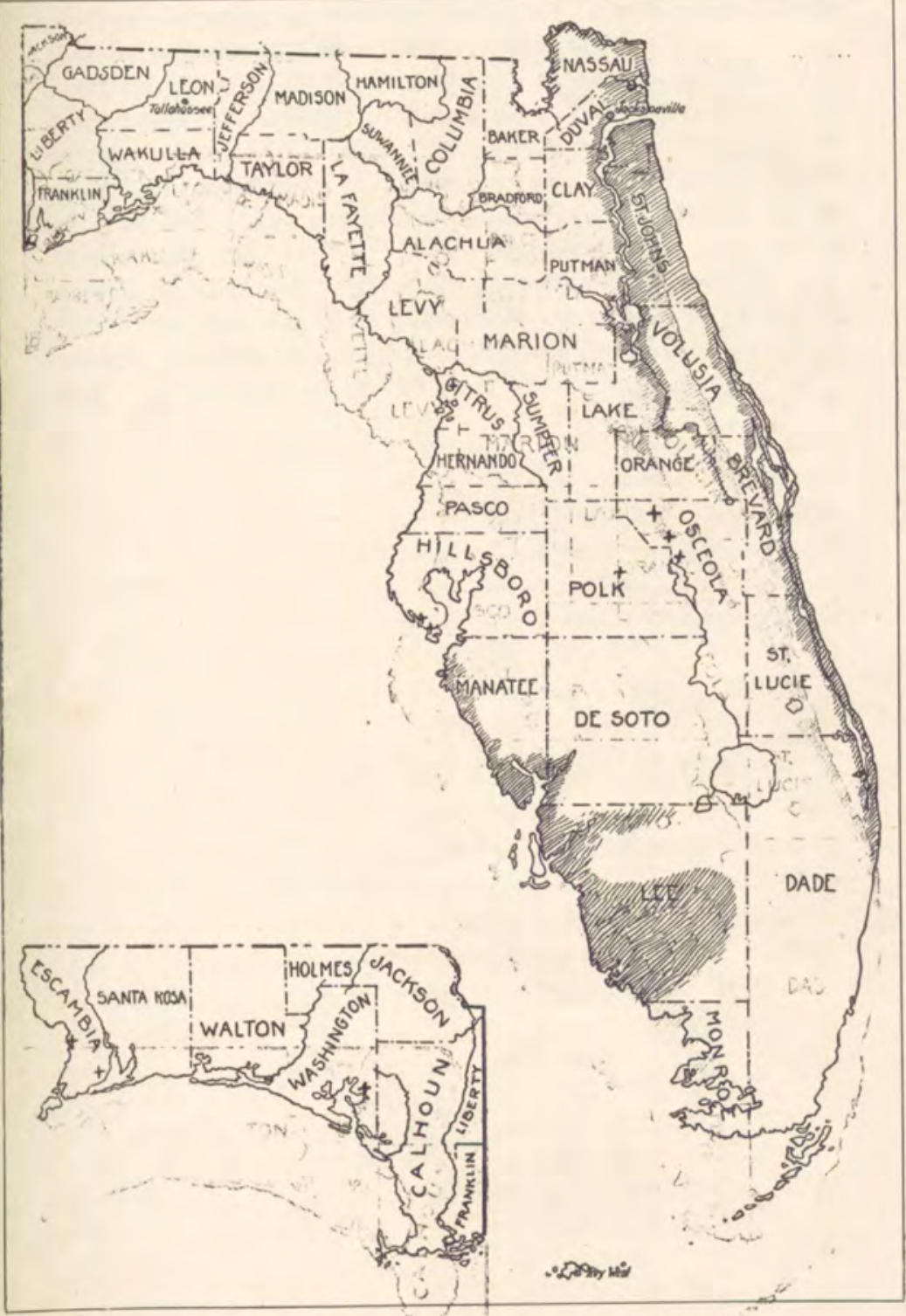

AREAS OF ARTESLAN FLOW IN FLORIDA. 
County. The water, however is too salty for use. A flow has been obtained in a few instances from wells at low surface elevation in the lake region of Lake County. These depend apparently upon local conditions.

Of the deep wells that have been drilled, some have not been properly cased, and hence do not afford a test as to artesian flow. One deep well of the interior, that of the Ocala city water supply, however, is cased the full depth of 1250 feet. The surface elevation at this locality is between 100 and 110 feet above sea-level and the water stands in this well 65 to 70 feet from the surface. A flow from this depth is therefore not to be expected in central Florida, since in this seetion the average surface elevation is from 60 to 150 feet. 


\section{GEOLOGICAL RESULTS OF UNDERGROUND CIRGULATION.}

- The topography of a region is the product of all the agencies that have acted upon the land since its formation. Sedimentary deposits when formed usually lie horizontal or nearly so. Such deposits when elevated, unless violently distorted or folded, form dry land areas, which are either level, with minor irregularities, or have a uniform slope. As soon as exposed, however, eroding agencies begin to develop irregularities in the land surface. Evidence of violent upheavel, distortion or folding, other than very mild flexures, is lacking in Florida. The topographic features of the State are thus mainly the result of the combined action of the eroding agencies which have been working since the first appearance of the peninsula as dry land.

Among these agencies of erosion, underground water has acted in Florida under exceptionally favorable conditions. In areas of considerable slope, and with relatively impervious formations, the surface run-off is large. Under these conditions those features of topography determined by the rapid downward cutting of the surface streams and their tributaries predominate. In Florida the surface lope is slight. The open nature of the soil and rock permits the greater part of the water to enter the earth, establishing subterranean rather than surface drainage. The rocks are prevailingly calcareous and soluble. Under these conditions the work of the underground water predominates over surface erosion. In central Florida the topography, soil, and general surface features are determined to a large extent by the work of underground water.

\section{Solution.}

Solution is the most apparent, and geologically the most important result of underground water circulation. Rain water, while passing through the air, takes into solution a small amount of $\mathrm{CO}_{2}$ gas. To this is added organic and mineral acids taken up while passing through the soil. Increased pressure, as the water descends into the earth, enables the water to hold in solution greater quantities of 


\section{UNDERGROUND WATER SUPPLY.}

gases, acids and salts, all of which greatly increase the dissolving power of the water.

That underground water is efficient as a solvent is evident from the analyses of well and spring waters. Rain water entering the earth with almost no solids in solution, returns to the surface through springs and wells with a load of mineral solids in solution determined by the length of time it has been in the ground, the distance traveled, and the character of the rocks and minerals with which it comes in contact.

Amount of Mineral Solms Removed in Solution.

The mineral matter thus taken into solution is carried along with water, and, while some of it is re-deposited, a large amount is removed annually.

An estimate of the total mineral solids thus removed is difficult. A conception of the largeness of the amount removed is obtained from a consideration of some of the individual springs.

The water of Silver Springs contains, as shown by analysis, 274 parts solids per million parts water. Otherwise expressed, each million pounds of water is carrying with it 274 pounds of solids in solution. Silver Spring is estimated to flow a little more than three million pounds of water per minute $(368,913$ gallons). The interior of Florida is thus being carried into the ocean through Silver Springs at the rate of more than 340 pounds per minute, or about six hundred tons per day.

The total solids removed in solution through six other springs of central Florida, expressed in tabular form, gives the following results :

\begin{tabular}{|c|c|c|c|c|}
\hline$-1+2+2$ & & Tatoloolide & low & \\
\hline Name of $\mathrm{Sp}$ & County. & $\begin{array}{l}\text { parts per } \\
\text { mil.*) }\end{array}$ & $\begin{array}{l}\text { (gals. per } \\
\text { min.) }\end{array}$ & $\begin{array}{c}\text { moved lbs. } \\
\text { per day. }\end{array}$ \\
\hline lue & Marion & 112.1 & 349.166 & $\begin{array}{r}469,698 \\
59040\end{array}$ \\
\hline Blue ................. & Levy & 196.8 & 25,000 & $\begin{array}{r}59,040 \\
457,056\end{array}$ \\
\hline Ichatucknee...... & Columbia & 311.6 & 180,000 & $\begin{array}{l}457,056 \\
210,150\end{array}$ \\
\hline $\begin{array}{l}\text { Newland ......... } \\
\text { Weekiwachee.... }\end{array}$ & Suwannee & 233.5 & $\begin{array}{r}75,003 \\
100000\end{array}$ & $\begin{array}{l}210,150 \\
273.360\end{array}$ \\
\hline $\begin{array}{l}\text { Weekiwachee..... } \\
\text { White Sulphur... }\end{array}$ & Hernando & 227.8 & $\begin{array}{r}100,000 \\
32,400\end{array}$ & $\begin{array}{r}273.560 \\
64.774\end{array}$ \\
\hline $\begin{array}{l}\text { White Sulphur... } \\
\text { Suwannee....... }\end{array}$ & $\begin{array}{l}\text { Hamilton } \\
\text { Suwannee }\end{array}$ & $\begin{array}{l}166.6 \\
332.7\end{array}$ & $\begin{array}{l}32,400 \\
52,000\end{array}$ & 207,605 \\
\hline juwannee ....... & Suwannee & & & \\
\hline
\end{tabular}

* Organic matter is deducted from the total sollds as given for Suwannee Sulphur and White Sulphur Springs. The organic matter occurring in the other springs is of small amounts and was not separately determined. 


\section{GEOLOGICAL RESULTS OF UNDERGROUND CIRCULATION.}

- The topography of a region is the product of all the agencies that have acted upon the land since its formation. Sedimentary deposits when formed usually lie horizontai or nearly so. Such deposits when elevated, unless violently distorted or folded, form dry land areas, which are either level, with minor irregularities, or have a uniform slope. As soon as exposed, however, eroding agencies begin to develop irregularities in the land surface. Evidence of violent upheavel, distortion or folding, other than very mild flexures, is lacking in Florida. The topographic features of the State are thus mainly the result of the combined action of the eroding agencies which have been working since the first appearance of the peninsula as dry land.

Among these agencies of erosion, underground water has acted in Florida under exceptionally favorable conditions. In areas of considerable slope, and with relatively impervious formations, the surface run-off is large. Under these conditions those features of topography determined by the rapid downward cutting of the surface streams and their tributaries predominate. In Florida the surface lope is slight. The open nature of the soịl and rock permits the greater part of the water to enter the earth, establishing subterranean rather than surface drainage. The rocks are prevailingly calcareous and soluble. Under these conditions the work of the underground water predominates over surface erosion. In central Florida the topography, soil, and general surface features are determined to a large extent by the work of underground water.

\section{Solution.}

Solution is the most apparent, and geologically the most important result of underground water circulation. Rain water, while passing through the air, takes into solution a small amount of $\mathrm{CO}_{\overline{2}}$ gas. To this is added organic and mineral acids taken up while passing through the soil. Increased pressure, as the water descends into the earth, enables the water to hold in solution greater quantities of 
gases, acids and salts, all of which greatly increase the dissolving power of the water.

That underground water is efficient as a solvent is evident from the analyses of well and spring waters. Rain water entering the earth with almost no solids in solution, returns to the surface through springs and wells with a load of mineral solids in solution determined by the length of time it has been in the ground, the distance traveled, and the character of the rocks and minerals with which it comes in contact.

\section{Amount of Mineral Solids Removed in Solution.}

The mineral matter thus taken into solution is carried along with water, and, while some of it is re-deposited, a large amount is removed annually.

An estimate of the total mineral solids thus removed is difficult. A conception of the largeness of the amount removed is obtaiued from a consideration of some of the individual springs.

The water of Silver Springs contains, as shown by analysis, 274 parts solids per million parts water. Other. wise expressed, each million pounds of water is carrying with it 274 pounds of solids in solution. Silver Spring is estimated to flow a little more than three million pounds of water per minute $(368,913$ gallons). The interior of Florida is thus being carried into the ocean through Silver Springs at the rate of more than 340 pounds per minute, or about six hundred tons per day.

The total solids removed in solution through six other springs of central Florida, expressed in tabular form, gives the following results:

\begin{tabular}{|c|c|c|c|c|}
\hline Name of Spring. & County. & $\begin{array}{l}\text { Total solids } \\
\text { parts per } \\
\text { mil.*) }\end{array}$ & $\begin{array}{l}\text { Est. flow } \\
\text { (gals. per } \\
\text { min.) }\end{array}$ & $\begin{array}{l}\text { Solids re- } \\
\text { moved lbs, } \\
\text { per day. }\end{array}$ \\
\hline Blue & Marion & 112.1 & 349166 & 469,698 \\
\hline Blue & Levy & 196.8 & 25,000 & 59,040 \\
\hline latucknee..... & Columbia & 311.6 & 180,000 & 457,056 \\
\hline Newland & Suwannee & 233.5 & 75,000 & 210,150 \\
\hline Weekiwachee.... & Hernando & 227.8 & 100,000 & 273.360 \\
\hline White Sulphur... & Hamilton & 166.6 & 32,400 & 64,774 \\
\hline Suwannee ...... & Suwannee & 332.7 & 52,000 & 207,605 \\
\hline
\end{tabular}

* Organic matter is deducted from the total solids as given for Suwannee Sulphur and White Sulphur Springs. The organic matter occurring in the other springs is of small amounts and was not separately determined. 
As the basis of an estimate of the total solids removed annually from the interior, let it be assumed, (1) that the average total solids in spring water amounts to as much as 219 parts per million, this average being obtained from eight of the typical large springs of central Florida; (2) that the annual escape of the underground water approxi mates the annual in-take, amounting, as previously esti. mated (p. 16), to $460,536,689$ gallons per square mile. Upon these estimates the mineral solids removed amount to a little more than four hundred tons annually per spuare mile.

Of the minerals thus removed, calcium carbonate or limestone greatly predominates, exceeding the combined weight of all other minerals. From the analyses it ap pears that magnesium carbonate, magnesium and calcium sulphates are present in variable, although usually limited, quantities. Chlorides are normally present in small amount, although occasionally, as in the case of Perrian Spring, they are exceptionally high. Silica is present in amounts varying from 5 to 25.5 parts per million. Traces of phosphoric acid and of iron and alumina are usually present.

The several undetermined faetors whieh enter into the above estimates of mineral solids removed make jt diffcult to formulate a concrete statement of the rate of low. ering of the general surface level. Nevertheless, such statements are desired and have a comparative zalue. Assuraing for the rock removed, most of which is limestone, an average specific gravity of 2.5 , a layer one foot thick over one square mile should weigh about two and one-sixth million tons. The calculated rate of removal of this rock is abcint four hundreds tons per square mile per year. From these estimates it would appear that the surface level of the central peninsular section of Florida is being lowered by solution at the rate of a foot in flve or six thousand years.

\section{Underground Cavities.}

The estimates given on the previous page, even allowing for a wide margin of error, indicate the very great amount 
of mineral solids that is being removed in solution from the interior of the State annually. The indications are that this process of solution has continued uninterruptedly throughout a period of time counted by thonsands of years. The effects are everywhere apparent. Solution cavities are exceedingly numerous in the underlying limestone; so much so that it is unusual for a boring to go to any considerable depth without striking a cavity. In some cases the rock is truly honeycombed with cavities, and no boring has reached a depth beyond the zone of their occurrence. It is possible that deposits too soft to support the drills are occasionally struck and are sometimes mistaken for cavities, but that many of these wells actually end in cavities is not to be doubted. Shaler maintains that the presence of these cavities at a great depth in the limestone necessarily implies a considerable elevation of the penin. sula at the time of their formation.* The writer agrees with the view that oscillations in the level of the peninsula have occurred, a former greater elevation being indicated by certain old valleys now filled with sand and clay. However, he believes it unnecessary to assume elevation to account for the cavities. It is without doubt true that solution goes on more rapidly in the zone above the under. ground water level. That solution continues below the water level is sufficiently evident, however, from the fact already noted that the total mineral solids in the water increases on an average with the depth from which the water comes. Although the return eirculation is slow, there is no doubt that some of the water from great depth returns through springs and otherwise escapes into the ocean, earrying with it its load of mineral solids, thus forming and enlarging cavities.

\section{SINK Holes.}

The surface of the interior of Florida is dotted with sink holes of all sizes, from a few inches to several rods in diameter. Their circular outline and often great depth, render them noteworthy features of the landscape. They

*Evidences as to the Change of Sealevel. Geol. Soc. Am., Bull. VI., 1895 , p. 155. 
occur irregularly and are not uniformly distributed. Certain sections underlaid by readily soluble limestones are particularly liable to sinks.

An account of the manner of formation of these sinks has been given by the writer in a previous publication.* This account is, in part, as follows: "When first formed, the typical sink throughout this area (interior of Florida), is an opening leading from the surface through the superficial deposits to or into the limestone below. Many of these sinks are perfectly cylindrical, not funnel-shaped. This is especially true of the smaller sinks. As a result of the subsequent caving of the banks, the bottom usually becomes clogged and the sides sloping. The formation of these sinks is practically instantaneous and results from a sudden caving of the earth. In size they vary from a few feet to many rods in diameter. So frequent is their formation in certain sections, notably the phosphate mining area of Alachua and Columbia Counties that one must be on the lookout in driving through the country for newly formed sinks. Indurated layers exposed along the sides of the sinks are rough-edged and bear evidence of fracture due to the sudden giving away and breaking under the weight of the load above. The depth of the sinks is probably quite variable. As a rule, they reach through and connect with the permanent underground water horizon. Some reach much below the water line."

"A sink of this type was examined by the writer within a few hours after its formation about one mile south of Juliette, in Marion county, in 1905. This was a small sink, not more than eight feet in diameter, and of the usual cylindrical form. The sides down to the water level were, so far as could be determined, entirely of clay. The sink, which had formed directly under the railroad track, was caused possibly by the jar of a passing train, the engine of which had passed safely over. The water rose immediately in the sink to the static head of the water in that locality."

"The writer recalls having often seen similar tubular

*Science, Vol. XXVI., p. 417, 1907. 


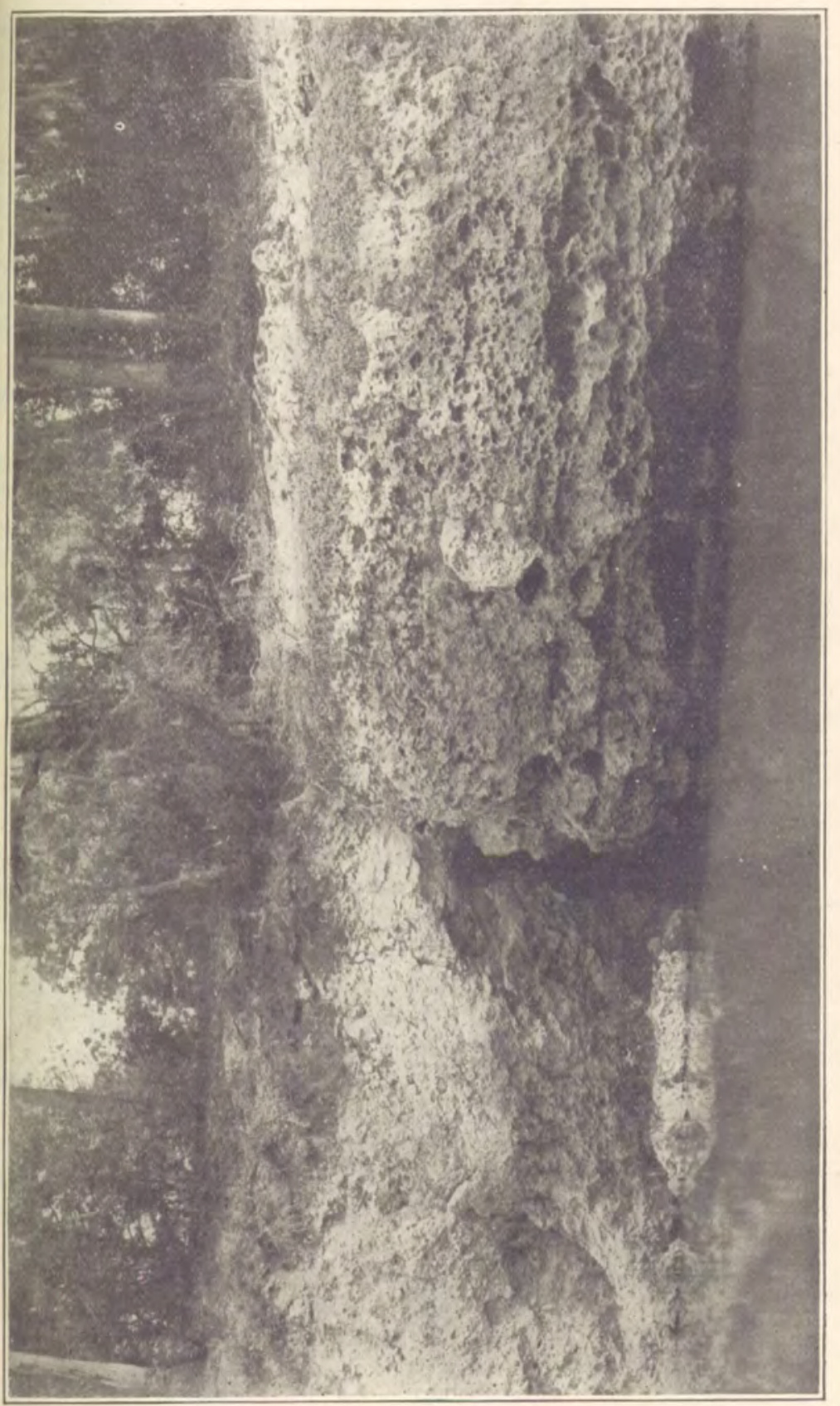

要 
openings reaching from the surface to the runway of abandoned coal mines, the "cave-in" occurring in these cases through a thickness of forty or fifty feet of clays and shales. From analogy it seems probable that the formation of the sinks in question results from a gradual caving of the clay from the bottom, assisted, perhaps, by the removal mechanically of a part of the material by underground water. Finally a point is reached at which the entire remaining mass suddenly gives way. While some of these sinks are in clay formations entirely, others break through a considerable thickness of limestone."

Sink holes are characteristic of that part of the State in which soluble limestone lies at or near the surface. If the limestone is covered by too great a thickness of clays or other impervious formations, sink holes do not form. Nor do sinks occur in areas of artesian flow, since the impervious strata which retain the artesian water likewise prevent the downward percolation of surface water necessary to the formation of a sink.

Sinks after being formed tend to fill up by the caving of the sides, and as a result of the debris washed and blown into them. All ages of sinks, from the new to the old and almost obliterated, are to be observed. The new sink is recognized at once by its almost perpendicular sides, and by the fresh untarnished appearance of such rocks and clays as are exposed along the side. The somewhat older sink is recognized by the beginning of a growth of hard wood vegetation along its sides. The appearance of the sink at later stages in its history will depend upon local conditions and especially whether it is in a clay or in a limestone region. Sinks located in a clay region, of which those on the grounds of the State University at Gainesville are good examples, will usually become clogged at the bottom by the clay and mud washed into them. The banks then slump and wash down, the slope becoming less steep. Surface water collects, forming a pond and in the course of time the sink is filled, leav. ing hardly more than a depression. Sinks located in a limestone country, or with surrounding rock strong 
enough to prevent rapid wash and falling of the sides resist filling up longer. Under these conditions the sink remains open at the bottom, that is, retains its connection with the deep water horizon indefinitely, the water that runs into it from the sides passing out through the bottom. An illustration of such a sink is the Devil's Mill Hopper, near Gainesville. This large sink is rather old, as indicated by the vegetation along the sides and in the bottom. Some mud and clay has washed in, but the outlet through the bottom is still sufficiently open to permit the water to escape. In its last stages a sink appears merety as a depression and is finally obliterated. The location of an old sink or solution hole is occasionaly discovered in the course of well drilling.

A description of the formation of a sink contained in Bartram's Travels (179) may serve to illustrate the im. pression made by this unusual occurrence upon early English travelers and upon the Indians. The account is given as related to Bartram by a trader, who was an eye witness to the occurrence, and is confirmed, Bartram states, by one or two other traders and by the Indians. The account is as follows:"

"This trader being near the place (before it had any visible existence in its present appearance) about three years ago (as he was looking for some horses which he expected to find in these parts) when, on a sudden, he was astonished by an inexpressible rushing noise, like a mighty hurricane or thunder storm, and looking around, he saw the earth overflowed by torrents of water, which came, wave after wave. rushing down a vale or plain very near him, which it filled with water, and soon began to overwhelm the higher grounds. attended with a terrific noise and tremor of the earth; recovering from his first surprise, he immediately resolved to proceed for the place from whence the noise seemed to come, and soon came in sight of the incomparable fountain, and saw, with amazement, the floods rushing upwards many feet high, and the expanding waters, which prevailed every way, spreading themselves far and near: he at length concluded (he said) that the fountains of the deep were again broken up, and that a universal deluge had commenced, and instantly

*Travels through North and South Carolina, Georgia, East and West Florida, by William Bartram, Philadelphia, 1791, p. 239. 


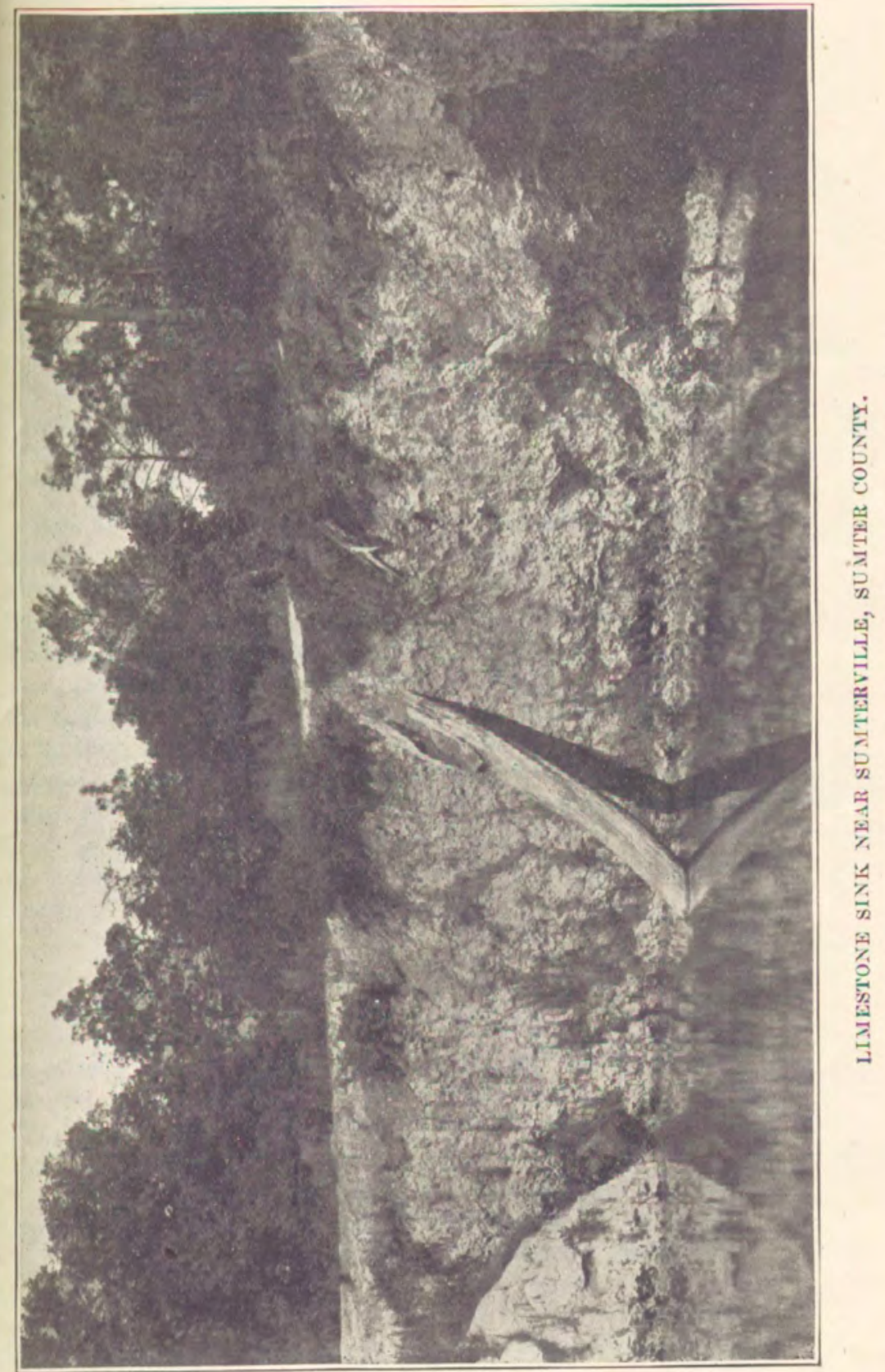


turned about and fled to alarm the town, about nine miles distance, but before he could reach it he met several of the inhabitants, who, already alarmed by the unusual noise, were hurrying on towards the place, upon which he returned with the Indians, taking their stand on an eminerice to wateh its progress and the event: it continued to jet and flow in this manner for several days, forming a large, rapid creek or river, descending and following the various courses and wittlings of the valley, for the distance of seven or eight miles. emptying itself into a vast savanna, where was a lake and sink which received and gave vent to its waters."

"The fountain, however, gradually ceased to overflow, and finally withdrew itself beneath the common surface of the earth, leaving this cepacious bason of waters, which, though continually near full, hath never since overflowed."

This sink, known at that time as "Alligator Hole," is lonted, as shown by the text, in the northwestern part of Levy County in the vicinity of Manatee Springs, and not far from the ancient Indian village and trading station of Talahasochte. The account by Bartram is doubtless some what embellished. The least reliable feature, perhaps, is the amount of water reported to flow from the opening. It is true, however, that the static head of the underground water of this part of the county is sufficient to bring the water within a few feet of the general surface level. Under these conditions a temporary flow doubtless occurred, due to the rebound of the water following the caving of the earth.

\section{Disappearing Streanas.}

The abrupt disappearance of small or medium-sized streams into the depth of the earth is a not uncommon feature of inland Florida, giving rise occasionally to no little wonderment. The streams enter the earth through sinks of the character of those described above.

After the formation of a sink it invariably happens that some part of the rainfall from the immediately surround ing area, as a result of natural depressions, flows over the edge and into the sink. In doing so the water will necessarily begin the cutting of a ditch across the edge. The deeper the ditch is eut the more readily is the water 
enabled to enter the sink. The farther the ditch is extended headwards from the edge of the sink the more water it receives. This small start is the beginning of the development of a disappearing stream. The subsequent history of the stream is determined by the character of the rock through which it has to cut, and the length of time it is allowed to operate. Given sufficient time, the rivulet cuts headwards, increasing its drainage area, gathering more water, and attaining to the respectable size of a stream. The kind of a valley cut by the stream, whether with steep or sloping sides, with waterfalls or without; with uniform or with interrupted grade; is determined by the kind of deposits through which or over which it flows The stream in these respects develops as do other streams cutting back from their origin. Thus, if the deposits through which it is cutting are of uniform hardness the bed of the stream will have a uniform slope. If, on the other hand, the deposits are made up of alternately hard and soft layers, the stream crossing the edge of the hard layers and falling onto the more easily eroded softer layers forms waterfalls.

High Falls, about nine miles south of Lake City, in Columbia County, illustrates a stream which, originating from a sink, has cut back a half mile or so through var ous kinds of deposits, and has developed a deep canyon in which are found rapids, many small pot holes, and other features more or less out of the ordinary for Florida streams.

A second type of disappearing stream, or rather of a stream having a different history, in that it becomes a disappearing stream by accident, is illustrated by Falling Creek, in Columbia County. This stream flowed originally into the Suwannee River. In the course of time, however, a sink formed in or near its bed. The sink was of large size and of considerable depth, and resulted in deflecting the course of the stream. The time since the formation of the sink and the deflection of the stream is measured by the depth and the length of the canyon that has been cut. The alternating strata of hard and soft rock at this locality have resulted in the formation of a waterfall, and 
a measurement of the average recession of this waterfall obtained by observations running through a series of years, would, perhaps, afford a basis for an approximato estimate of the time which has elapsed since the formation of the sink. At first this waterfall was located at the edge of the sink. Little by little the waterfall has receded upstream until it has reached its present position, nearly a mile above the sink. The fact that Falling Creek has a deeper and a longer canyon than has High Falls does not necessarily indicate a greater age for Falling Creek sink. The stream which enters Falling Creek was an established stream carrying a regular supply of water at the time the sink was formed, hence began the cutting of the falls with full force at once. High Falls, on the contrary, had to commence its history under very different conditions. At the time of the formation of the sink there was no ready established stream. On the contrary, the stream itself had to be developed, and still carries much less water than does Falling Creek. High Falls sink may, therefore, be actually older, notwithstanding the shorter eanyon eut, than is Falling Creek sink.

The subsequent course of streams entering sinks is a matter of conjecture, one of two conditions may prevail. It is impossible that after entering the limestone the stream is confined to a restricted channel, and hence forms in a real sense an underground stream. This condition probably prevails in the vicinity of large springs or other point of ontlet for underground water. Most of the streams, however, after passing below the ground water level, probably lose their identity as streams and mingle with the general supply of underground water.

\section{Solution Basins.}

Associated with sinks and disappearing streams are solution basins. The basins, like the sinks, are due to the more rapid solution of the rocks underlying one locality than those of another. The process is similar in either case, the lowering of the basin being in fact attended by the formation of sinks. The occurrence of many sinks 
indicate a locality that is being carried down by solution more rapidly than the surrounding area. This rapid solu tion continues until the basin is reduced almost or quite to the underground water level.

Upon approaching the underground water level the rate of solution is checked, owing to the fact that solution goes on more rapidly above than below the water level. From this time enlargement of the basin continues through formation of sinks at the sides, the formation of each sink enlarging the total area of the basin.

Basins of this type are very common in the State. When dry they are known as "prairies"; when filled with water they become lakes. Numerous illustrations may be found in the interior of the State, "Payne's Prairie," at Gainesville, together with surrounding small basins, may be mentioned as a typical example. This basin in the southeastern part of Alachua County, represents a section in which underground solution has greatly reduced the original surface level. At an earlier stage the drainage from this part of the county passed off' through Orange Lake and the Oklawaha River to the St. Johns River, the tributaries of the drainage system taking their origin in what is now the plateau region of northeast Alachua County. The soluble Vicksburg Limestone underlying this section was removed by solution more rapidly than the less soluble rocks to the east, with the result that the basin has now been lowered to a level of from 60 to 65 feet This is equal to or below that of the former outlet through Orange Lake. The drainage from this section now passes off through Alachua Sink. If for any reason the flow of water into the sink is checked, the "Prairie" becomes a lake. Under extremely heavy rainfall the lake would probably rise to a level permitting eseape through its former outlet.

\section{Deposition and Replacement.}

The work of underground water is not confined to solution. The mingling of water in the earth may be regarded as a chemical experiment in which many ingredients are brought together. Under these conditions chemical reactions take place. In calcareous rocks solution predomi- 
nates; but deposition and replacement also occur. Shells and corals in the limestone, originally calcareous, have in many instances become silicified. This is invariably true of the shells imbedded in the fiint masses, indicating that the flint itself has been deposited by underground water since the formation of the limestone. Locally, the limestone has become very compact and the fossils destroyed, a result also brought about by the underground water. In the case of the flint masses the process has been, apparextly, replacement of the calcium carbonate $\left(\mathrm{Ca} \mathrm{CO}_{3}\right)$ by silica $\left(\mathrm{SiO}_{2}\right)$ held in solution in the water. Under these conditions the form and structure of the shells are retained, although the substance of the shell is changed from calcium carbonate to silica. A similar process apparently accounts for the formation of certain rock phosphates, calcium phosphate in this case replacing calcium carbonate.

These changes due to the underground water ultimately affect the topography. The flint masses resist erosion and stand out as ridges, while the limestone erodes in some localities more rapidly than in others. The resulting topography is characterized by the rounded hills and the solution valleys, seen in much of central Florida. 
DRAINAGE OF LAKES, PONDS AND SWAMP LANDS BY DEEP WELLS.

The low elevation of the Florida peninsula, the resulting general flatness of the country, together with the slightly rolling topography, leads in many localities to the formation of lakes, ponds, swamp and marsh lands. The drainage of the ponds and marshes, and indeed even of the lakes, becomes, under certain conditions, a matter of the first importance to the healthfulness and development of the locality. Not infrequently lands valuable for cultivation are rendered unavailable by overflow during the rainy season. Ponds are often unsightly and a menace to health, while the lakes, ordinarily desirable, may, under certain conditions, require partial drainage to avoid overflow of the surrounding lands. Many of the ponds and lakes lie in depressions below the general surface level, rendering surface drainage impossible or impracticable.

\section{Natural Drainage Wells.}

Ponds and lakes of this character are not infrequently drained by sinks occurring in them. The existence of a surface pond or lake is dependent upon the occurrence of a relatively impervious sub-stratum which prevents the downward percolation of the water. The sinks afford an opening through the impervious stratum. The manner of the formation of sinks has been already described. As a result of slow solution a cavity of considerable size is formed in the underlying rock, the cavity gradually enlarging until the overlying deposits break and cave suddenly. When such a sink forms, the water rushes through rapidly, enters the pervious rock below and is conducted away to join the underground supply. Illustrations of drainage through sinks in this way may be taken from almost any county of the interior of Florida. Payne's Prairie, or Alachua Lake, near Gainesville, and Lake Jackson, near Tallahassee, will serve as illustrations of large lakes drained in this way. Lake Jackson was thus àrained in 1907. This lake is of irregular shape and has 
an area of several thousand acres. In April, 1907, a sink formed near the southwestern side of the basin, rapidly draining the lake. In June a second sink, formed to the south of the old sink, carried off the water in a local depression surrounding it. Mud and surface material were carried into the sink, with the result that the underground outlet was soon clogged, preventing further escape. Seepage from the sides, together with the rainfall of the following summer, converted the basin into a lake again.

Payne's Prairie at Gainesville, has an area of 18 or 20 square miles. This section was visited by William, Bartram in the summer of 1700 . It was then known as the "Alachua Savanna," and afforded pasturage to large herds of horses and cattle belonging to the Alachua tribe of Indians. With regard to the sinks, Bartram says:11

"We alighted in a pleasant vista, turning our horses to graze while we amused ourselves with exploring the borders of the Great Sink. In this place a group of rocky hills almost surround a large basin, which is the general receptacle of the water, draining from every part of the vast savanna, by lat. eral conduits, winding about, and one after another joining the main creek or general conductor, which at length delivers them into this sink; where they descend by slow degrees, through rocky caverns, into the bowels of the earth, whence they are carried by secret subterraneous channels into other receptacles and basins."

"There are three great doors or vent holes through the rocks in the sink, two near the center and the other one near the rim, much higher up than the other two, which was conspicuous through the clear water."

Although the two large sinks were in existence then as now, the above description appears to refer more particularly to the North Sink, the first approached by Bartram. When visited by James Pearce in 1824 this basin was still a dry land area. Pearce says of it: ${ }^{2}$

"In a section of the hilly district of Elast Florida called Alachua, I visited a sink filled with water, covering an acre. It is the outlet for a mill-stream that winds through a handsome prairie, and plunging into the rocky basin takes a subterranean course."

${ }^{1 B}$ Bartram's Travels, L. C., p. 203.

2 Am. Jour. Sci., Vol. IX, 1825, p. 125. 
For nearly fifty years after Pearce's visit the prairie was used for cattle grazing and to some extent for farming. About $1871,{ }^{1}$ however, the sink became clogged. When seen by Professor Eugene Smith in 1880, the basin was filled with water, forming a lake. Smith says of it:2

"A small creek flowed through this basin, disappearing near its northern edge into an underground channel. During the great storm of 1871 this outlet was closed, and the "prairie" has become a lake several miles wide and from fifteen to twenty feet deep."

The body of water thus formed was known for many years as Alachua Lake, and is reported to have been navigable for small steamers. The lake continued until the summer of 1891, when it was gradually lowered and drained through a sink. Since this time it has, with the exception of temporary overflows, continued as dry land. Levels were made under the direction of the State Survey in October, 1907. The water level in the sink at that time was found to be 52.67 feet above sea. The acturl level of the underground water above sea was then, as shown by the water in the Gainesville city well, 50.66 feet above sea. The water of the prairie was thus lowered it that time practically to the underground water level. The illustration given in plate VI (facing this page), is made from a photograph taken at North Sink at low water stage in 1891 . The water of the sink at the time the photograph was taken in 1891, was several feet lower than when examined in 1907.

\section{BORED WELLS.}

A bored well in the bottom of a pond or lake serves as an artificial opening through the impervious strata and is effective for drainage purposes only when it reaches a porous or cavernous stratum. Such artifieial openings conduct water in the same manner as a sink. It is not to be assumed that every lake or basin within the State can be drained by bored wells, or that this method of drainage is practicable for all swamp lands. It is scarcely nec-

1The date of the clogging of the sink is sometimes given as 1873. (Bull. U. S. Geol. Surv. 84. p. 94.)

${ }^{2}$ Am. Jour. Sci., Vol. XXI, 1881, p. 298. 


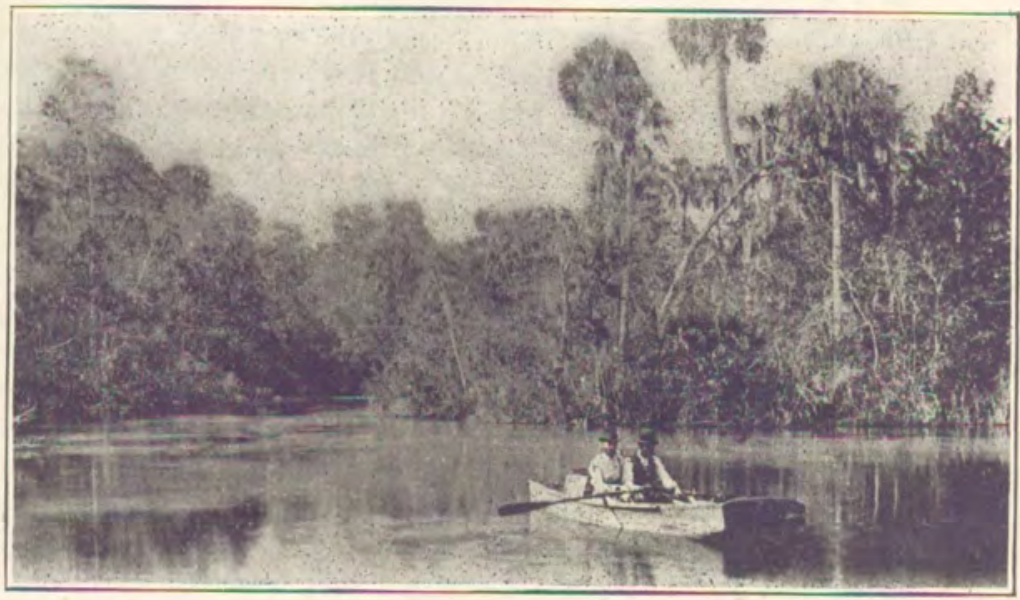

WEEKIWACHEE SPRING, IN HERNANDO COUNTY.

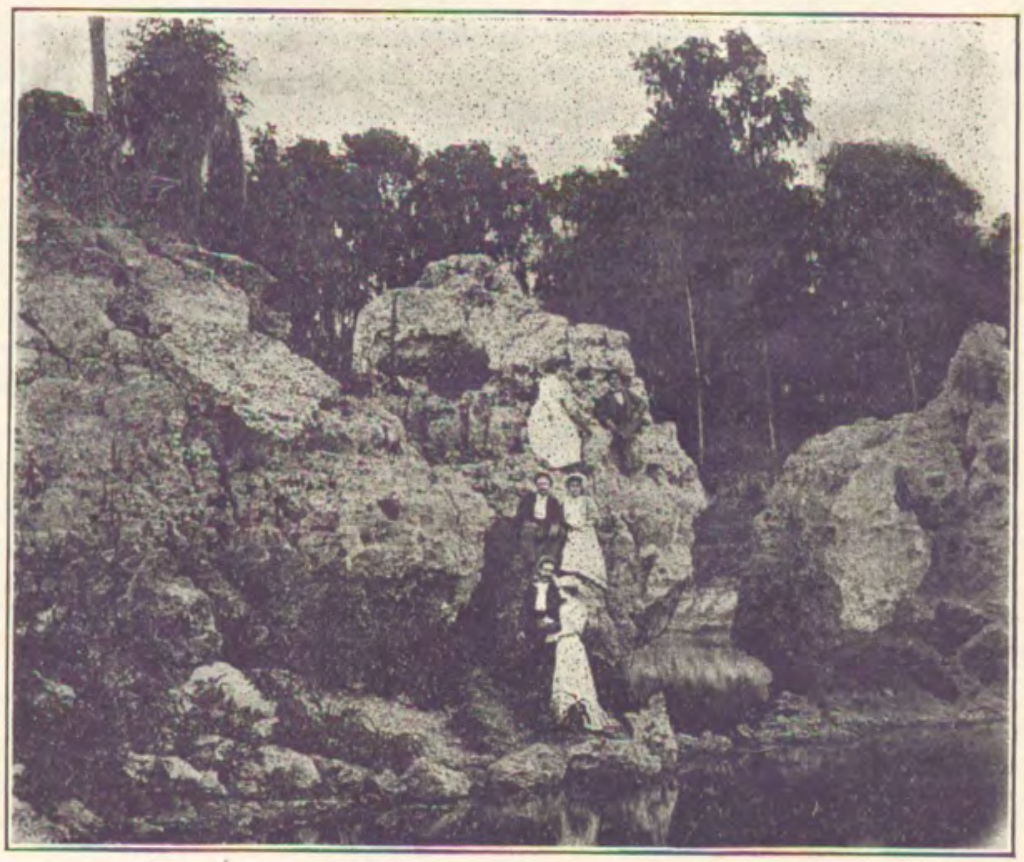

ALACHUA SINK, LOW WATER STAGE, 1891. 
essary to state that this method of drainage can not be applied in areas of artesian flow or other sections in which the static head of the water is such as to bring it to or above the surface level. Many of the basins of the interior have been earried down nearly to or quite to the urderground water level. Under these conditions, it is obvious that they can not be drained by wells.

The possibility of drainage by wells is dependent, first of all, upon the geological structure of the underlying formation. If the water-conducting power of the formation reached by the well is slight, a limit is thereby placed upon the effectiveness of the well. Unless the flow at the bottom of the well is free and ready, the in-take of water is necessarily limited. Many of the wells entering the limestone reach cavities or porous strata sufficiently open to permit of very free movement of water in the rock, either from or into the well. As a general statement, it may be said that if the water level in a well is unaffected by pumping it may be expected to carry water away rapidly; and conversely, if a well carries away water readily it may be expected to supply large quantities to the pump. The principle involved is the same, namely, the free movement of water in the underground formations.

Assuming free movement of the water at the bottom of the well, the rapidity of in-take and hence the efficiency of the well is influenced by (a) size of well; (b) construction of well; (c) depth of water above the mouth of the pipe; (d) distance from the top of the pipe to the underground water level.

(a) The eapacity of a drain pipe increases rapidly with increased diameter. The area of the section of the pipe is proportionate to the square of the diameter. Thus the area of the cross section of a 12 -inch well is nine times that of a 4-inch well. Moreover, for a given velocity the friction of movement is less in a large than in a small pipe.

(b) The construction of a well also affects its rapidity of in-take. When the pipe is cut off squarely at the top according to the usual custom, the full eapaeity of the well is not realized. The rapidity of in-take may be ap- 
preciably increased by the use of a flared or bell-shaped mouth at the top of the pipe.

(c) If the underground water level lies some distance from the surface, and if there is free discharge at the bot. tom of the well, siphonage or draft-tube action increases the rate of flow. When the distance from the top of the pipe to the underground water level is 33 feet or over, the maximum possible draft-tube head of 32.8 feet may be available.

(d) The influence of the depth of water above the mouth of the pipe is as follows: Assuming that there is free discharge at the bottom of the well, the in-take at the mouth of the pipe will be proportionate to the square root of the depth of the water above the mouth of the pipe.

\section{Drainage by Wells at Orlando, Florida.}

The drainage of surface water through bored wells has been used to great advantage by the citizens of Orlando, Florida. A very considerable land area south and east of Orlando, embracing possibly fourteen square miles, lies in an irregular basin with many lakes, marshes, and ponds. The overflow from this area originally drained to and disappeared through a natural sink about one mile east of the city. This sink became clogged in April, $190 \dot{4}$. Unsuccessful efforts were made to re-open this sink, first by removing hyacinths accumulated around the opening, and later by the use of dynamite. In the meantime, heavy and continued rains formed a lake around the sink, overflowing the surrounding lands. In August, 1904, efforts were made to dispose of the water through drainage wells. The first well put down was a two-inch test well. The well reached a porous stratum and was thought to justify the expense of a larger and deeper well. Difficulty and delay were experienced in the drilling, but by August. 1905, two wells, one eight-inch and one twelve-inch, put down at the side and near the original sink, had been completed. Two other wells were started and abandoned owing to the dificulties in drilling. The two successful wells were running at full capacity. It was thought probable that the two wells already put down would prove sufficient. Heavy 
rains followed, and by January, 1906, a considerable area, including some cultivated ground, was flooded, practically all county roads leading into Orlando were partly under water and impassable. The colored settlement known as Jonestown in the suburbs of Orlando was partly under water and uninhabitable; the water was approaching the city of Orlando itself and the situation was becoming alarming. Levels taken by the county authorities indicated that drainage through surface canals was impossible or impracticable. Two additional twelve-inch wells were bored in November and December of 1906 . The effect of these was evident at once, the lake beginning to fall. By February a third twelve-inch well had been completed, making in all one eight-inch well and four twelve-inch wells running at this time. By the end of March the water had returned practically to its normal level and has since been kept under control.

Four of these drainage wells are located near the orig. inal sink and have a uniform depth of 140 feet, a cavity several feet in diameter having been reached at that depth. The fifth well is located one-half mile west of the sink, and terminates in a porous stratum at a depth of 340 feet.

The statement previously made regarding necessity of avoiding contamination of streams entering sinks (p. 42) applies with equal force to drainage wells. The drainage from surrounding residences should not be permitted to find its way to lakes and ponds thus drained. 


\section{DISPOSAL OF SEWAGE THROUGH BORED WELLS.}

The question of disposal of sewage is at present seriously confronting some of the rapidly growing inland towns of Florida. A difficulty in the application of methods ordinarily in use arises from the prevailing general flatness of the country, together with the almost, or locally complete, absence of surface streams. This diffieulty is felt scarcely at all by the residents of the country districts and of the small villages. The soil is prevailingly sandy and porous. Sewage in restricted quantities is therefore very readily received and purified. With the increased growth of the village, however, there results a time when the amount of sewage is so considerable that a sewerage system becomes a necessity.

The disposal of sewage through bored wells has been practiced to a limited extent at a few localities of inland Florida for many years. The wells in use receive usually the drainage from private dwellings, or the combined drainage from two or three dwellings. Oceasionally public buildings, as the court house, city hall, hospital, and hotels, are connected up with these wells. With the rapid growth of the inland towns during the past few years, the number of these private weHs in the towns in which this method is used, have been very greatly increased.

The principles and conditions which permit of disposal of sewage through bored wells are precisely those already explained in connection with drainage wells and natural sink-holes. The sewage is conducted by means of the well either to a cavity or to a porous stratum and is carried away by the underground water circulation.

The depth of the wells intended for sewage is exceedingly variable, in this respect resembling the water wells of the same locality. Practically without exception they reach and enter the artesian water supply. Extreme range in depth is from 35 to 500 feet. In size the wells may vary from two to twelve inches. A cemented cesspool is usually provided, which in the more carefully constructed wells is divided into two divisions. The first division receives the solids; the second is for liquids only, and is separated 
from the first by a screen. The drainage well leads from the second division, the opening being guarded by a sereen.

The question of possible contamination of the water supply through sewage wells is worthy of careful consideration. As previously stated, most of these wells enter the limestone and depend for efficiency upon reaching a cavity or a porous layer in the limestone. Water for drinking, household, and general purposes is in some cases taken from the same limestone formation. Both sewage and water wells are of variable depth. It is the custom in the construction of both water and sewage wells, however, to case the well only to the limestone, or to the first hard stratum in the limestone. Under these conditions a well may receive water from any or all depths below the termination of the casing. The limestone is traversed by solution cavities, and is for the most part, of porous texture, thus permitting circulation of underground water. The belief is often expressed that the cavities entered by these wells represent rapidly moving underground streams, and that these quickly carry away any and all refuse entering them. If this condition prevailed, the case would be but slightly altered, since the rapid removal of contaminated water from one locality would merely endanger a neighboring locality that happened to be on the course of the stream. The information obtained, however, fails, as already stated (p. 34), to give evidence of such rapidly moving streams. On the contrary, the water apparently moves slowly through inter-connecting solution cavities and through the porous rock.

Regarding the inter-connection of solution passages in the limestone, Mr. M. L. Fuller states" that "The intimate connection of the passages, making to all practical purposes a network, has been brought out at several points in this country by the experiments made for the United States Geological Survey by S. W. MeCallie at Quitman, Georgia; by E. H. Sellards at Ocala, Florida, and by G. 1907.

*Bulletin Geological Society of America. Vol. XVIII., page 227, 
C. Matson at Georgetown, Kentucky, at each of which localities salt inserted into sinks or borings found entrance into wells some distance away. In none of the instances, however, was the movement direct from the point of insertion to the well, for the salinity, instead of increasing enormously, as it would have done if such had been the case, showed only relatively moderate fluctuations. The three limestones, although of widely different types, showed the same phenomena in each case, suggesting that it is a normal characteristic of this class of rocks."

In addition to these direct tests, it has been found that in the Florida limestone the water in the sewage wells and that in the water wells of approximately equal depth is under the same static head. This fact, while not of itself proving inter-connection, lends support to that conclusion.

The cesspools in use with most of the sewage wells serve as septic tanks. The efficiency of the septic tank for removing the greater part of the solids from sewage has been abundantly demonstrated. It is also known that the bacteria originally present in the sewage are also reduced in number during the process of fermentation in the cesspool. It has not been shown, however, to what extent the disease-producing bacteria, and particularly Bacillus typhosus, the germ of typhoid fever, is reduced in this process. On this point Professor L. P. Kinnicutt, head of the Department of Chemistry of the Worcester Polytechnic Institute, and Consulting Chemist of the Connecticut Sewage Commission, stated that "very little work has been done with reference to the effect of the septic tank on bacterial life. The second report of the royal commission on sewage disposal of Great Britain quotes experiments made in Manchester, England, showing that the Bacillus coli communis diminishes during the septic period, and the same effect must be felt by the similar and more delicate bacteria such as that of typhoid fever. Similar results are shown at Leeds. The witness's opinion was that the septic tank reduces the number of $B$. coli and the 
more delicate pathogenic germs, and that the total number of bacteria is diminished by 10 or 15 per cent."*

In addition to the reduction of disease germs which may be assumed to take place in the receiving chambers in use in connection with most of the sewage wells, it is apparent that the quantity of water contained in the limestone is large, and that the inter-connection between the wells is indirect. The result is that polluted water introduced through a sewage well is enormously diluted before reaching a water well. One would scarcely maintain, however, that partial reduction of the number of disease germs, together with great dilution of sewage, is a sufficient guarantee against the transmission of disease.

The sewage system which seems to have met with most success in the inland towns is partial removal of solids by means of the septic tank with subsequent further purifcation of the liquids by air and sunlight. This method of sewage purification is being used by Lake City in Columbia County and by Gainesville in Alachua County.

* Digest of the testimony taken in the case of the State of Missouri v. the State of Illinois on Pollution of Illinois and Mississippi Rivers by Chicago Sewage. Water Supp. Paper, U. S. Geol. Sur. No. 194 , p. $285,1907$. 


\section{WATER ANALYSES.}

Water analyses are made for the purpose of determining either the mineral constituents or the sanitary quality of a water, or both. A mineral analysis differs from a sanitary analysis both in the objects sought and in the methods employed. The merits of a water for use in boilers, laundries, and for general commercial and household purposes are determined by a mineral analysis. The determination of the merits as well as the healthfulness of a water for drinking purposes may require both a mineral and a sanitary analysis.

When a quantitative mineral analysis is made, the individual mineral constituents in solution in the water are tested for and determined in the form of base and acid elements. The results of the analysis are frequently expressed by the analyst in the form in which the ingredients are supposed to exist combined in the water. The combinations thus expressed, however, are based upon theoretical considerations. Many chemists are of the opinion that a more exact expression of results is secured by listing separately the ingredients determined, without attempting to express their probable combination. Of the analyses which follow, some, including those made especially for the Survey work, are expressed according to the ingredients determined. Those obtained from various sources are published as given by the analyst, several of which are recorded according to the probable combinations of the ingredients.

The interpretation of a mineral analysis is an essentially different matter from the interpretation of a sanitary analysis. If the mineral analysis indicates a high proportion of calcium and magnesium salts, the water is recognized as a "hard" water, or a water requiring much soap to produce a lather, and hence less satisfactory for laundry and household purposes than a "soft" water. Similarly the water may be found, on account of encrusting, corroding, or other constituents present, unsatisfactory for boiler use, while a high percentage of iron renders the water unfit for certain manufacturing purposes. A 
mineral analysis may also indicate the presence of con. stituents either desirable or undesirable in a water intended for drinking purposes, and may have an indirect bearing upon the sanitary quality of the water. Thus, if conitamination from human habitation is reaching a well, chlorine will be found to be relatively high. A high percentage of chlorine, however, does not necessarily imply organic contamination, since chlorine may have been taken in solution from the rocks through which the water circulates, and hence not indicate contamination.

In making a sanitary analysis the chemist determines the amount of organic matter present, the nitrates, the nitrites, the albuminoid and free ammonia, the chlorine, and usually the total solids. Other mineral constituents may or may not be tested for. An estimate of the number of bacteria present is also frequently made. The conclusions as to the fitness of the water for drinking purposes are arrived at by indirect methods. The ingredients deterinined are not of themselves harmful, but are signinicant as suggesting the possible presence or absence of disease germs. In a sanitary analysis the local conditions surrounding the well or spring from which the water comes are important factors in an interpretation of the results. The presence of organic matter, accompanied often by ammonia, nitrates and nitrites, is ordinarily suspicious, The number of bacteria present is of significance chiefly from the fact that when non-disease producing bacteria are numerous some of the disease producing forms are likely âlso to occur.

The analyses which follow are chiefly mineral analyses and were made for the purpose of determining the average mineral character of the water of the different geological iurmations of central Florida. A few of the analyses listed, however, include a determination of the nitrates, nitrites, free and albuminoid ammonia, while several record the amount of organic and volatile matter present in the water. 
SPRings.

Boulware Spring, Gainesville, Alachua County, Fla Analysis by H. Herzog, Jr., 1898.* Fin

Ingredients (according to probable combination). Parts per

Calcium carbonate....................... 34.81

Magnesium carbonate..................... 21.44

Sulphuric acid......................... none

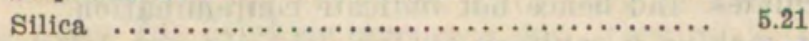

Alkaline chlorides (Chlorine 4.08 ) .......... 8.63

Alumina................................

Nitrates $\ldots \ldots \ldots \ldots \ldots \ldots \ldots \ldots \ldots \ldots \ldots \ldots \ldots$ trace

Nitrites ............................. none

Free ammonia .......................... .043

Albuminoid ammonia $\ldots \ldots \ldots \ldots \ldots \ldots \ldots \ldots \ldots, \quad 06$

Oxygen required to oxidize organic matter..... 1.45

Organic matter $\ldots \ldots \ldots \ldots \ldots \ldots \ldots \ldots \ldots \ldots \ldots, 2.97$

Total solids ...................... 76.80

Magnesia Spring, Hawthorne, Alachua County, Fla. Analysis by W. Dickoie.*

Ingredients (according to probable combination). Parts per

Calcium bicarbonate $\ldots \ldots \ldots \ldots \ldots \ldots \ldots \ldots \ldots \ldots, 110.1$

Magnesium bicarbonate .................. $33.0^{\circ}$

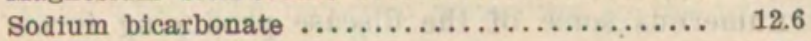

Silica $\ldots \ldots \ldots \ldots \ldots \ldots \ldots \ldots \ldots \ldots \ldots \ldots \ldots \ldots+7.7$

Magnesium chloride $\ldots \ldots \ldots \ldots \ldots \ldots \ldots \ldots \ldots \ldots, 16.2$

Sodium chloride $\ldots \ldots \ldots \ldots \ldots \ldots \ldots \ldots \ldots \ldots, \quad 14.0$

Potassium chloride $\ldots \ldots \ldots \ldots \ldots \ldots \ldots \ldots \ldots . . .6$

Lithium chloride $\ldots \ldots \ldots \ldots \ldots \ldots \ldots \ldots \ldots \ldots$ trace

Ammonium $\ldots \ldots \ldots \ldots \ldots \ldots \ldots \ldots \ldots \ldots \ldots \ldots \ldots$ trace

Phosphates and Sulphates................ trace

195.0

Total solids $\ldots \ldots \ldots \ldots \ldots \ldots \ldots \ldots \ldots \ldots \ldots \ldots, 241.5$

Organic matter and loss on ignition.......... 42.7

Inorganic nonvolatile $\ldots \ldots \ldots \ldots \ldots \ldots \ldots \ldots \ldots, 198.8$

*As given in Water Supply Paper U. S. Geal. Sur. No. 102, 1904. 
Iron Spring, Hawthorne, Fla. Analysis by W. Dickoie.* Ingredients.

Solid matter

Parts per mill.

51.3

Organic matter and loss in ignition........... trace

Inorganic non-volatile $\ldots \ldots \ldots \ldots \ldots \ldots \ldots \ldots, \quad 51.2$

"The iron was originally present as ferrous carbonate, which oxydizes by exposure to air and drops as ferric hydrate. In the solution are left traces of alumina, ferrous oxide, potassium, sodium, some calcium, magnesium as the predominant metal, and some organic matter. The metals are in combination with chlorine and carbonic acid. The reaction of the water is slightly acid (from carbonic acid), but after boiling turns alkaline, indicating the presence of carbonate of an alkall (soda) and that calclum and magnesium are partly present as bicarbonates which precipitate partly on bolling."

Sulphur Springs, Hawthorne, Fla. Analysis by W. Dickoie.*

Ingredients.

Total solid matter $\ldots \ldots \ldots \ldots \ldots \ldots \ldots \ldots \ldots, 273.6$

Organic matter and loss in ignition............ 21.4 ,

Total inorganic $\ldots \ldots \ldots \ldots \ldots \ldots \ldots \ldots, \overline{252.2}$

"The sulphuretted hydrogen in sample had already evap. orated. Reaction acid: turns alkaline after the free carbonic acid is driven out. Contains alkaline carbonates, calcium (predominant), magnesium (little), potassium, sodium, traces of iron and alumina. Some of the calcium is present as carbonate, some as chloride or nitrate. The acids in combination with the metals are carbonic, chlorine, nitric, sulphuric (trace) and silicic."

Ford Spring, Melrose, Fla. Analysis by the State Chemist of Florida (M. 569), 1906.

Total solids 48 parts per million.

Composed of calcium sulphate, magnesium sulphate, and sodium chloride.

*As given in Water Supply Paper U. S. Geol. Surv. No. 102, p, 270, 1904. 
Ichatucknee Springs, Columbia Co. Analysis for State Survey by the State Ohemist, 1908.

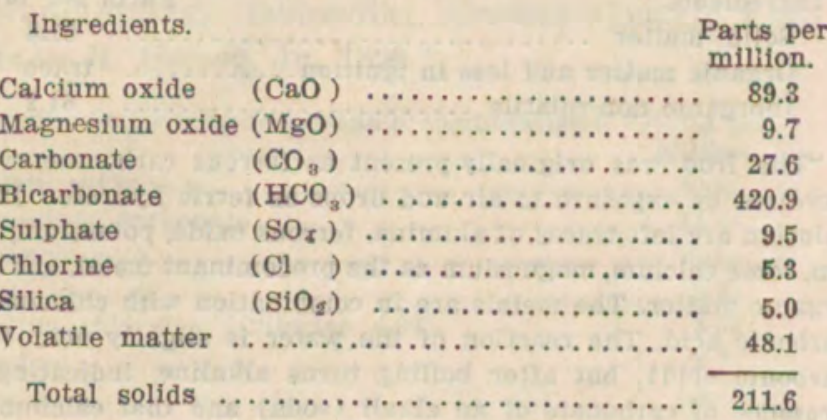

White Sulphur Springs, Hamilton Co. Analysis by N. A. Pratt.

Ingredients.

Lime

Magnesia

Potash

- Soda

Carbonic acid

Sulphuric acíd

Chlorine

Phosphoric acid with oxide of iron.

Silicie acid (soluble)

Organic matter.

Total solids
Parts per million.

44.00

8.51

7.13

18.20

44.18

17.02

12.24

trace

14.40

21.32

Note,-In addition the water contains Free Gases, viz: Hy. drogene sulphide, Carbonic acid, Oxygen, Nitrogen.

The constituents probably combined as follows:

Calcic carbonate or bicarb............... 80.50

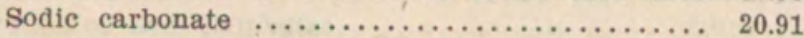

Magnesia sulphate ...................... 25.53

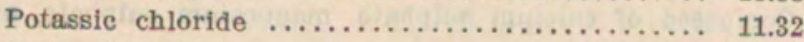

Sodic Chloride $\ldots \ldots \ldots \ldots \ldots \ldots \ldots \ldots \ldots \ldots \ldots, 11.23$

Ferrous oxide (Phosphoric acid trace) ........ 1.40

Silicic acid (soluble) $\ldots \ldots \ldots \ldots \ldots \ldots \ldots \ldots \ldots, 14.40$

Organic matter $\ldots \ldots \ldots \ldots \ldots \ldots \ldots \ldots \ldots \ldots \ldots, 21.32$ 
Weekiwachee Spring, Hernando Co. Analysis by N: P. Pratt. 1904.

Incrusting constituents.

Parts per million.

Carbonate of lime 119.78

Carbonate of magnesia 12.07

Sulphate of lime

Silica

Peroxide of iron and alumina trace

Non-incrusting constituents.

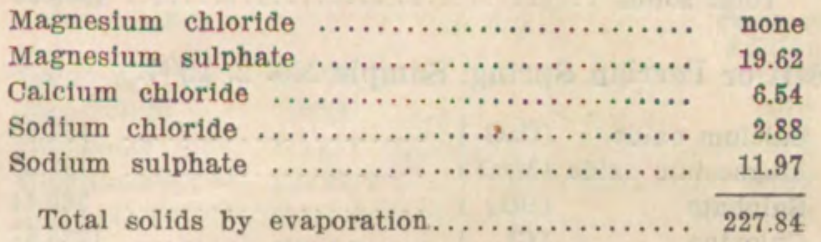

Blue Spring, Levy Co. Analysis for the State Survey by the State Chemist, 1907.

Ingredients.

Parts per million.
Calcium oxide
$(\mathrm{CaO})$ 49.0
Magnesium oxide
( $\mathrm{MgO})$
10.50
Sulphate
$\left(\mathrm{SO}_{4}\right)$
64.40
Chlorine
(Cl )
35.07
Silica
$\left(\mathrm{SiO}_{2}\right)$
5.70
Total solids
196.80

Blue Spring, Marion Co. Analysis for the State Survey by the State Chemist, 1908.

Ingredients.

Parts per million.

Calcium oxide

$(\mathrm{CaO})$ 33.0

Magnesium oxide

( $\mathrm{MgO})$

8.7

Sulphate

$\left(\mathrm{SO}_{4}\right)$

9.0

Chlorine

(Cl )

4.3:

Silica

$\left(\mathrm{SiO}_{2}\right)$

5.8

Carbonate

$\left(\mathrm{CO}_{3}\right)$

Bicarbonate

$\left(\mathrm{HCO}_{3}\right)$

115.9

Total solids 
Salt or Perrian Springs, Marion Co, Analysis for the State Survey by the State Chemist. 1907.

Ingredients.

Parts per million.

Calctum oxide $\quad(\mathrm{CaO}) \quad \ldots \ldots \ldots \ldots \ldots \ldots \ldots, 322.00$

Magnesium oxide $(\mathrm{MgO}) \quad \ldots \ldots \ldots \ldots \ldots \ldots \ldots \ldots, 156.90$

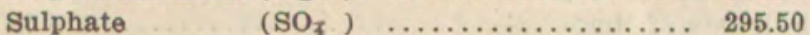

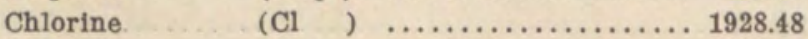

Silica $\quad\left(\mathrm{SiO}_{2}\right) \quad \ldots \ldots \ldots \ldots \ldots \ldots \ldots \ldots, 10.00$

Total solids

4908.00

Salt or Perrian Spring. Sample No. 2. 1907.

\begin{tabular}{|c|c|c|c|}
\hline Calcium oxide & (Ca & & 151.5 \\
\hline Magnesium oxide & $(\mathrm{MgO})$ & $\ldots$. & 193.30 \\
\hline Sulphate & $\left(\mathrm{SO}_{4}\right)$ & $\ldots \ldots \ldots$ & 360.44 \\
\hline Chlorine & $(\mathrm{Cl})$ & $\ldots \ldots \ldots$ & 1238.97 \\
\hline Silica & $\left(\mathrm{SiO}_{2}\right)$ & $\ldots \ldots \ldots \ldots \ldots \ldots \ldots \ldots$ & 30.00 \\
\hline
\end{tabular}

Salt or Perrian Spring. Sample No, 3, Analysis by A. W. Blair. 1901.

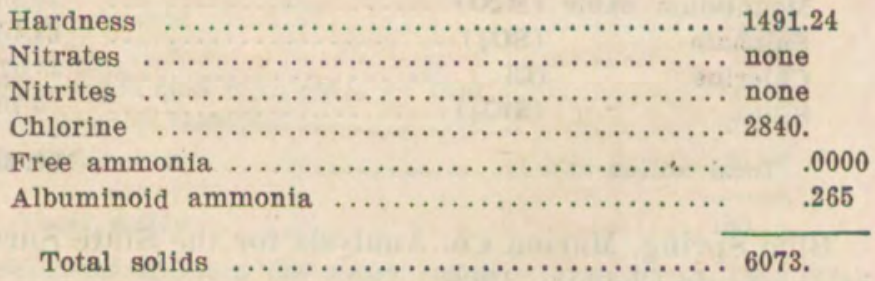

Silver Springs, Marion Co. Analysis made by the U. S. Geological Survey. 1907.

Ingredients.

Parts per million.

Calcium 73.

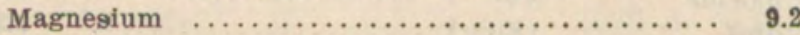

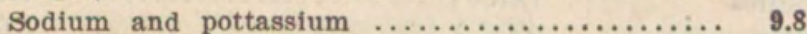

Iron and alumina $\ldots \ldots \ldots \ldots \ldots \ldots \ldots \ldots \ldots$ trace

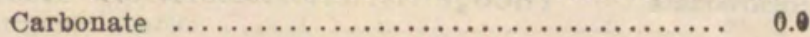

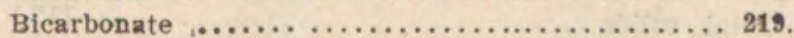


UNDERGROUND WATER SUPPLT.

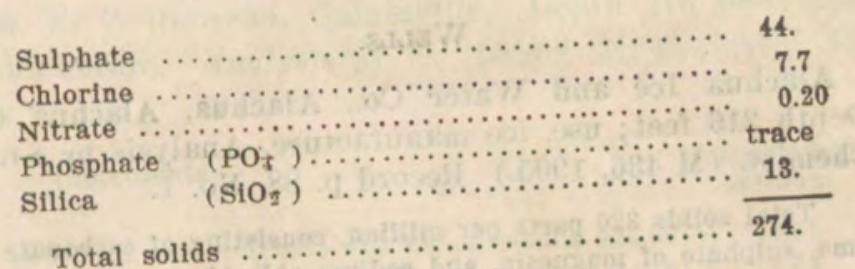

Newland Springs, Suwannee Co. Analysis for the State Survey by the State Chemist. 1908.

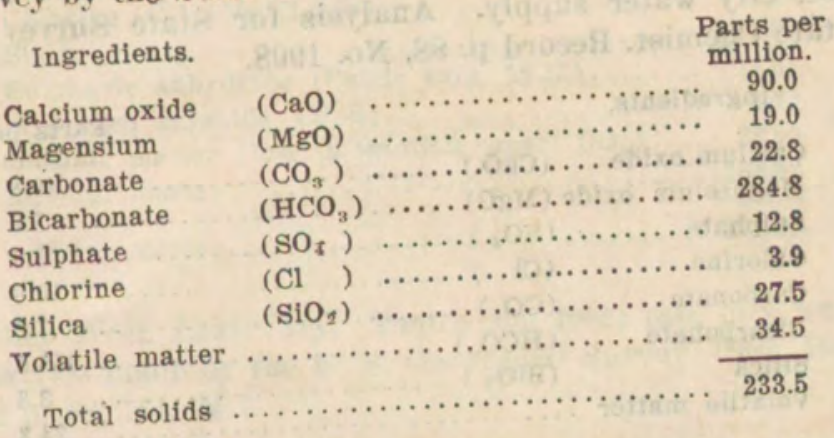

Suwannee Sulphur Springs, Suwannee Co. Analysis made by C. H. Chandler, and C. E. Pellew. 1893.

Ingredients (according to probable combinations) Parts per

(188.91

of 11 me................................. 59.70

Bicarbonate of magnesia...................... 16.47

Bicarbonate of soda............................ 30.46

Sulphate of lime.......................... 10.33

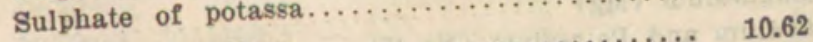

Chloride of sodium........................ 2.59

Oxide of iron and alumina................... 13.79

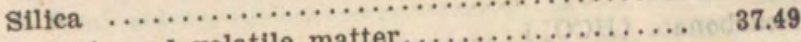

Organic and volatile matter............ $\frac{37.49}{370.33}$

Total solid matter 


\section{WeLLS.}

Alachua Ice and Water Co., Alachua, Alachua Co. Depth 216 feet; use, ice manufacture. Analysis by Stato Chemist. (M 436, 1905.) Record p. 88, No. 1.

Total solids 320 parts per million, consisting of carbonate of lime, sulphate of magnesia, and sodium chloride.

City Well, Gainesville, Alachua Co. Depth 194 feet; use, city water supply. Analysis for State Survey by State Chemist. Record p. 88, No. 1908.

Ingredients.

Calcium oxide

$(\mathrm{CaO})$

Parts per million.

Magnesium oxide $(\mathrm{MgO}) \ldots \ldots \ldots \ldots \ldots \ldots \ldots \ldots, 5.3$

Sulphate

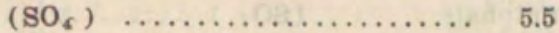

Chlorine

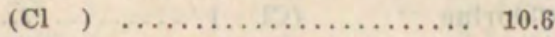

Carbonate

$\left(\mathrm{CO}_{3}\right) \quad \ldots \ldots \ldots \ldots \ldots \ldots \ldots \ldots, \quad 7.2$

Bicarbonate

$\left(\mathrm{HCO}_{3}\right) \ldots \ldots \ldots \ldots \ldots \ldots \ldots \ldots \ldots \ldots \ldots \ldots+255.5$

silica

$\left(\mathrm{SiO}_{2}\right)$

Volatile matter

Total sollds

Diamond Ice Oo., Gainesville, Alachua Co. Depth 316 feet; use, ice manufacture. Analysis by U. S. Geological Survey. Record p. 88, No. 5. 1908.

Ingredients.

\section{Parts per} million.

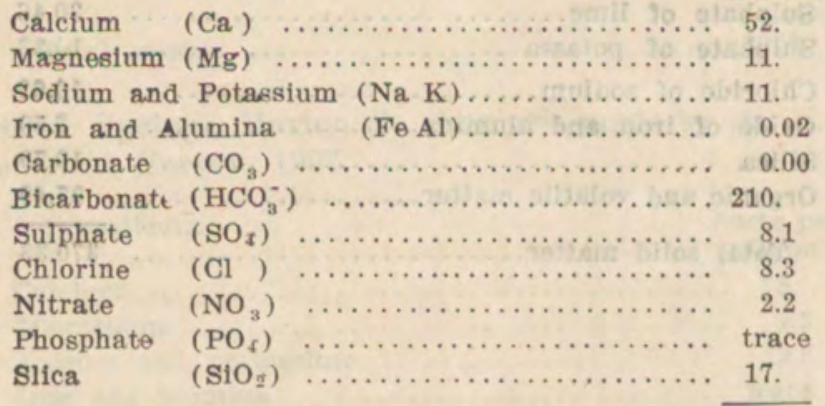

Total solids 
B. F. Williamson, Gainesville. Depth 276 feet; use, manufacture. Analysis by H. Herzog, Jr. Record p. 88, No. 7 .

Ingredients.

Parts per million.

Calcium oxide $(\mathrm{CaO})$ (Caleic carbonate 126.05) .. 78.61 Magnesium oxide (MgO) (Magnesic carb. 74.46) .. 35.62 Iron and alumina oxides (FeAl) ............ 1.70

Sodium oxide (Na) (Alkalies) .............. 3.86

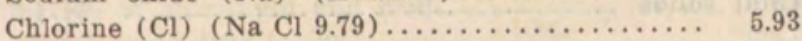

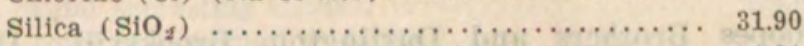

Sulphuric anhydride (Calcic sulp. 19.23) ....... 11.31

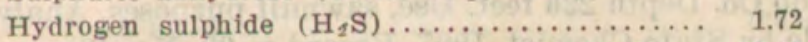

Organic matter (loss in ignition except $\mathrm{CO}_{4}$ )... 28.00

Mineral matter ........................ 168.93

Total solids

306.00

City Well, Lake City. Depth 400 feet; use, city well. Analysis made by the U. S. Geologica' Survey, 1907. Record p. 88 , No. 24.

Ingredients.

Parts per million.

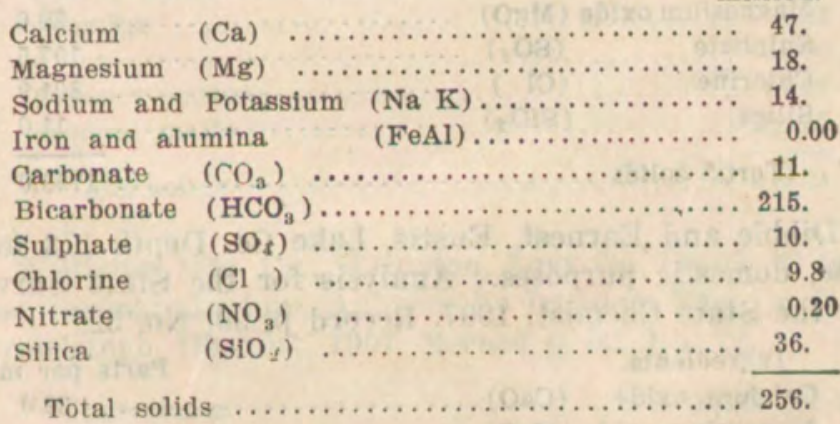

Old City Well, Lake City. Depth 400 feet; use, formerly noed for city supply. Analysis made by the State Chemist (M. 417,1905$)$. Record p. 88 , No. 25.

Total solids 200 parts per million, consisting of carbonate of lime, sulphate of magnesia, chloride of sodium and silica. 
Pearson Oil Well, Crystal River, Citrus Co. / Depth reponted about 1900 feet. Analysis made for State Survey by State Chemist, 1907. Record p. 88, No. 11.

Ingredients.

Parts per mill.

\begin{tabular}{|c|c|c|}
\hline $\begin{array}{l}\text { Calcium oxide } \\
\text { Magnesium oxide }\end{array}$ & $\begin{array}{l}(\mathrm{CaO}) \\
(\mathrm{MgO})\end{array}$ & \\
\hline Sulphate & $\left(\mathrm{SO}_{4}\right)$ & $\ldots \ldots \ldots \ldots \ldots \ldots \ldots$ \\
\hline Chlorine & (Cl) & $\ldots \ldots \ldots \ldots \ldots \ldots \ldots \ldots \ldots$ \\
\hline Silica & $\left(\mathrm{SiO}_{2}\right)$ & n............ \\
\hline
\end{tabular}

Hoopes Brothers and Darlington, Brooksville, Hernando Co. Depth 226 feet. Use, sawmill purposes. Analysis made by State Chemist, 1907. Record p. 90, No. 42 .

Total solids 273 parts per million, consisting of calcic carbonate, sodium chloride, and magnesium sulphate, set down according to the relative preponderance. No organle matter present.

A. A. Thompson, Astor, Lake Co, Depth 82 feet; use, hotel purposes. Analysis for the State Survey by the State Chemist, 1907. Record p. 90, No. 51.

Ingredients.

Parts per mill.

Calcium oxide

$(\mathrm{CaO}) \ldots \ldots \ldots \ldots \ldots \ldots \ldots \ldots \ldots \ldots .233 .0$

Magnesium oxide $(\mathrm{MgO}) \quad \ldots \ldots \ldots \ldots \ldots \ldots \ldots \ldots \ldots, 89.6$

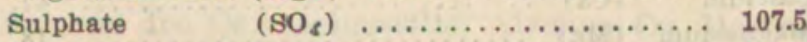

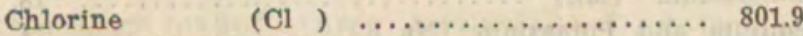

Silica

$\left(\mathrm{SiO}_{2}\right)$

Tortal solids :

1793.0

Dibble and Earnest, Eustis, Lake Go. Depth 173 feet. Use, domestic purposes. Analysis for the State Survey by the State Chemist, 1907. Record p. 90, No. 52 .

Ingredients.

Parts per mill.

Calcium oxide $(\mathrm{CaO}) \ldots \ldots \ldots \ldots \ldots \ldots \ldots \ldots, 32.0$

Magnesium oxide $(\mathrm{MgO}) \quad \ldots \ldots \ldots \ldots \ldots \ldots \ldots \ldots, \quad 6.88$

Sulphate $\quad\left(\mathrm{SO}_{s}\right) \ldots \ldots \ldots \ldots \ldots \ldots \ldots \ldots \ldots, 11.52$

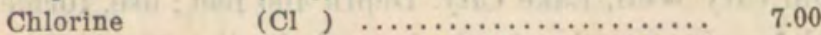

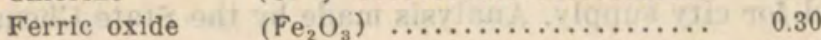

Silica $\quad\left(\mathrm{SiO}_{2}\right) \ldots \ldots \ldots \ldots \ldots \ldots \ldots \ldots, 19.00$

Volatile matter $\ldots \ldots \ldots \ldots \ldots \ldots \ldots \ldots \ldots \ldots \ldots . \quad 9.00$

The Total solids ........................ $\overline{123.00}$ 
Leesburg Ice Co., Leesburg. Depth 98 feet; use, eity supply. Analysis made by Fidelity \& Casualty Co., N. Y. Record p. 90, No. 56.

\section{Ingredients.}

Parts per mill.

Carbonate of lime..................... 85.91

Sulphate of lime....................... trace

Sodium and Potassium sulphates............ trace

Nitrate of lime........................ 5.62

Sodium and Potassium chlorides............. 34.97

Oxide of aluminum and iron................ 3.18

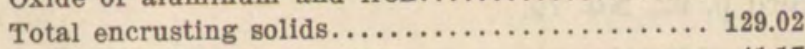

Total non-encrusting solids............... 41.17

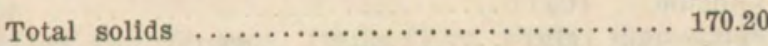

Otter Creek Lumber Co., Otter Creek, Levy Co. Depth 85 feet; use, sawmill purposes. Analysis by H. Herzog, Jr., 1903. Record p. 92, No. 71.

Ingredients.

Parts per mill.

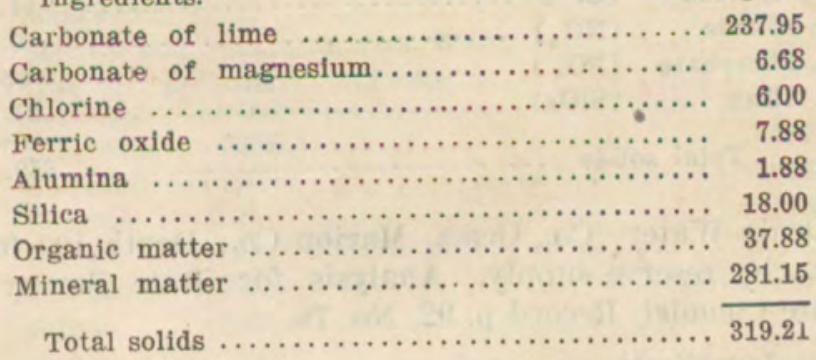

Williston Mfg. Co., Williston, Levy Co. Depth 60 feet; use, ice manufacture. Analysis by Iroquois Mfg. Co. T. L. Crowbaugh, Chemist, 1907. Record p. 92, No. 72.

Ingredients.

Carbonate and sulphate of lime.

Magnesia

Sulphuric acid

Chlorine

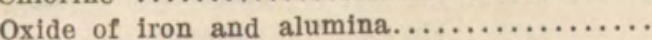

Silica

Total solids
Parts per mill

123.43

51.43

152.58

36.00

some

not determined 
S. H. Gaitskill, MeIntosh, Marion Co. Depth 54 feet; use, general purposes. Analysis by State Chemist, (M 1006, 1908.) Record p. 92, No. 77.

Total solids 145 parts per million, consisting of sodium chloride, calcium carbonate, and sodium sulphate. Organic matter, slight.

Ocala Water Co., Ocala, Marion Co. Depth 1250 feet; use, city supply. Analysis U. S. Geological Survey, 1907. Record p. 92, No. 79 .

Ingredients.

\begin{tabular}{|c|c|c|}
\hline Caleium & (Ca) & \\
\hline Magnesium & (Mg) & 151. \\
\hline Sodium and & d Potassium $(\mathrm{Na} \mathrm{K}) \ldots \ldots \ldots \ldots \ldots$ & 25. \\
\hline Iron & 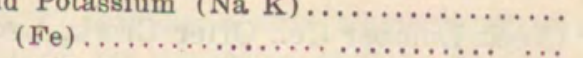 & 18. \\
\hline Carbonate & 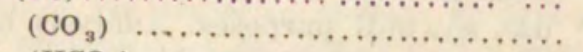 & $\begin{array}{l}0.02 \\
7.7\end{array}$ \\
\hline Bicarbonate & e $\left(\mathrm{HCO}_{3}\right) \quad \ldots \ldots \ldots \ldots \ldots \ldots \ldots$ & 240. \\
\hline ulphate & $\left(\mathrm{SO}_{x}\right) \ldots \ldots \ldots \ldots \ldots \ldots$ & 266. \\
\hline alorine & $(\mathrm{Cl}), \ldots \ldots \ldots \ldots \ldots \ldots \ldots \ldots \ldots \ldots$ & 18. \\
\hline trate & $\left(\mathrm{NO}_{3}\right) \quad \ldots \ldots \ldots \ldots \ldots \ldots \ldots \ldots \ldots \ldots \ldots \ldots \ldots \ldots \ldots$ & 0.22 \\
\hline hosphate & $\left(\mathrm{PO}_{4}\right) \quad \ldots \ldots \ldots \ldots \ldots \ldots \ldots \ldots \ldots \ldots \ldots \ldots \ldots \ldots$ & trace \\
\hline lica & $\cdots$ & 21. \\
\hline
\end{tabular}

Ocala Water Co., Ocala, Marion Co. Depth 190 feet; use, eity reserve supply. Analysis for State Survey by State Chemist. Record p. 92, No. 78 .

Ingredients.

\begin{tabular}{|c|c|c|}
\hline & Fal & ts per \\
\hline Magnesium oxide & $(\mathrm{CaO}) \quad \ldots$ & 171.00 \\
\hline Sulphate & $(\mathrm{MgO}) \quad \ldots \ldots \ldots \ldots \ldots \ldots \ldots \ldots \ldots$ & 37.33 \\
\hline Chlorine & $\left(\mathrm{SO}_{s}\right), \ldots \ldots \ldots \ldots \ldots \ldots \ldots \ldots \ldots \ldots$ & 179.40 \\
\hline Ferric oxide & $(\mathrm{Cl}), \ldots \ldots \ldots \ldots \ldots \ldots \ldots \ldots$ & 19.85 \\
\hline Volatile matter & $\left(\mathrm{Fe}_{2} \mathrm{O} 3\right) \quad \ldots \ldots \ldots \ldots \ldots \ldots$ & absent \\
\hline Alumina oxide & $\left(\mathrm{Al}_{t} \mathrm{O} \mathrm{O} \mathrm{O}\right) \quad \ldots \ldots \ldots \ldots \ldots \ldots$ & 12.00 \\
\hline Silica & $\left(\mathrm{SiO}_{\eta}\right) \quad \ldots \ldots \ldots \ldots \ldots \ldots \ldots \ldots \ldots$ & 66.00 \\
\hline Non-Volatile matte & ter $\ldots \ldots \ldots \ldots \ldots \ldots \ldots \ldots \ldots$ & 584.00 \\
\hline & & 652.00 \\
\hline
\end{tabular}


Public Well, Dade City, Pasco Co. Depth 53 feet; use, public. Analysis by A. W. Blair. 1900. Record p. 92, No. 83 .

Ingredients.

Parts per mill.

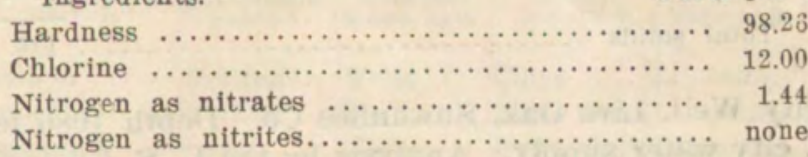

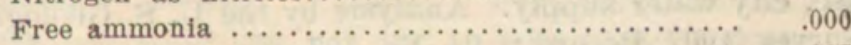

Albuminoid ammonia $\ldots \ldots \ldots \ldots \ldots \ldots \ldots \ldots \ldots \ldots, .015$

Total solids

147.

Muller and Zinsser, Dade City, Pasco Co. Depth 45 feet; use, ice manufacture. Analysis by U. S. Geological Survey. Record p. 92, No. 84 .

Ingredients.

Parts per million.

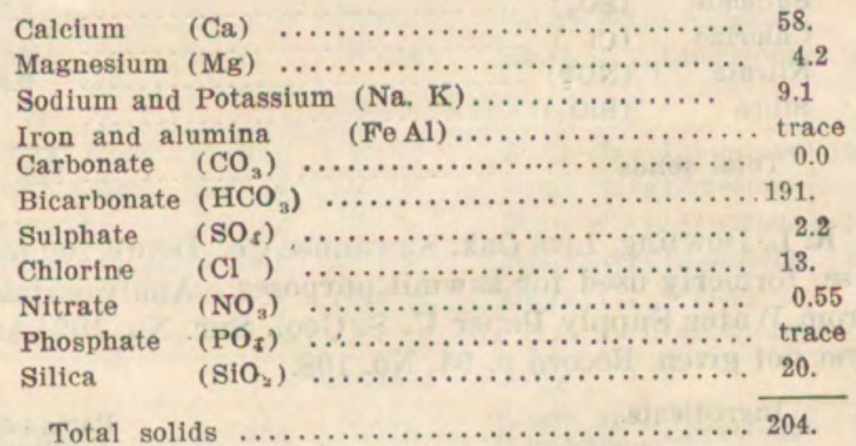

Atlantic Coast Line R. R., Trilby, Pasco Co Depth 31 feet; use, boiler purposes. Analysis by U. S. Geological Survey, 1907. Record p. 92, No. 93.

Ingredients.

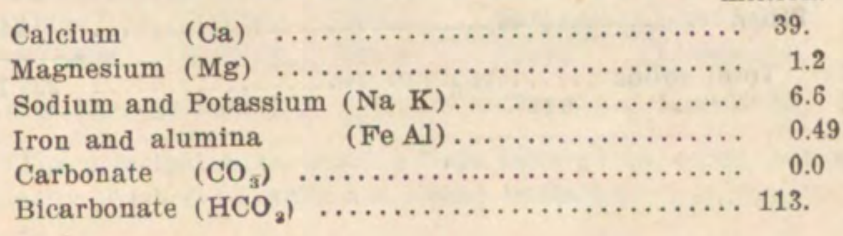

Parts per million. 


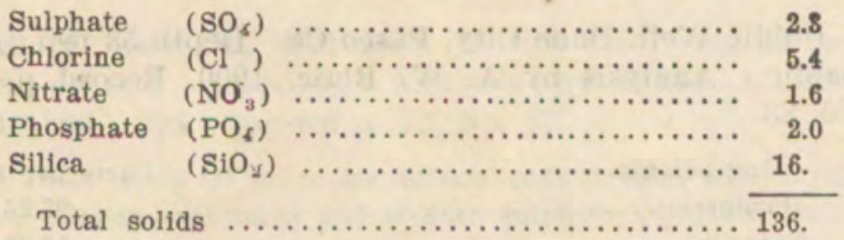

Oity Well, Live Oak, Suwannee Co. Depth 1080 feet; nse, eity water supply. Analysis by the U. S. Geological Survey, 1907. Record p. 94, No. 107.

Ingredients.

Parts per million.

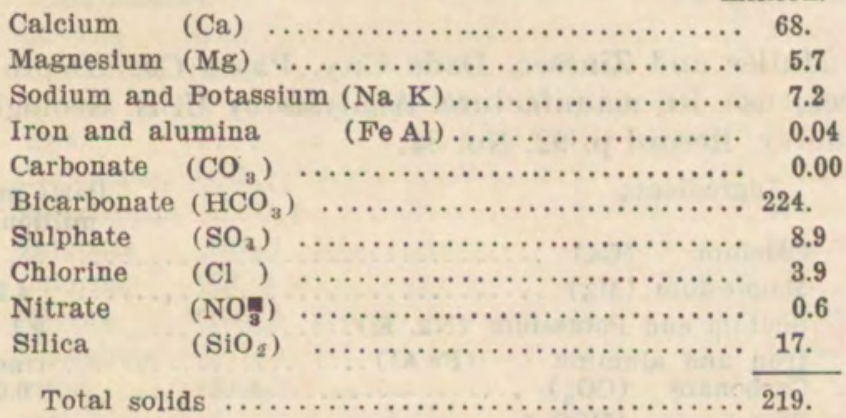

R. L. Dowling, Live Oak, Suwannee Co. Depth 200 feet; use, formerly used for sawmil purposes. Analysis taken from Water Supply Paper U. S. Geol. Sur. No, 102. Analyst not given. Record p. 94, No. 108.

Ingredients.

Parts per million.

Calcium carbonate 163.2

Lime, calcium sulphate.................. 25.5

Magnesium carbonate ................... 14.9

Na. \& Potass. sulphates .................... trace

Na. \& Potass. chlorides................... 17.2

Iron \& Aluminum oxides. . . . . . . . . . . . . .

Silica $\ldots \ldots \ldots \ldots \ldots \ldots \ldots \ldots \ldots \ldots \ldots \ldots \ldots \ldots \ldots, 12.9$

Total solids $\ldots \ldots \ldots \ldots \ldots \ldots \ldots \ldots \ldots \ldots \ldots, 237.2$ 


\section{WATER SUPPLY TABLES.}

General Water Resources.

ALACHÚA COUNTY.

\begin{tabular}{|c|c|c|c|c|c|}
\hline TOWN. & $\begin{array}{c}\text { Topographie } \\
\text { location. }\end{array}$ & $\begin{array}{c}\text { Principal } \\
\text { source water. }\end{array}$ & $\begin{array}{c}\text { Surface } \\
\text { formation. }\end{array}$ & $\begin{array}{c}\text { Principal } \\
\text { water beds. }\end{array}$ & $\begin{array}{l}\text { Depth } \\
\text { deep'st } \\
\text { wells, } \\
\text { feet. }\end{array}$ \\
\hline lachua & r & Wells & Clays .... & Limestone & 216 \\
\hline Archer $\ldots \ldots \ldots$ & Rolling & Wells . & Some clays 1 & Lim & \\
\hline rredonda.. .1 & Level & Wells . & Some clays & Limestone & 125 \\
\hline Clark ........ & Rolling & Wells .... & Some cle & tone. & $t^{2}$ \\
\hline tton ... & Rolling & Wells .... & Some clays. & Limestone & \\
\hline Evinston ..... & Hilly & Wells.... & Some clays & Limestone & 126 \\
\hline Gainesville & Rolling ... & Wells ... & Clays & Limestone. & 347 \\
\hline Hague .... & Rolling ... & Wells ... & Clays & Limestone & $\sqrt{3}$ \\
\hline Hawthorn & Rolling ... & Wells .. & Clays. & Limestone & (6) \\
\hline High Springs.. & Rolling .. & Wells .. & Some clays & Limestone. & 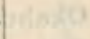 \\
\hline Island Gro & Rolling .. & Wells .. & Some clays & Limestone & ming $=$ \\
\hline Micanopy & Rolling .. & Wells .. & Clays .... & Limestone & 151 \\
\hline Newberry & Rolling ... & Wells . . & Sandy elay & Limestone & 123 \\
\hline Rochelle. & Level .... & Wells. & Sandy clay & Limestone & \\
\hline Waldo ... & Level ... & Wells . & Clays. & Limestone & 55 \\
\hline
\end{tabular}

CITRUS COUNTY.

Crystal River.. Rolling ... Wells ..... Some clay Limestone 1900

Floral City.... Rolling ... Wells .... Some clays Limestone :1

Hernando .... Rolling ... Wells .... Some clays Limestone 153

Holder ...... Rolling ... Wells .... Some clays Limestone 130

Inverness .... Rolling ... Wells .... Clays .... Limestone 90

Lecanto ..... Rolling .. Wells .... Clays .... Limestone 125

COLUMBIA COUNTY.

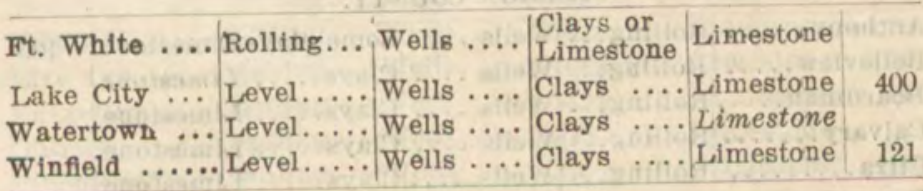

HAMILTON COUNTY.

Jasper ....... Rolling... Wells .... Sandy clay Limestone 450

Jennings ..... Rolling... Wells .... Some clays Limestone

West Lake.... kolling... Wells .... Clays .... Limestone

White Springs Rolling... $\begin{aligned} & \text { Wells and } \\ & \text { spring..... Clays ... }\end{aligned} \mid$ Limestone 236

*The principal water-bearing beds believed to occur but not actually reached by wells are placed in italics. 
FLORIDA GEOLOGICAL SURVEY.

General Water Resources-Contimued.

HERNANDO COUNTY.

\begin{tabular}{|c|c|c|c|c|c|}
\hline Town. & $\begin{array}{l}\text { Topographic } \\
\text { location. }\end{array}$ & $\begin{array}{r}\text { Prin } \\
\text { source }\end{array}$ & $\begin{array}{r}\text { Su } \\
\text { forn }\end{array}$ & & $\begin{array}{l}\text { Depth } \\
\text { deep'st } \\
\text { well } \\
\text { (feet). }\end{array}$ \\
\hline 00. & & Wells & & & 6 \\
\hline
\end{tabular}

\section{LAKE COUNTY.}

Altoona....... Level..... Wells .... Clays..... Limestone Astor. ....... Level..... Wells .... Cluys..... Limestone Eustis....... Rolling... Wells .... Clays..... Limestone Grand Island. Rolling... Wells ..... Clays...... Limestone Leesburg...... Rolling... Wells .... Clays..... Limestone Mount Dora... Hilly..... Wells .... Clays..... Limestone Okahumpka... Rolling... Wells .... Clays ... Limestone Sorrento...... Rolling... Wells .... Clays..... Limestone Tavares....... Level..... Wells .... Clays..... Limestone Umatilla..... Rolling... Wells .... Clays..... Limestone

LEVY COUNTY.

Albion........ Roliıng... Wells .... Some clays Limestone

Bronson....... Level..... Wells .... Clays.... Limestone Cedar Key.... Hilly..... Wells .... Ellzey....... Lsvel.... Wells .... Clays..... Limestone Judson........ Rolling... Wells ..... Some clays Limestone Levyville...... Level..... Wells .... Some clays Limestone Otter Creek... Level..... Wells .... Clays..... Limestone Williston..... Rolling... Wells ....

MARION COUNTY.

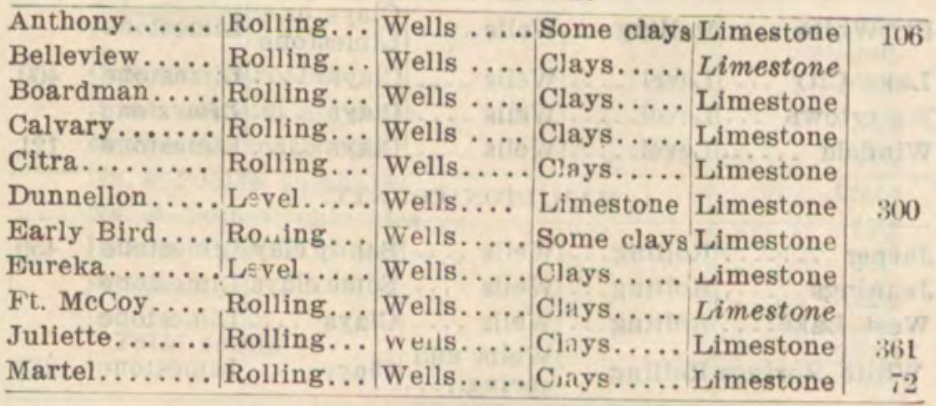

*The principal water-bearing beds believed to occur but not actually reached by wells are placed in italics. 
General Water Resources-Continued.

MARION COUNTY-Continued.

\begin{tabular}{l|l|l|l|l|r}
\hline Ocala......... & Rolling... & Wells..... & Ciays..... & Limeston & 1250 \\
Orange Spring. & Level..... & Wells..... & & Limestone & \\
Reddick....... & Rolling... & Wells.... & Clays.... & Limestone & \\
Rock Sirings.. & Rolling... & Wells .... & Some clay. & Limestone & 78 \\
Silver Spring. & Level..... & Wells ..... & Limestone. & 507 \\
Sparr........ & Rolling... & Wells..... & Some clay & Limestone & 132 \\
\hline
\end{tabular}

PASCO COUNTY.

Dade City.....Rolling... Wells..... Clays..... Liniestone Hudson...... Level..... Wells..... Clays..... Limestone Lacoochee..... Rolling... Weıs..... Some clays Limestone Pasco......... Rolling... Wells.... Some clays Limestone Richland...... Rolling... Wells.... Some clay . Limestone San Antonio... Hilly ..... Wells.... Clays..... Limestone St. Leo....... Hilly ..... W w wls..... Clay s..... Limestone Trilby ....... Level..... Wells..... Clays..... Limestone

SUMTER COUNTY.

Center Hill. . Rolling... Wells..... Some clays Limestone Coleman...... Rolling... wells.... Some clays Limestone n.... .... Rolling... Wells..... Some clays Limestone tanasoffkee... Level.... Wells..... Some clays Limestone Sumterville... Rolling... Wells..... Some clays Limestone Webster...... Level..... Wells..... Some clays Limestone Wildwood..... Level.... Wells..... Some clays Limestone SUWANNEE COUNTY.

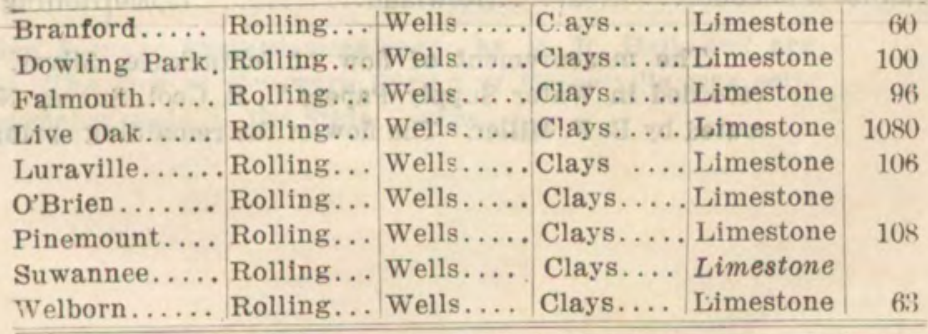

*The principal water-bearing beds believed to occur but not actually reached by wells are placed in italics. 


\section{SPRINGS.}

\begin{tabular}{|c|c|c|c|c|c|}
\hline County. & $\begin{array}{l}\text { Nearest Town } \\
\text { or Postoffice. }\end{array}$ & $\begin{array}{l}\text { Direction } \\
\text { and } \\
\text { Distance. }\end{array}$ & Name of Spring. & $\begin{array}{c}\text { Flow. } \\
\text { Gals, } \\
\text { per } \\
\text { Min. }\end{array}$ & $\begin{array}{l}\text { raphio } \\
\text { aints. }\end{array}$ \\
\hline & 1le... & $2 \mathrm{mi}, \mathrm{se}$. & Boul & 175 & s \\
\hline Alachua. . & Hawthorn... & $4 \mathrm{mi}$. sw. & Magnesia.... & 2,500 & Swampy \\
\hline Alachua.. & High Sp'gs... & 3 mi. w... & Poe $\quad \ldots \ldots \ldots \ldots$ & 44,760 & Hamm \\
\hline Alachua.. & Melrose..... & $\frac{1}{2} \mathrm{mi} . \mathrm{se} .$. & Ford Spg.......... & & Low $\mathrm{h}$ \\
\hline Citrus.... & Crystal Rvr. . & $\frac{1}{\mathrm{mis}} \mathrm{s} . .$. & Crystal River..... & 200,000 & Swamp \\
\hline Citrus.... & Homs & $7 \mathrm{mi} . \mathrm{s} . .$. & Chesehouiska... & $\ldots \ldots$ & $\ldots \ldots$ \\
\hline Columbia. & Ft. W & $6 \mathrm{mi} . \mathrm{nw}$. & ee....... & 180,000 & $\mathrm{H}$ \\
\hline Iamilton. & White Sp'gs. & Near.... & White Sul. Spgs... & 32,400 & Bank o \\
\hline Iernando. & Bay Port.... & $8 \mathrm{mi} . \mathrm{se}$. & Weekiwachee Spgs & 100,000 & Sar \\
\hline ernando. & Bay Port.... & $2 \mathrm{mi}$. ne. & Sulphur.......... & .. & Sy \\
\hline Lake..... & Okahumpka. & $\frac{1}{4}$ mi.n. . & Bug & 1,500 & Sandy. \\
\hline Lake...... & Sorrento.... & $2 \frac{1}{2} \mathrm{mi} . \mathrm{ne}$ & aole.......... & 25,200 & Sandy. \\
\hline Levy..... & Bronson..... & $3 \frac{1}{2} \mathrm{mi}, \mathrm{w}$. & Blu & 25,000 & Swampy ba \\
\hline Levy...... & Otter Creek. & $\ldots \ldots$ & Wekiva.. & 35,395 & Pine \\
\hline evy..... & Otter Creek. & $10 \mathrm{mi} . e$. & Sulp & 5,000 & Swampy. \\
\hline evy..... & Levyville.. & $12 \mathrm{mi} . \mathrm{w}$. & Manatee. . & $\cdots \cdots$ & Rolling. \\
\hline arion...: & Juliette. & Near.... & Blu & 349,166 & Rolling \\
\hline Marion... & Norwalk & 3 mi. w.. & $\mathrm{Sa}$ & 84,000 & Rolling \\
\hline arion... & Silver Spring & Near... & Silver & 368,913 & Level. \\
\hline Sumter... & Sumterville.. & a mi.n.. & Branch Mill Spg... & 21,759 & Rol \\
\hline Suwannee & Suwannee... & $1 \mathrm{mi} . \mathrm{ne}$. & łuwannee Sulphur & 19,747 & Rolling he \\
\hline Suwar & & & Newland......... & 75,000 & Rolling... \\
\hline
\end{tabular}

The measurement of flow of Ichtucknee, Silver, Blue, and recorded in Water Supply Papers U. S. Geol. Survey No. 102 and mated by B. F. Miller. The flow of the remaining springs is based 
SPRINGS.

\begin{tabular}{|c|c|c|c|}
\hline Use of Spring. & Owner of Spring. & & Nature of Stream. \\
\hline $\begin{array}{l}\text { City supply } \\
\text { Drinking.... } \\
\text { Bathing.... } \\
\text { Drinking... } \\
\text { Ice mfg.... } \\
\text { Not used... } \\
\text { Not used... } \\
\text { Resort...... } \\
\text { Not used... } \\
\text { Not used... } \\
\text { Not used... } \\
\text { Not used.... } \\
\text { Not used... }\end{array}$ & 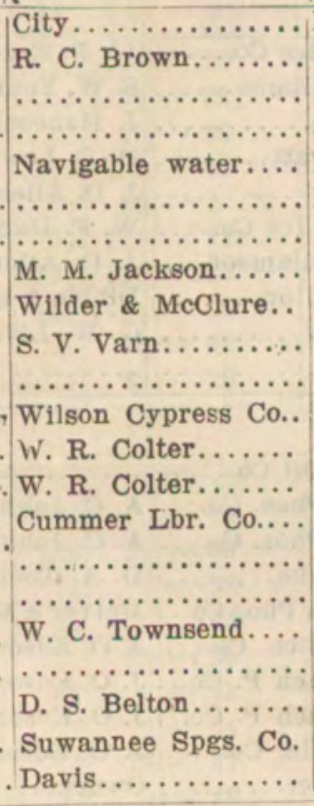 & $\begin{array}{l}\text { Partly soft.... } \\
\text { Some sulphur. } \\
\text {............. } \\
\text { Some sulphur. } \\
\text { Hard, clear... } \\
\text { Hard, clear... } \\
\text { Hard, clear. } \\
\text { Sulphur...... } \\
\text { Hard, clear... } \\
\text { Sulphur....... } \\
\text { Hard, clear... } \\
\text { Partly hard... } \\
\text { Hard, clear... } \\
\text { Hard, clear... } \\
\text { Sulphur....... } \\
\text { Hard, clear... } \\
\text { Hard, clear... } \\
\text { Salfne....... } \\
\text { Hard, clear... } \\
\text { Hard, clear... } \\
\text { Sulphur....... } \\
\text { Hard, clear. }\end{array}$ & $\begin{array}{l}\text { Stream to Lake Harris. } \\
\text { Small stream. } \\
\text { Head Weklva River. } \\
\text { Small stream. } \\
\text { Enters Suwannee River. } \\
\text { Head Wekiva Creek. } \\
\text { Enters Lake George. } \\
\text { Head Silver Springs Run } \\
\text { Small stream. } \\
\text { Enters Suwannee Rlver. }\end{array}$ \\
\hline
\end{tabular}

Suwannee Sulphur Springs were made by M. R. Hall, and are No. 204. The flow of Boulware Spring at Gainesville was estiupon estimates made by the State Survey. 


\section{Wells.}

ALACHUA

\begin{tabular}{|c|c|c|c|c|}
\hline No. & $\begin{array}{l}\text { Nearest Town } \\
\text { or P. O. }\end{array}$ & $\begin{array}{l}\text { Direction } \\
\text { and } \\
\text { Distance. }\end{array}$ & Owner of Well. & Driller. \\
\hline$\overline{1}$ & Alachua..... & $\frac{1}{2} \mathrm{mi} . \mathrm{s} . \ldots$ & Alachua Ice Co...... & W. F. Hamilton..... \\
\hline 2 & Alachua. & $\frac{1}{8} \mathrm{mi} . \mathrm{s} .$. & F. E. Williams...... & S. W. Young......... \\
\hline 3 & Archer... & Near..... & S. A. L...... & J. Hancock......... \\
\hline 4 & Clyatt....... & $\ldots \ldots \ldots$ & F. H. Clyatt... & H. D. Lewis... \\
\hline 5 & Gainesville... & $2 \mathrm{ml} . \mathrm{se} .$. & City.......... & J, D. Allen....... \\
\hline 6 & Gainesville... & 3 blks. nw & Diamond Ice Co..... & W. F. Hamilton..... \\
\hline 7 & Gainesville... & 1 mi.n.... & B. F. Williamson... & J. D. Allen......... \\
\hline 8 & Micanopy.... & $\frac{1}{2} \mathrm{mi} . \mathrm{n} . .$. & C. E. Melton ....... & Dibble \& Earnest... \\
\hline 9 & Newberry.... & Near..... & C. D. May..$\ldots \ldots \ldots$ & G. W. Livingston... \\
\hline 10 & Rochelle.... & Near..... & A. C. L........ & $\cdots \cdots$ \\
\hline
\end{tabular}

\section{CITRUS}

11 Crystal River. 2 mi. n... Pearson Oil Co $\ldots \ldots \ldots \ldots \ldots \ldots \ldots \ldots$

12 Floral City... 1 mi. w... Bradley Phos. Co....

A. C. Johnson.......

13 Floral City... $1 \frac{1}{t} \mathrm{ml}$. w.. Bradley Phos. Co....

14 Floral City... 2 mi. ne.. D. A. Tooke........

15 Hernando.... $\frac{1}{2}$ mi. s. Dunnellon Phos.Co...

A. C. Johnson.......

D. A. Tooke.

16 Hernando.... 1 mi. nw..

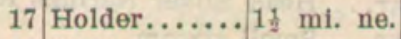

18 Holder......2 2 mi. e....

19 Inverness.... $14 \mathrm{mi}$. w..

20 Lecanto...... 1 mi. n.... W. A. Allen........

McIver \& McKay.

Dutton Phos. Co....

Buttgenbach P. Co..

J. O. Edson

Buttgenbach P. Co...

J. O. Edson.........

J. O. Edson..........

Mutual Min. Co..... J. O. Edson.........

COLUMBIA

\begin{tabular}{|c|c|c|c|}
\hline 21 & ..Near..... & E. M. Curington... & C. M. Ray .......... \\
\hline 22 & . Near.... & W. H. Allen....... & C. M. Ray... \\
\hline 23 & Ft. White.... & M. E. Parsonage..... & C. M. Ray... \\
\hline 24 & Lake City.... $\frac{1}{\frac{1}{1}} \mathrm{mi} . \mathrm{n}$. & City.... & W. F. Hamil \\
\hline 25 & Lake City.... Near.... & City.... & $\cdots$ \\
\hline 26 & Lake City.... 2 mi. w... & J. A. Coombs....... & C. M. Ray... \\
\hline 27 & Lake City.... $10 \mathrm{mi} . \mathrm{s.}$. & H. W. Lamb......... & C. M. Ray......... \\
\hline 28 & Winfield..... ${ }^{\mathbb{3}} \mathrm{m} . \mathrm{s} .$. & J. L. Roberts. & E. H. McIlvane. \\
\hline 29 & Winfield..... & D. G. Rivers....... & C. M. Ray......... \\
\hline 30 & Winfield..... $2 \mathrm{mi}$. w... & Union Church...... & C. M. Ray.... \\
\hline
\end{tabular}

\section{HAMILTON}

31 Jasper...... 1 mi. s... Frank Bamberg..... |R. F. Conine........

32 Jasper...... $6 \mathrm{mi}$ : w: . Jim Bird.......... R. F. Conine.......

33 Jasper...... Near.... City Power Co..... Hugh Partridge..... 


\section{Wells.}

COUNTY.

\begin{tabular}{|c|c|c|c|c|c|c|c|c|c|}
\hline 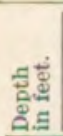 & 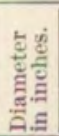 & 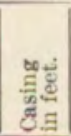 & 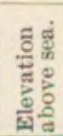 & 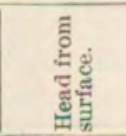 & Use of Well. & $\begin{array}{l}\text { Mir } \\
\text { Cha } \\
\text { of }\end{array}$ & $\begin{array}{l}\text { eral } \\
\text { Nacter } \\
\text { Nater. }\end{array}$ & 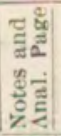 & No. \\
\hline 216 & 6 & $\ldots$. & $\ldots$ & -106 & Ice $\operatorname{mfg} . . . \ldots \ldots$ & Hard & $\ldots$ & 76 & 1 \\
\hline 60 & 2 & $\ldots$. & $\ldots$ & -587 & Household....... & Hard & $\ldots \ldots$ & & 2 \\
\hline 61 & 2 & .. & 80 & -40 & General......... & Hard & $\ldots$ & & 3 \\
\hline 62 & 3 & $\ldots$ & 100 & -32 & Irrigation........ & Hard & $\ldots \ldots$ & & 4 \\
\hline 194 & 12 & $\ldots$ &. .82 & -31.32 & City supply..... & Hard & $\ldots \ldots$ & 76 & 5 \\
\hline 316 & 8 & 160 & 176 & -121 & Ice $\mathrm{mfg} . . . . . .$. & Hard & & 76 & 6 \\
\hline 276 & 8 & 150 & 180 & -128 & Mfg. supply..... & Hard & . & 77 & 7 \\
\hline 151 & 6 & 110 & $\ldots$ & -38 & Saw mill....... & Hard & $\ldots \ldots$ & & 8 \\
\hline 113 & 2 & $\ldots$. & 76 & -40 & Household...... & Hard & $\ldots \ldots$ & & 9 \\
\hline 225 & 6 & $\ldots$ & 80 & -10 & Boiler use...... & Hard & $\ldots \ldots$ & & 10 \\
\hline
\end{tabular}

COUNTY.

\begin{tabular}{|c|c|c|c|c|c|c|c|}
\hline 1900 & $\ldots$ & $\ldots$ & $|\ldots|$ & Flows... & & & 78 \\
\hline 140 & 8 & 50 & $\ldots$ & -35 & Phosphate mining & Hard sulph'r & \\
\hline 130 & 2 & 125 & $\ldots$ & -40 & Dr & Hard & \\
\hline 73 & 2 & 73 & $\cdots$ & -36 & $1 . \ldots$ & Hard ... & , \\
\hline 152 & 12 & 70 & 70 & -50 & te mining & Hard & \\
\hline 142 & 10 & - & 65 & -35 & lining & Hard sulp & \\
\hline 100 & 12 & 42 & .. & -45 & $\mathrm{Pr}$ & Hard & \\
\hline 145 & 12 & 72 & $\ldots$ & -54 & $\mathrm{Ph}$ & Hard .. & \\
\hline 127 & 10 & 44 & 75 & -47 & hinin & Hard & \\
\hline 97 & 2 & 97 & $\ldots$. & -89 & Household..... & Hard ....... & \\
\hline
\end{tabular}

COUNTY.

\begin{tabular}{|c|c|c|c|c|c|c|c|c|c|}
\hline 75 & 2 & $\ldots$ & 188 & -60 & General........ & Hard & $\ldots \ldots$ & & 21 \\
\hline 62 & 2 & 51 & 106 & -55 & General........ & Hard & . & & 22 \\
\hline 68 & 2 & 2 & ... & -61 & Household....... & Hard & $\ldots \ldots$ & & 23 \\
\hline 400 & 10 & 100 & 200 & -134 & City supply..... & Hard & sulph'r & 77 & 24 \\
\hline 400 & $\ldots$ & $\ldots$ & $\cdots$ & -120 & City supply...... & Hard & $\ldots \ldots$ & 77 & 25 . \\
\hline 122 & 2 & 122 & . & -110 & Genoral........ & Hard & $\ldots \ldots$ & & 26 \\
\hline 134 & 2 & 134 & ... & -128 & General........ & Hard & $\ldots \ldots$ & & 27 \\
\hline 121 & 2 & 115 & 115 & -70 & General......... & Hald & $\cdots$ & & 28 \\
\hline 108 & 2 & $\ldots$ & 126 & -60 & General......... & Hard & $\cdots$ & & 29 \\
\hline 92 & 2 & 80 & $\ldots$ & -85 & General......... & Hard & $\ldots \ldots$ & & 30 \\
\hline
\end{tabular}

COUNTY.

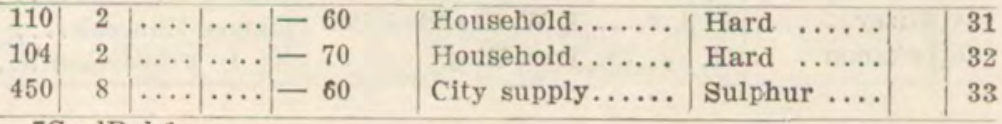

7GeolBul-1 


\section{Wells-Continued.}

HAMILTON

\begin{tabular}{|c|c|c|c|c|}
\hline No. & $\begin{array}{l}\text { Nearest Tøwn } \\
\text { or P. } 0 \text {. }\end{array}$ & $\begin{array}{l}\text { Direction } \\
\text { and } \\
\text { Distance. }\end{array}$ & Owner of Well. & Driller. \\
\hline $\begin{array}{l}34 \\
35\end{array}$ & $\begin{array}{l}\text { Marion...... } \\
\text { White Springs }\end{array}$ & Near..... & $\begin{array}{l}\text { S. Hall } \ldots \ldots \ldots \ldots \ldots \\
\text { Dr. B. F. Camp... }\end{array}$ & Henry Ratcliff...... \\
\hline 36 & White Springs & $1 \mathrm{mi} . \mathrm{nw}$. & Camp Lbr. o........ & Owner..... \\
\hline 37 & White Springs & & N. Adams. . . . . . . . & C. M. Ray ......... \\
\hline 38 & White Springs & $\frac{1}{2}$ mi. n... & G. S. Mobley........ & C. T, Lowe......... \\
\hline 39 & White Springs & Near..... & J. M. Morgan........ & C. T Lowe........... \\
\hline 40 & White Springs & tmi. se... & W. B. Telford....... & E. H. McIlvare..... \\
\hline
\end{tabular}

\section{HERNANDO}

41 Brooksville.

42 Brooksville. .

43 Brooksville. .

44 Brooksville. .

45 Brooksville. .

46 Brooksville..

47 Brooksville..

48 Croom........

49 Istachatta...

50 Rural.......

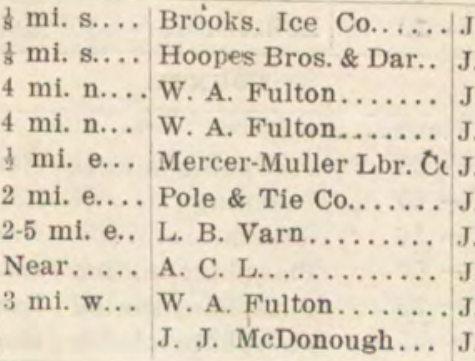

J. D. Allen

J. D. Allen

J. D, Allen

J. D. Allen.

J. D. Allen

J. D. Allen

J. D, Allen.

J. D. Allen

J. D. Allen

J. D. Allen .

\section{LAKE}

51 Astor....... Near.... $\mid$ A. A. Thompson.... $\mid$ S. H. Hoagland.....

52 Eustis...... 7 blks. se.. Dibble \& Earnest.... Dibble \& Earnest....

53 Grand Island Near.... Fla. Fertilizer Co...

54 Leesburg..... Near..... City

Dibble \& Earnest. ...

55 Leesburg. .... 2 mi. w... J. T. Egbert. .......

56 Leesburg..... $\frac{1}{8}$ mi. s.... Leesburg ice Co...... Padgett............ John Heaton

$57 \mid$ Mt. Dora.... $\frac{1}{2}$ mi. nw. S. M. Weld.

John Heaton...........

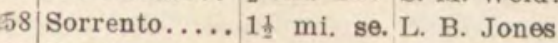

Dibble \& Earnest. ... .

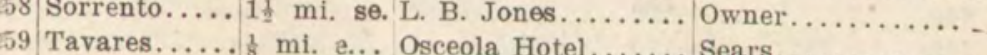

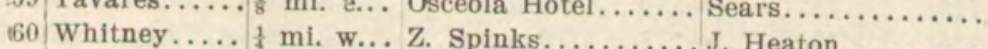

LEVY

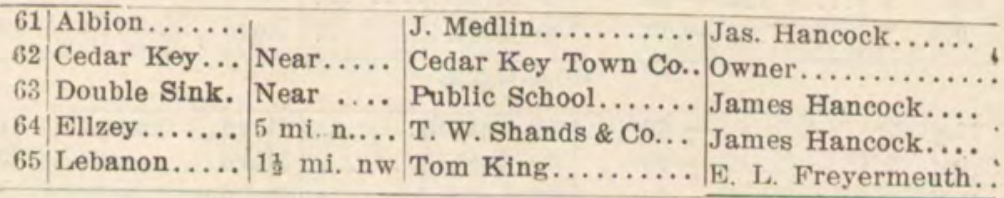


WelLs-Continued. counTy-Continued.

\begin{tabular}{|c|c|c|c|c|c|c|c|c|}
\hline 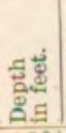 & 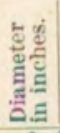 & 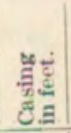 & 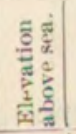 & 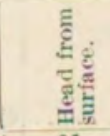 & Use of Well. & $\begin{array}{l}\text { Mineral } \\
\text { character } \\
\text { of water. }\end{array}$ & 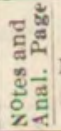 & No. \\
\hline 160 & 2 & $\ldots \ldots$ & $\cdots$ & -60 & & Hard ..... & & 34 \\
\hline 160 & 2 & $\ldots$ & $\ldots$ & -60 & Hoirsehold..... & Hard sulph'r & & 35 \\
\hline 150 & 8 & 100 & $\cdots$ & -50 & Sawmill ........ & Hard sulph'r & & 36 \\
\hline 80 & 2 & 2 & $\ldots$. & -77 & Household....... & Hard $\ldots . .$. & & 37 \\
\hline 157 & 2 & $\ldots$ & $\ldots \ldots$ & -35 & Household. . & Hard ... & & 38 \\
\hline 126 & 2 & .... & & -40 & General. . . . . $\ldots$. & Hard ....... & . & 39 \\
\hline 208 & $\theta$ & 40 &. & -11 & Hotel purposes... & Sulphur .... & & 40 \\
\hline
\end{tabular}

COUNTY.

\begin{tabular}{|c|c|c|c|c|c|c|c|c|c|}
\hline 150 & 8 & 110 & 126 & -103 & Ice $\operatorname{mfg} . . . . . .$. & Hard & $\ldots$ & & 11 \\
\hline 226 & 8 & 79 & 128 & -108 & Sawmill purposes & Hard & . & 78 & 42 \\
\hline 200 & 10 & 50 & $\ldots$ & -8 to 10 & Drainage........ & Hard & $\ldots \ldots$ & & 43 \\
\hline 219 & 10 & 50 & $\cdots$ & $\ldots, \ldots, \ldots$ & Drainage....... & Hard & & & 44 \\
\hline 80 & 4 & 80 & . & $\ldots \ldots \ldots$ & Sawmill......... & Hard & & & 45 \\
\hline 125 & 6 & 40 & $\ldots$ & -60 & General......... & Hard & & & 16 \\
\hline 176 & 6 & ... & $\ldots$ & -126 & Household....... & Hard & & & 7 \\
\hline 75 & 8 & 40 & $\ldots$ & -16 & R. R. boiler use.. & Hard & & & 8 \\
\hline 140 & 10 & .. & . & -8 & Phosphate mining & Hard & .. & & \\
\hline 120 & 8 & 40 & $\ldots$ & -20 & & Hard & $\ldots \ldots$ & & \\
\hline
\end{tabular}

COUNTY.

\begin{tabular}{|c|c|c|c|c|c|c|c|}
\hline 82 & 3 & 75 & 15 & +14 & Hotel............ & Hard sulph'r & 78 \\
\hline 173 & $5 \frac{8}{8}$ & 134 & $\ldots \ldots$ & -62 & Domestic........ & Part soft. . & 78 \\
\hline 186 & 58 & 107 & $\ldots$. & $\ldots \ldots \ldots$ & General.......... & Soft .... & \\
\hline 550 & 2 & $\ldots$. & $\cdots$ & -18 & . ublic........... & Hard ... & \\
\hline 175 & 4 & 84 & $\cdots \cdots$ & -16 & Irrigation....... & Hard.. & \\
\hline 98 & 4 & 95 & 87 & -20 & General......... & Hard .. & 79 \\
\hline 180 & 6 & 114 & $\ldots$. & -60 & Ice mfg. City sup'y & Hard & \\
\hline 103 & 2 & 67 & $\cdots \cdots$ & -70 & Household...... & Part hard .. & \\
\hline 124 & 2 & 124 & 66 & ......... & Hotel........... & Part soft ... & \\
\hline 243 & 3 & 240 & $\ldots$. & -11 & Brick plant...... & Hard $\ldots$ & \\
\hline
\end{tabular}

COUNTY.

\begin{tabular}{|c|c|c|c|c|c|c|}
\hline 60 & 2 & $\ldots$ & $|\ldots|-45$ & & Hard $\ldots . . .1$ & 61 \\
\hline 865 & ... & $\ldots$ & $6-11$ & Abandoned....... & Brackish ... & 62 \\
\hline 52 & 2 & $\ldots$ & $\ldots \ldots-36$ & Drinking......... & Hard ....... & 63 \\
\hline 63 & 2 & $\ldots$ & $\ldots \ldots \mid-10$ & Turpentine still.. & Hard $\ldots \ldots$. & 64 \\
\hline 90 & 2 & 40 & $|\ldots|-9$ & Sawmill purposes & Hard..... & 5 \\
\hline
\end{tabular}




\section{Wells-Continued.}

\section{LEVY}

\begin{tabular}{|c|c|c|c|c|}
\hline No. & $\begin{array}{l}\text { Nearest Town } \\
\text { or P. O. }\end{array}$ & $\begin{array}{l}\text { Dieection } \\
\text { and } \\
\text { Distance. }\end{array}$ & Owner of Well. & Driller. \\
\hline 66 & Levyville.... & Near..... & G. Garter......... & Owner.............. \\
\hline 67 & Montbrook... & & S. Blitch .......... & James Hancock..... \\
\hline 68 & Morriston.... & & P. King. . . . . . . . & James Hancock.... \\
\hline 69 & Morriston.... & & A, C. L. R. R...... & James Hancock..... \\
\hline 70 & Otter Creek. . & $8 \mathrm{mi} . \mathrm{e} . .$. & Fisher \& Shands.... & James Hancock..... \\
\hline 71 & Otter Creek. . & Near..... & OtterCreek Lbr.Co... & \\
\hline 72 & Williston.... & Near...... & Williston Mfg. Co... & John Acre.. \\
\hline
\end{tabular}

MARION

73 Dunnellon... Near.... City ............ J. D. Allen........ 74 Juliette..... $2 \frac{1}{2}$ mi. nw. Dutton Phos. Co.... Hughes Spec.Co....

75 Leroy....... Near.... Public............

77 McIntosh.... Near.... . . . H, Gaitskill...... Furgeson.........

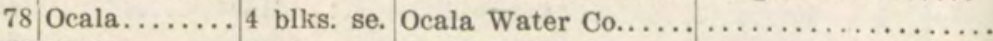

79 Ocala....... 4 blks. se. Ocala Water Co..... E. F. Joyce.........

80 Ocala........ $\frac{1}{4}$ mi. n... Ocala Ice \& Pack. Co W. F. Hamilton.....

81 Rock Springs Near..... Meffert \& Maynard.. E.L.Freyermeuth.... 82 Silver Springs $\frac{1}{4}$ mi. e... E.P.W.Rentz Lbr.Co.. H. F. Lloyd .........

\section{PASCO}

83 Dade City .... Near.... City ..............W. A. Sparkman ...

84 Dade City.... $\frac{1}{2}$ mi. se... Muller \& Zinzser.... W. A. Sparkman....

85 Fivay....... Near..... Aripeka Sawmill.... J. D. Allen........

86 Fivay....... Near..... Aripeka Sawmill.... J. D. Allen.........

87 Odessa....... Near..... Gulf Pine Co....... T. J. Zimmerman....

88 Pasadena.... Near.... The Spencer Well.... N. C. Bryant.......

89 Port Richey. . 4 mi. n... Stubbs Bros. \& Co... . . D. Allen........

90 Richland.... Near..... A. C. L. R. R....... J. D. Allen.........

91 San Antonio. $5 \mathrm{mi} \mathrm{sw...} \mathrm{J.} \mathrm{S.} \mathrm{Flanagan......} \mathrm{W.} \mathrm{A.} \mathrm{Sparkman.....}$

92 St. Leo...... Near..... Dr. J. F Corrigan... Owner. . . . . . . .

93 Trilby ...... Near.... A. C. L. R. R....... W. A. J. Prescotc....

\section{SUMTER}

$94 \mid$ Center Hill... Near..... $\mid$ F. D. Smith ....... J. H. Robbins.......

95 Center Hill... Near.... Venable \& Harkness. J. H. Robbins. . . . . . .

$96 \mid$ Oxford ....... $\frac{1}{4}$ mi. nw.. H. O. Collier....... E.L.Freyermeuth...

$97 \mid$ Oxford ...... Near.... J. F. Javine....... E.L.Freyermeuth... 
Wells-Contimued.

coUNTY-Contimued.

\begin{tabular}{|c|c|c|c|c|c|c|c|c|}
\hline 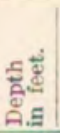 & 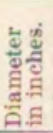 & 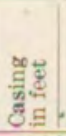 & 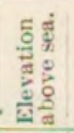 & 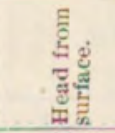 & Use of Well. & $\begin{array}{l}\text { Mineral } \\
\text { character } \\
\text { of water. }\end{array}$ & 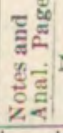 & No. \\
\hline 28 & 2 & 28 & $\cdots \cdots$ & -11 & General. & & & 66 \\
\hline 52 & 2 & 42 & $\ldots \ldots$ & -23 & & Hard.... & & 67 \\
\hline 43 & 2 & 40 & $\cdots \cdots$ & -16 & & Hard ...... & & 68 \\
\hline 90 & 5 & 40 & $\ldots$. & -18 & R. R. boiler ust.. & Hard ... & & 69 \\
\hline 80 & 2 & 79 & $\cdots$ & -7 to 8 & Turpentine still. & Hard.... & & 70 \\
\hline 85 & 4 & $\cdots$ & 29 & -8 & Sawmill........ & Hard.... & 79 & 71 \\
\hline 60 & 4 & 22 & $\ldots$ & -20 & ice mfg... & $\operatorname{Har}_{d} \ldots .$. & 79 & 72 \\
\hline
\end{tabular}

COUNTY.

\begin{tabular}{|c|c|c|c|c|c|c|c|c|}
\hline 155 & 6 & 90 & 50 & -20 & City supply...... & Hard...$\cdots$ & & 78 \\
\hline 796 & 14 & 280 & 90 & -54 & Phosphate mining & Hard..... & & 74 \\
\hline 46 & 2 & $\ldots$. & 85 & -42 & Public.......... & Hard .. & & 75 \\
\hline 65 & 2 & 50 & 77 & -40 & Domestic........ & & & 76 \\
\hline 54 & 2 & 45 & 65 & -27 & Domestic.... & Hard & 80 & 77 \\
\hline 190 & 12 & & $\cdots$ & -72 & City supply..... & Hard ...... & 80 & 78 \\
\hline 1250 & 8 & $\because \ldots$ & 100 & -70 & City supply...... & Hard sulph'r & 80 & 79 \\
\hline 172 & 42 & 172 & 65 & -21 & .ce $\operatorname{mfg} . . . \ldots \ldots$ & Hard . & & 80 \\
\hline 78 & $2 \frac{1}{2}$ & 78 & 70 & -30 & Sawmill and still. & Hard & & 1 \\
\hline 507 & 2 & $\cdots$ & 45 & -5 & Sawmill purposes & Hard sulph'r & & 82 \\
\hline
\end{tabular}

\begin{tabular}{|c|c|c|c|c|c|c|c|c|c|}
\hline 53 & 2 & 50 & $\cdots$ & -35 & Public........... & Hard & $\ldots \ldots$ & 81 & 83 \\
\hline 45 & 6 & 45 & 88 & -17 & Ice $\mathrm{mfg} . . . . . .$. & Hard & $\ldots \ldots$ & 81 & 84 \\
\hline 96 & 6 & 40 & $\ldots$ & -6 & Sawmill purposes & Hard & $\ldots \ldots$ & & 85 \\
\hline 120 & 6 & 40 & $\ldots$ & -8 & Sawmill purposes & Hard & $\ldots \ldots$ & & 86 \\
\hline 104 & 4 & 35 & 57 & -11 & Sawmill purposes & Hard & $\ldots \ldots$ & & 87 \\
\hline 300 & 8 & 170 & $\ldots$ & -86 & & Hard & $\ldots \ldots$ & & 88 \\
\hline 147 & 6 & 30 & $|\cdots|$ & -14 & Turp. still supply & Hard & $\ldots \ldots$ & & 89 \\
\hline 90 & 8 & $\cdots \cdots$ & 93 & -30 & R. R boiler $u=e$. & Partly & hard. & & 90 \\
\hline 85 & 5 & 82 & $\ldots$ & -80 & Irrigation......... & Hard & $\ldots \ldots$ & & 91 \\
\hline 75 & 3 & 71 & 191 & -32 & Domestic........ & Hard & $\ldots \ldots$ & & 92 \\
\hline 31 & 10 & 19 & 29 & - 5 & R. R. boiler use.. & Hard & $\cdots \cdots$ & 81 & 93 \\
\hline \multicolumn{10}{|c|}{ COUNTY. } \\
\hline 55 & $1 \frac{1}{8}$ & 45 & & -10 & Irrigation........ & Hard & & & 94 \\
\hline 55 & 4 & 40 & 93 & -14 & Public........... & Partly & hard. & & 95 \\
\hline 86 & 2 & 80 & 100 & -50 & General........... & Hard & $\cdots \cdots$ & & 96 \\
\hline 76 & 2 & 60 & 100 & -52 & General ......... & Hard & $\ldots \ldots$ & & 97 \\
\hline
\end{tabular}


WeLls-Continued.

SUMTER

\begin{tabular}{|c|c|c|c|c|}
\hline No. & $\begin{array}{l}\text { Nearest Town } \\
\text { or P. O. }\end{array}$ & $\begin{array}{l}\text { Directisn } \\
\text { and } \\
\text { Distance. }\end{array}$ & Owner of Well. & Driller. \\
\hline 98 & Oxford. & $1 \mathrm{mi} . \mathrm{s} . .$. & J. S. Reese & E.L.Freye \\
\hline 99 & Oxford... & Near..... & Sunset Crate\&Lbr.Co & W. F. Ha \\
\hline 100 & Sumterville.. & Near..... & City $\ldots \ldots \ldots \ldots$ & B. F. Smith ......... \\
\hline 101 & Sumterville. . & $2 \frac{1}{2} \mathrm{mi}$. s.. & Pearfon Oil Co...... & \\
\hline 102 & Webster.... & Near..... & r. W. Fussell........ & C. L. Eaddy........ \\
\hline 103 & Webster..... & $\frac{1}{8} \mathrm{mi} . \mathrm{w} . .$. & W B. Ki & J. H. Rol \\
\hline \multicolumn{5}{|c|}{ SUWANNEE } \\
\hline 4 & Bra & 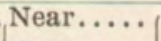 & ig Co.. & W. A. Gaston. . \\
\hline 105 & Dowling Park & Near..... & H. J. Cannon......... & P. W. Warren. . \\
\hline 06 & Falmouth.... & $\frac{1}{2} \mathrm{mi} . \mathrm{sw} .$. & F. W. Millinor \& Co.. & W. B. Hicks. ... . \\
\hline 107 & Live Oak. . & 4 blks. s.. & City ................. & $\ldots \ldots \ldots \ldots \ldots$ \\
\hline 08 & Live Oak.. & $1 \mathrm{mi} . \mathrm{nw} .$. & R. L. Dowling...... & $\ldots \ldots \ldots \cdots$ \\
\hline 109 & Live Oak. & 9 mi. nw.. & W. R. Jenkins..... & W. B. Hicks. . \\
\hline 10 & Live $\mathrm{Oa}$ & $7 \frac{1}{2} \mathrm{mi} \cdot \mathrm{nw}$ & W. A. Nobles... & Tucker............ \\
\hline 11 & Luraville. & $1 \mathrm{mi} . \mathrm{n} \ldots$ & Neutral Mining Co... & S. W. Young........ \\
\hline 12 & Pinemour & Near..... & F. M. Green........ & H. Clanton........... \\
\hline 13 & Welborn. & & & C. M. Ray......... \\
\hline
\end{tabular}

\section{Public Water Supplies.}

\begin{tabular}{|c|c|c|c|c|c|c|c|c|}
\hline \multirow{2}{*}{ COUNTY. } & \multirow{2}{*}{ TOWN. } & \multirow[b]{2}{*}{ Source. } & \multirow[b]{2}{*}{ Ownership. } & \multicolumn{3}{|c|}{ Wells. } & \multirow{2}{*}{$\begin{array}{l}\text { Relation } \\
\text { to Town. }\end{array}$} & \multirow{2}{*}{$\begin{array}{l}\text { Standpipe } \\
\text { capacity. }\end{array}$} \\
\hline & & & & No. & Diam. & Depth & & \\
\hline Alachua.. & Gain'sville & Well, Spg. & Public.... & 1 & 12 & 194 & $90 \mathrm{ft}$. lower & none \\
\hline Columbia. & Lake City & Well... & Public.... & 1 & 10 & 400 & samr: level & none \\
\hline Hamilton. & Jasper. . & Well... & Private... & 1 & 8 & 450 & same level & 50,000 \\
\hline Lake..... & Leesburg. & Wells.. & Private... & 3 & $2 \frac{1}{2}$ & $\begin{array}{c}98 \\
\text { to } \\
101\end{array}$ & same level & 20,000 \\
\hline Marion... & Dunnellon & Well... & Public.... & 1 & 8 & 155 & same level & 40,000 \\
\hline Marion... & Ocala.... & Wells.. & Private... & 2 & $\begin{array}{r}12 \\
8\end{array}$ & $\begin{array}{r}190 \\
1250\end{array}$ & same level & 112,000 \\
\hline Suwannee & Live Oak. & Well... & Public.... & 1 & 6 & 1080 & same level & 85,000 \\
\hline
\end{tabular}


Wells-Contimued.

cOUNTY-Continued.

\begin{tabular}{|c|c|c|c|c|c|c|c|c|}
\hline 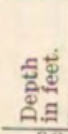 & 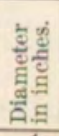 & 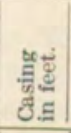 & 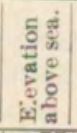 & 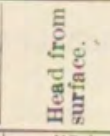 & Use of Well. & $\begin{array}{c}\text { Mineral } \\
\text { Character }\end{array}$ & 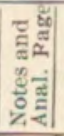 & No. \\
\hline 92 & 4 & $\cdots$ & 77 & $-31 t$ & Irrigation........ & Hard..... & & 98 \\
\hline 74 & 4 & $\cdots$ & 100 & -55 & Gen. mill purpose & Hard $\ldots . .$. & & $9 y$ \\
\hline 86 & $1 \frac{1}{2}$ & $\cdots \cdots$ & $\cdots$ & -21 & General.......... & Hard ...... & & 100 \\
\hline 2002 & 10 & $\cdots$ & $\cdots$ & -5 & & Hard sulph'r & & 101 \\
\hline 132 & 2 & 130 & $\ldots$ & -8 & General... & Hard $\ldots . .$. & & 102 \\
\hline 50 & 4 & 30 & 89 & -5 & Irrigation. & Hard $\ldots \ldots$ & & 103 \\
\hline \multicolumn{9}{|c|}{ COUNTY. } \\
\hline 60 & 2 & 45 & 43 & -25 & Ginning purposes & Hard..... & & |104 \\
\hline $91 \frac{1}{2}$ & 2 & $91 \frac{1}{2}$ & $\cdots$ & -25 & Livery stable.... & Sulphur $\ldots$ & & 105 \\
\hline 84 & 3 & 60 & $\ldots$ & -65 & Turpentine still.. & Hard ...... & & 106 \\
\hline 1080 & 6 & $\cdots$ & 110 & -50 & City supply...... & Hard ...... & 82 & 107 \\
\hline 200 & 6 & $\cdots$ & $\cdots$ & -44 & Sawmill......... & Hard.... & 82 & 108 \\
\hline 70 & 2 & 67 & $\cdots$ & -60 & Sawmill purposes & Hard..... & & 109 \\
\hline $98 \frac{1}{2}$ & 2 & 85 & $\ldots$ & -63 & General.......... & Hard $\ldots .$. & & 110 \\
\hline 95 & 8 & 47 & $\cdots$ & -32 & sosphate mining & Hard $\ldots \ldots$ & & 111 \\
\hline 87 & 2 & 87 & $\ldots$ & -73 & Mill purposes.... & Hard ...... & & 112 \\
\hline 80 & 2 & 70 & $\ldots$ & -68 & Household....... & Hard ...... & & 113 \\
\hline
\end{tabular}

Public Water Supplies.

\begin{tabular}{|c|c|c|c|c|c|}
\hline 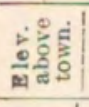 & 暨点 & 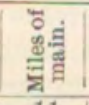 & Character of Water. & Sewage Disposal. & $\begin{array}{l}\text { Notes and } \\
\text { Analyses. }\end{array}$ \\
\hline$\cdots \cdots$ & $\begin{array}{l}92 \\
\cdots\end{array}$ & $\begin{array}{c}11 \\
6 \text { to } 8\end{array}$ & $\begin{array}{l}\text { Hard, soft........ } \\
\text { Hard, slightly }\end{array}$ & Septic tank $\ldots \ldots \ldots \ldots \ldots \ldots$ & P. 70,76 \\
\hline 50 & 10 & 1 & $\begin{array}{r}\text { sulphur......... } \\
\text { Sulphur, hard.... }\end{array}$ & Septic tank $\ldots \ldots \ldots \ldots \ldots \ldots$ & P. 77 \\
\hline 60 & 12 & $2 \frac{1}{2}$ & Medium hard..... & No sewage system..$\ldots \ldots \ldots$ & P. 79 \\
\hline 80 & 91 & 9 & Hard............. & No sewage system......... & \\
\hline 30 & 5 & 2 & Hard............ & Bored wells and cesspools... & P. 92 \\
\hline 83 & 371 & 5 & & Bored wells and cesspools... & P. 82 \\
\hline
\end{tabular}




\section{INDEX.}

Page

Alabama, Geological Survey of, referred to............. 8

Acids, formation of hydrogen sulphides by ............. 20

Alachua County, sketch showing water level in .......... 4 J

general water resources of $\ldots \ldots \ldots \ldots \ldots \ldots \ldots \ldots \ldots \ldots . \ldots \ldots$

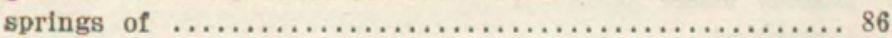

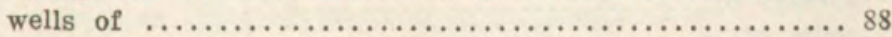

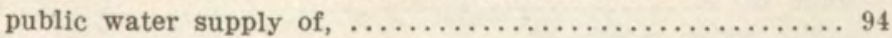

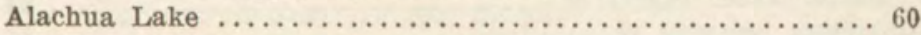

Alachua savanna, described by Bartram, ............ 59

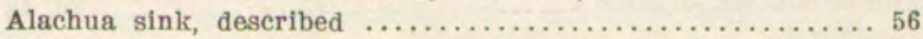

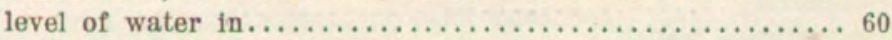

Alumina removed in solution....................... 48

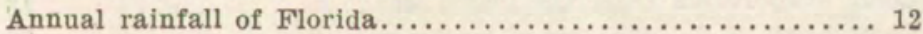

Artesian areas, map of, (facing) ................... 44

Artesian water, hydrogen sulphide in, ................ 23

Bacteria, effect of septic tank on ....................66

Bacillus typhosus, effect of septic tank on, ............66

Bartram, William, cited on formation of sinks.........52, 59

Blair, A. W., water analyses by, $\ldots \ldots \ldots \ldots \ldots \ldots \ldots \ldots .25,74,81$

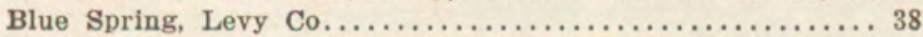

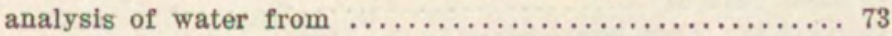

amount of mineral solids removed by .............. 47

Blue Springs, Marion County, relation of, to underground

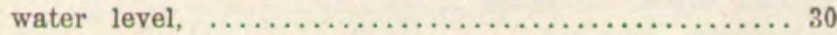

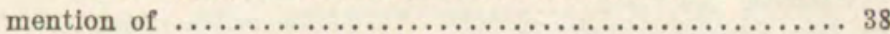

amount of mineral solids removed by .............. 47

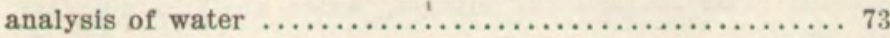

Boulware Spring, analysis if water from $\ldots \ldots \ldots \ldots \ldots \ldots 7 \mathrm{v}$

Cairns, G. D., levels made by, .................... 30

Calcium carbonate removed in solution................ 48

Capillary attraction, water returned to the surface by ...... 15

Capillary water in soils............................. 24

Carbon dioxide, abundance of, in deep waters............ 21

effect of, on solubility of calcium carbonate........... 33

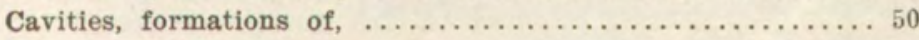

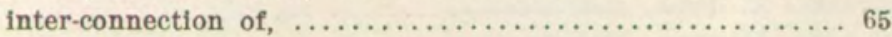

Central Florida, topography of..................... 9

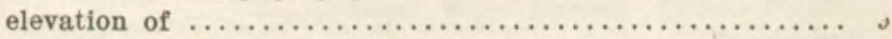

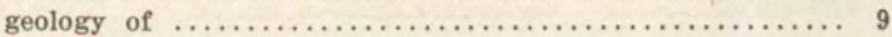

annual rainfall of $\ldots \ldots \ldots \ldots \ldots \ldots \ldots \ldots \ldots \ldots \ldots \ldots \ldots \ldots \ldots$

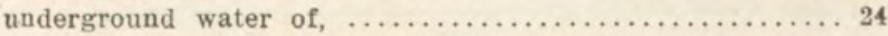


Tho

Page.

Chandler, C. H., water analysis by $\ldots \ldots \ldots \ldots \ldots \ldots \ldots \ldots \ldots \ldots$

Chesehouiska Springs $\ldots \ldots \ldots \ldots \ldots \ldots \ldots \ldots \ldots \ldots \ldots \ldots$

Citrus County, general water resources of............. 83

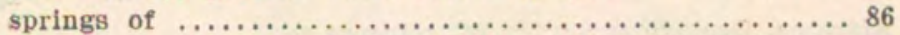

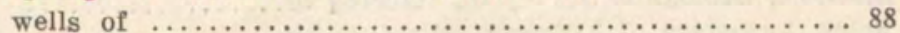

Columbia County, sketch illustrating underground water level

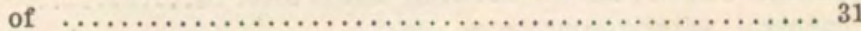

general water resources of, $\ldots \ldots \ldots \ldots \ldots \ldots \ldots \ldots \ldots .83$

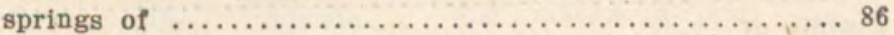

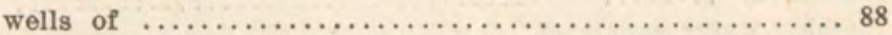

public water supply of $\ldots \ldots \ldots \ldots \ldots \ldots \ldots \ldots \ldots \ldots \ldots . \ldots 4$

Chlorides removed in solution................... 48

Contamination, organic $\ldots \ldots \ldots \ldots \ldots \ldots \ldots \ldots \ldots \ldots \ldots, 42$

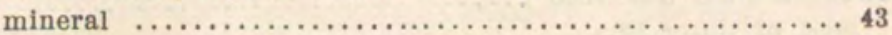

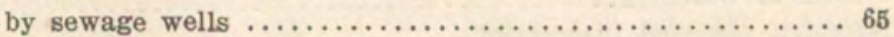

Corn, evaporation from the leaves of, .............. 16

Crowbaugh, T. L., analysis of water by ........... 79

Crystal River Spring ................................ 38

Dall, W. H., cited on Tampa Limestone.............. 11

Deposition and replacement $\ldots \ldots \ldots \ldots \ldots \ldots \ldots \ldots \ldots \ldots \ldots$

Devil's Mill Hopper, described................... 29

Dickoie, W., analyses of water by $\ldots \ldots \ldots \ldots \ldots \ldots \ldots \ldots, 71$

Disappearing streams, described $\ldots \ldots \ldots \ldots \ldots \ldots \ldots \ldots \ldots, 53$

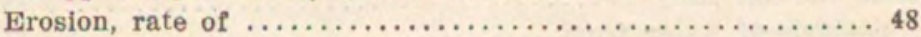

Evaporation, from the surface of the earth ............ 13

from the leaves of plants..................... 15

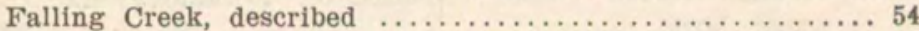

Flatwoods, described $\ldots \ldots \ldots \ldots \ldots \ldots \ldots \ldots \ldots \ldots \ldots, 9$

Florida, annual rainfall of . . . . . . . . . . . . . . 12

Florida State Experiment Station, water analyses supplied

by, $\ldots \ldots \ldots \ldots \ldots \ldots \ldots \ldots \ldots \ldots \ldots \ldots \ldots \ldots \ldots \ldots \ldots \ldots \ldots \ldots \ldots \ldots \ldots \ldots \ldots \ldots \ldots, 25$

Foraminifera in Vicksburg limestone.............. 10

Ford Spring, analysis of water from, . . . . . . . .

Fuller, M. L., cited on sources of underground water....... 12 cited on inter.connection of cavities in the limestone.....65

Gainesville, well records of ........................ 30

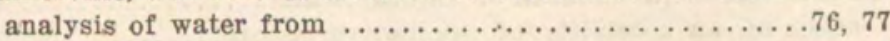

Georgia, Geological Survey of, referred to.............. 8

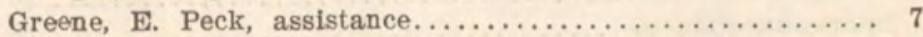

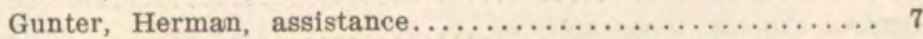

Hamilton County, general water resources of ........... 83

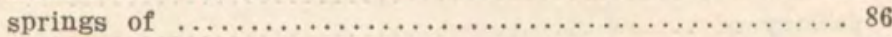

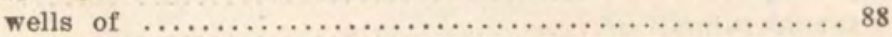

public water supply of $\ldots \ldots \ldots \ldots \ldots \ldots \ldots \ldots \ldots \ldots \ldots$ 
Page.

Hammocks, described $\ldots \ldots \ldots \ldots \ldots \ldots \ldots \ldots \ldots \ldots$

Hawthorne formation $\ldots \ldots \ldots \ldots \ldots \ldots \ldots \ldots \ldots \ldots \ldots \ldots \ldots \ldots$

Hernando County, analyses of spring water from ......... 73

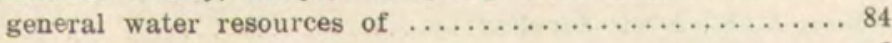

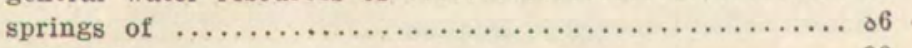

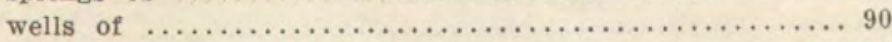

Herzog, H. Jr., water analyses by ................ 79

High Falls, described ........................ 54

Hilgard, cited on evaporation from plants............. 16

Hoskins, cited on depth of underground water.......... 19

Hydrogen sulphide, in underground water............ 19

sulphur deposits formed from....................... 21

amount of, influenced by pressure $\ldots \ldots \ldots \ldots \ldots \ldots \ldots \ldots 22$

Iron removed in solution $\ldots \ldots \ldots \ldots \ldots \ldots \ldots \ldots \ldots \ldots \ldots, 48$

Iron Spring, analysis of water from $\ldots \ldots \ldots \ldots \ldots \ldots \ldots \ldots \ldots \ldots$

Itchatucknee Spring, analysis of water from ........... 72

amount of mineral solids removed by $\ldots \ldots \ldots \ldots \ldots \ldots \ldots 47$

Jacksonville, annual rainfall of $\ldots \ldots \ldots \ldots \ldots \ldots \ldots \ldots \ldots \ldots \ldots$

Jupiter, annual rainfall of $\ldots \ldots \ldots \ldots \ldots \ldots \ldots \ldots \ldots \ldots \ldots \ldots$

Key West, annual rainfall of .............................. 13

King, cited on evaporation from the leaves of plants....... 15

Kinnicutt, L. P., cited on effect of septic tank on bacteria... 66

Lake City, analysis of water from .................... 25

sketch illustrating underground water level at.......... 32

Lakes, drainage of, by wells, ................... 58

Lake County, general water resources of............. 84

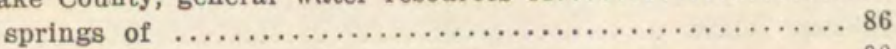

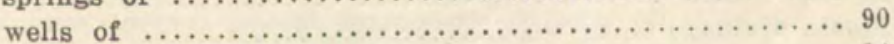

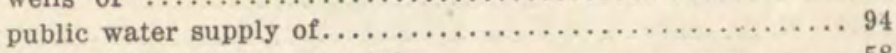

Lake Jackson, drained by sinks $\ldots \ldots \ldots \ldots \ldots \ldots \ldots \ldots \ldots . \ldots \ldots$

LeConte, John, description of Silver Springs........... 36

Levy County, sketch showing water level in ...........4 40

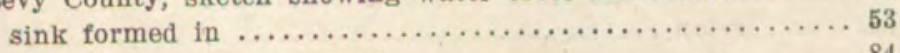

general water resources of $\ldots \ldots \ldots \ldots \ldots \ldots \ldots \ldots \ldots \ldots, 84$

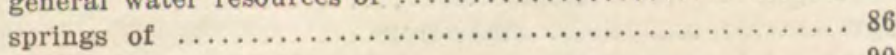

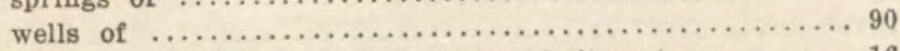

Loughridge, cited on weight of leaves of citrus trees....... 16

Magnesium carbonate, removed in solution............ 48

Magnesia Spring, analysis of water from .............. 70

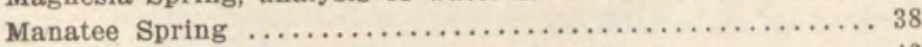

Marion County, sketch showing water level in ......... 40

general water resources of $\ldots \ldots \ldots \ldots \ldots \ldots \ldots \ldots \ldots \ldots . \ldots \ldots$

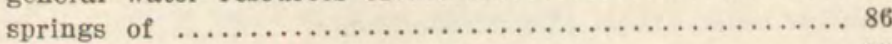

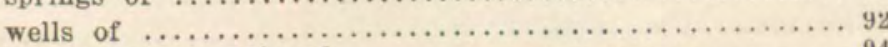

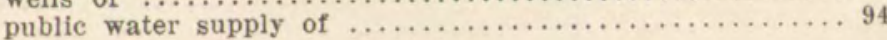


Page.

Matson, George C., cited on inter-connection of cavities..... 66 McCallie, S. W., cited on inter.connection of cavities........ 65

Miller, B. F., levels supplied by ................. 30

Mineral solids removed in solution $\ldots \ldots \ldots \ldots \ldots \ldots \ldots 47,48$

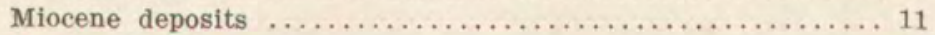

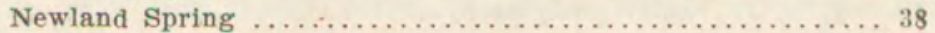

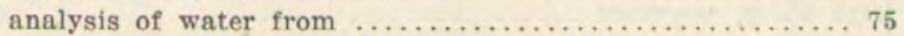

amount of mineral solids removed by .............. 47

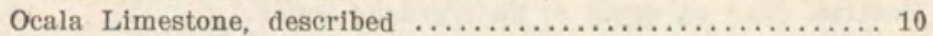

Oligocene limestone, anticlinal structure of ............ 10

Orbitoides, in Vicksburg limestone ................ 10

Organic matter as a source of hydrogen sulphide......... 19

Orlando, drainage by wells at, . . . . . . . . . . . . . 62

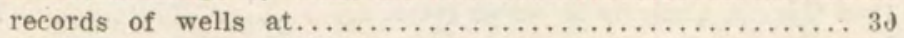

Ostwald, cited on formation of hydrogen sulphide........ 20

Pasco County, general water resources of .............. 85

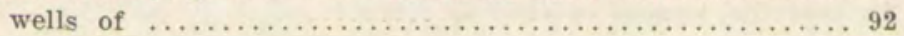

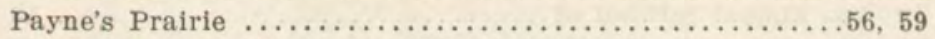

Pellew, C. E., water analysis by ................ 75

Pensacola, annual rainfall of .................... 13

Pearce, James, cited on Alachua sink............... 59

Peas, evaporation from the leaves of ................ 15

Phosphoric acid removed in solution................ 48

Plants, evaporation from the leaves of ............... 13

Pleistocene deposits........................... 11

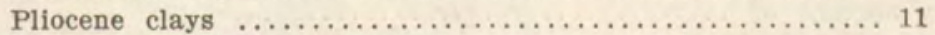

Ponds, drainage of, by wells, . . . . . . . . $5 . \ldots \ldots \ldots \ldots \ldots$

Pratt, N. A., analysis of water by ................ 72

Pratt N. P., analysis by ....................... 73

Quercus cerris, evaporation from the leaves of........... 16

Rainfall entering the earth, estimate of ............ 16

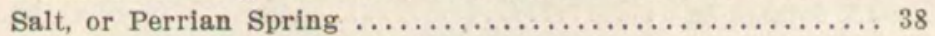

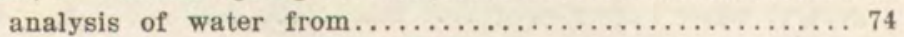

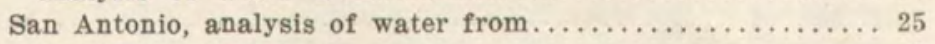

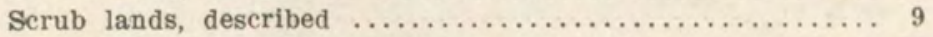

Sellards, E. H., cited on formation of sinks.......... 50

cited on inter-connection of cavities.............. 65

Septic tank, efficiency of ....................... 66

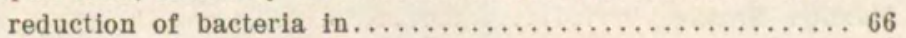

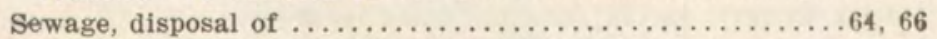

Shaler, N. S., cited on formations of cavities........... 49

Shallow wells, danger of contamination of . . . . . . . . 28

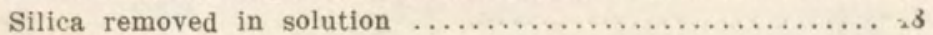


Silver Springs, relation Page.

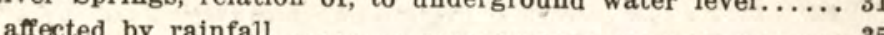
area ${ }^{2}$.

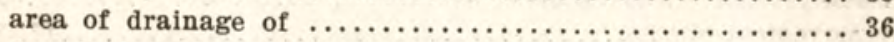

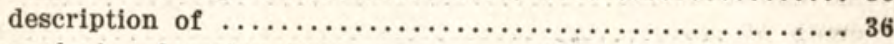
analysis of water from ............................ 74 amount of mineral solids removed by $\ldots \ldots \ldots \ldots \ldots \ldots \ldots 47$

Sink holes, formation of ....................... 50

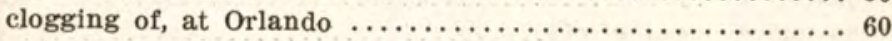

Smith, E. A., cited on Alachua sink ...............6 60

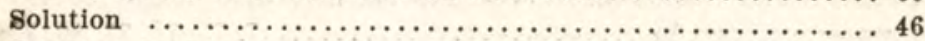

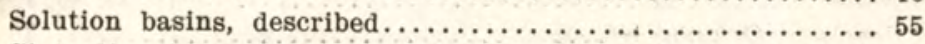

State Chemist, water analyses by $\ldots \ldots \ldots \ldots 73,74,75,76,78,80$

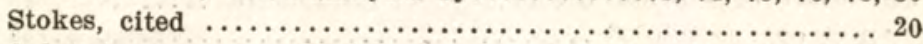

Sulphates as a source of hydrogen sulphides............ 20

Sulphides as a source of hydrogen sulphides........... 20

Sulphur Springs, analysis of water from ............ 71

Sulphur water, not evidence of beds of sulphur.......... 21

Sulphur, occurrence of, in Florida................. 22

Sumter County, general water resources of ............ 85

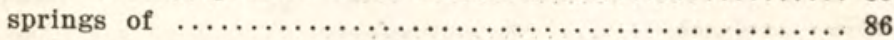

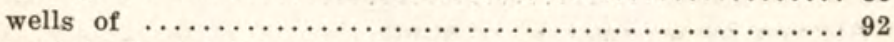

Superintendents city water supply, assistance of......... 8

Surface formation, character of water of,............ 24

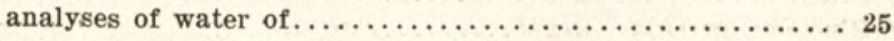

Surface run-off, affected by topography $\ldots \ldots \ldots \ldots \ldots \ldots \ldots \ldots 14$

Suwannee County, general water resources of . . . . . . . . 85

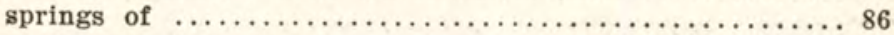

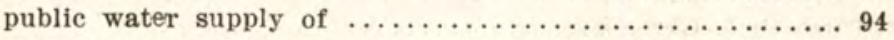

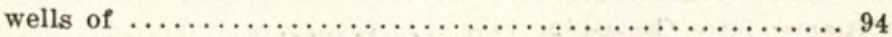

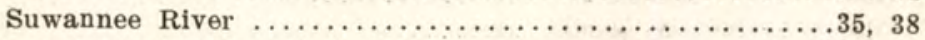

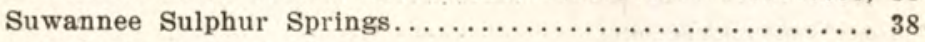

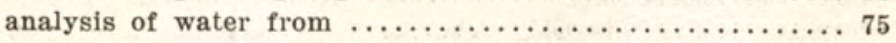
amount of mineral solids removed by ............. 47 correction of solids removed by .................. 102

Swamp lands, drainage of, by wells ............. 58

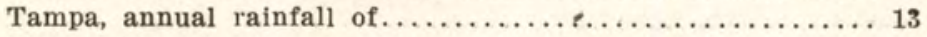

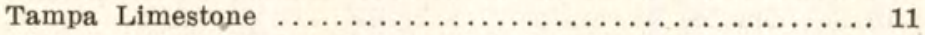

Thorpe, cited on formation of hydrogen sulphide......... 20

Topography, effect of erosion on ................... 46

effected by deposition and replacement............. 56

Typhoid, effect of septic tank on germs of $\ldots \ldots \ldots \ldots \ldots 66$ 
$\begin{array}{ll}\text { Page. } & \text { Page }\end{array}$

Underground water, source of $\ldots \ldots \ldots \ldots \ldots \ldots \ldots \ldots \ldots$

movement of $\ldots \ldots \ldots \ldots \ldots \ldots \ldots \ldots \ldots \ldots \ldots \ldots \ldots \ldots \ldots \ldots \ldots \ldots$

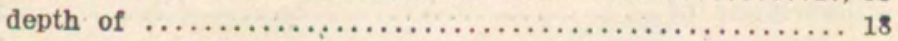

hydrogen sulphide in $\ldots \ldots \ldots \ldots \ldots \ldots \ldots \ldots \ldots \ldots \ldots \ldots \ldots$.

quantity of $\ldots \ldots \ldots \ldots \ldots \ldots \ldots \ldots \ldots \ldots \ldots \ldots \ldots \ldots \ldots \ldots$

quality of $\ldots \ldots \ldots \ldots \ldots \ldots \ldots \ldots \ldots \ldots \ldots \ldots \ldots \ldots \ldots \ldots \ldots \ldots \ldots \ldots, 33$

geological results of $\ldots \ldots \ldots \ldots \ldots \ldots \ldots \ldots \ldots \ldots \ldots \ldots$

United States Geological Survey, Florida investigations by . . . 7 water analyses by, $\ldots \ldots \ldots \ldots \ldots \ldots \ldots \ldots \ldots \ldots \ldots, 75,76,77,80,82$ levels at Orlando by .................. 30

University of Florida, drainage from grounds of . . . . . . 29 sinks on grounds of $\ldots \ldots \ldots \ldots \ldots \ldots \ldots \ldots \ldots \ldots \ldots \ldots \ldots \ldots$

Van Hise, cited on formation of hydrogen sulphide...20, 21, 23

Vicksburg Limestone, described $\ldots \ldots \ldots \ldots \ldots \ldots \ldots \ldots \ldots \ldots \ldots$ surface exposure of . . . . . . . . . . . . . . . . . . 27

source of water of $\ldots \ldots \ldots \ldots \ldots \ldots \ldots \ldots \ldots \ldots \ldots \ldots \ldots$

water level in $\ldots \ldots \ldots \ldots \ldots \ldots \ldots \ldots \ldots \ldots \ldots \ldots \ldots \ldots$

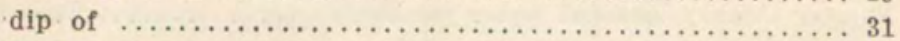

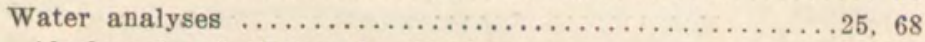

Alachua Ice \& Water Co. Alachua. . . . . . . . . . . . 76

Atlantic Coast Line R. R., Trilby ... . . . . . . . . . . 81

Blue Spring, Juliette $\ldots \ldots \ldots \ldots \ldots \ldots \ldots \ldots \ldots \ldots \ldots \ldots \ldots$

Blue Spring, Otter Creek . . . . . . . . . . . . . . . 73

Boulware Spring, Gainesville................. 70

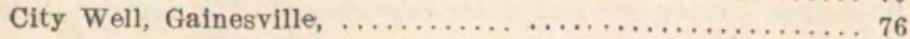

City Well, Lake City, . . . . . . . . . . . . . . . . . 77

City Well, Live Oak, ................... 82

Diamond Ice Co., Gainesville, $\ldots \ldots \ldots \ldots \ldots \ldots \ldots \ldots \ldots$

Dibble \& Earnest, Eustis, .................. 78

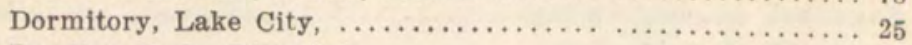

Dowling R. L., Live Oak, .................. 82

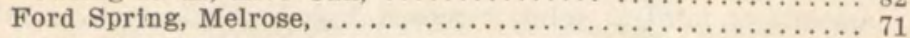

Foster Hall, Lake City, .................... 25

Gaitskill, S. H., MeIntosh, ................. 80

Hensley Place, Lake City, . . . . . . . . . . . . . . . 25

Hoopes Bros. \& Darlington, Brooksville, . . . . . . . . . 78

Ichatueknee Spring, Ft. White, ... . . . . . . . . 72

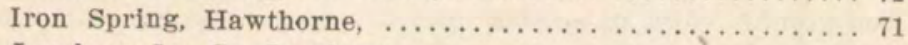

Leesburg Ice Co. Leesburg, $\ldots \ldots \ldots \ldots \ldots \ldots \ldots \ldots \ldots \ldots \ldots$

Magnesia Spring, Hawthorne, ................. 70

Miller residence, Lake City, .................. 25

Muller \& Zinsser, Dade City, ................. 81

Newland Springs, Falmouth, ................ 75 


\title{
ORLANDO PUBLIC LIBRARY SYSTEM
}

\author{
Suwannee Springs- \\ CORRECTION.

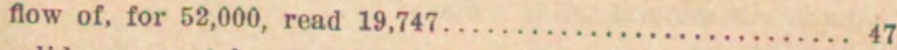 \\ solids removed by, for 207,605 , read $78,816 \ldots \ldots \ldots \ldots \ldots 17$
}


Ocala Water Co., Ocala, $\ldots \ldots \ldots \ldots \ldots \ldots \ldots \ldots \ldots \ldots \ldots, 8, \ldots \ldots \ldots$

Ocala Water Co., Ocala, ......................... 80

Old City Well, Lake City, .......................77

Otter Creek Lumber Co., Otter Creek, ... . . . . . . . . 79

Pearson Oil Well, Crystal River.................... 78

Perrian Spring, Norwalk, $\ldots \ldots \ldots \ldots \ldots \ldots \ldots \ldots \ldots \ldots \ldots \ldots \ldots$

Perry's Corner, Lake City....................... 25

Public Well, Dade City, ....................... 81

Salt Spring, Norwalk, $\ldots \ldots \ldots \ldots \ldots \ldots \ldots \ldots \ldots \ldots \ldots \ldots \ldots \ldots \ldots$

Silver Springs, Ocala, $\ldots \ldots \ldots \ldots \ldots \ldots \ldots \ldots \ldots \ldots \ldots \ldots \ldots \ldots \ldots \ldots$

Sulphur Springs, Hawthorne, $\ldots \ldots \ldots \ldots \ldots \ldots \ldots \ldots \ldots \ldots \ldots$

Suwannee Sulphur Springs, Suwannee.............. 75

Thompson, A. A., Astor..........................78

Weekiwachee Springs, Bayport, $\ldots \ldots \ldots \ldots \ldots \ldots \ldots \ldots \ldots \ldots \ldots \ldots$

White Sulphur Springs, White Springs, . . . . . . . . . 72

Williamson, B. F., Gainesville $\ldots \ldots \ldots \ldots \ldots \ldots \ldots \ldots \ldots \ldots \ldots \ldots$

Williston Mfg. Co., Williston, . . . . . . . . . . . . . . 79

Water level, factors controlling....................... 30

Weekiwachee Spring $\ldots \ldots \ldots \ldots \ldots \ldots \ldots \ldots \ldots \ldots \ldots \ldots, \ldots \ldots \ldots$

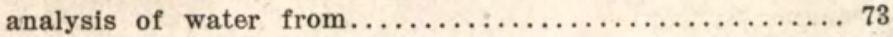

amount of mineral solids removed by ................ 47

Wekiva Spring $\ldots \ldots \ldots \ldots \ldots \ldots \ldots \ldots \ldots \ldots \ldots \ldots \ldots \ldots, \ldots \ldots \ldots$

Wells, water level in ............................. 38

depth of $\ldots \ldots \ldots \ldots \ldots \ldots \ldots \ldots \ldots \ldots \ldots \ldots \ldots \ldots \ldots \ldots \ldots, 39$

cavities reached by $\ldots \ldots \ldots \ldots \ldots \ldots \ldots \ldots \ldots \ldots \ldots \ldots \ldots \ldots \ldots$

drainage of lakes, ponds, and swamp lands by ......... 58

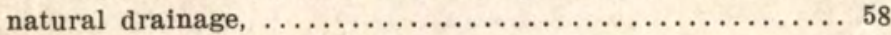

construction of, for drainage purposes............... 61

drainage by, at Orlando, $\ldots \ldots \ldots \ldots \ldots \ldots \ldots \ldots \ldots \ldots \ldots \ldots \ldots \ldots \ldots \ldots$

disposal of sewage by, $\ldots \ldots \ldots \ldots \ldots \ldots \ldots \ldots \ldots \ldots, 64$

Well drillers, assistance of $\ldots \ldots \ldots \ldots \ldots \ldots \ldots \ldots \ldots, 8$

White Sulphur Springs, $\ldots \ldots \ldots \ldots \ldots \ldots \ldots \ldots \ldots \ldots \ldots \ldots \ldots, 38$

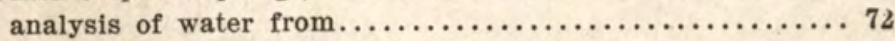

amount of mineral solids removed by $\ldots \ldots \ldots \ldots \ldots \ldots \ldots, 47$ 
